\title{
COMPORTAMENTO DO GLIFOSATO NO SOLO E DESLOCAMENTO MISCÍVEL DE ATRAZINA
}

\author{
FÁBIO PRATA
}

Tese apresentada a Escola Superior de Agricultura "Luiz de Queiroz", Universidade de São Paulo, para obtenção do título de Doutor em Agronomia, Área de Concentração: Solos e Nutrição de Plantas

PIRACICABA

Estado de São Paulo - Brasil

Junho - 2002 


\title{
COMPORTAMENTO DO GLIFOSATO NO SOLO E DELOCAMENTO MISCÍVEL DE ATRAZINA
}

\section{FÁBIO PRATA}

Engenheiro Agrônomo

Orientador: Prof. Dr. ARQUIMEDES LAVORENTI

\begin{abstract}
Tese apresentada a Escola Superior de Agricultura "Luiz de Queiroz”, Universidade de São Paulo, para obtenção do título de Doutor em Agronomia, Área de Concentração: Solos e Nutrição de Plantas
\end{abstract}

\section{PIRACICABA}

Estado de São Paulo - Brasil

Junho - 2002 


\title{
Dados Internacionais de Catalogação na Publicação (CIP)
} DIVISÃO DE BIBLIOTECA E DOCUMENTAÇÃO - ESALQ/USP

\author{
Prata, Fábio \\ Comportamento do glifosa to no solo e deslocamento miscível de \\ atrazina / Fábio Prata. - - Pira cicaba, 2002. \\ $149 \mathrm{p}$. \\ Tese (doutorado) - Escola Superior de Agricultura Luiz de Queiroz, 2002. \\ Bibliografia. \\ 1. Adsorção 2. Fixivia ção 3. Herbicidas 4. Isótopos 5. Q uímic a do solo I. \\ Título
}

CDD 632.954

"Permitida a cópia total ou parcial deste documento, desde que citada a fonte - $\mathrm{O}$ autor" 
à minha mãe, Nadir Corrêa Prata, por todo seu esforço e luta para ter formado um filho, OFEREÇO

ao mestre Arthur Santos Filho, pelo exemplo de vida, DEDICO 


\section{AGRADECIMENTOS}

Agradeço a todos que de alguma forma contribuíram com este trabalho e, em especial:

Ao Professor Dr. Arquimedes Lavorenti, pela orientação, pela confiança, pela oportunidade, pela amizade e pelo companheirismo nos momentos difíceis.

A Dra. Jussara Borges Regitano, pelos ensinamentos, pelas sugestões, pelas correções, pelas críticas sinceras e importantes durante todos os anos de convivência e pela amizade.

Ao Dr. Jan Vanderborght, pelos ensinamentos, pelas sugestões, pelas correções, pela disponibilidade, pela prontidão e pela amizade.

Ao Dr. Valdemar L. Tornisielo, pela oportunidade, pela confiança e pela amizade.

Ao Dr. Peter Burauel, pela oportunidade, pela confiança e pela amizade.

Ao Dr. Harry Vereecken, pelas revisões, pelas sugestões e pela oportunidade.

Ao Dr. Khilian Smith, pelas sugestões, pelas revisões e pela amizade.

À Rosângela Aparecida De Gaspari e a Vanessa Camponez do Brasil Cardinali, pelo auxílio em toda a parte experimental e pela amizade.

Aos Doutores Adriana M. Moreno Pires, Tadeu C. Reis, Robson R.M. Barizon, Genelício C. Rocha, Maria Lúcia A. Silveira, Marcelo E. Alves, Wadson S. D. Rocha, Cristiano A. Andrade, Raider Lund e Luciano Baia Neto, pelas contribuições importantíssimas para a realização deste trabalho: compreensão, estímulo e amizade. 
À Escola Superior de Agricultura "Luiz de Queiroz", ao Centro de Energia Nuclear na Agricultura da USP e ao Forchungszentrum Jülich, pela oportunidade.

À FAPESP, pelo suporte financeiro. 


\section{SUMÁRIO}

Página

RESUMO. ix

SUMMARY $x i$

1 INTRODUÇÃO.

2 REVISÃO DE LITERATURA.

2.1 Propriedades físico-químicas dos pesticidas.

2.1.1 Solubilidade em água $\left(S_{w}\right)$

2.1.2 Pressão de vapor $(P)$.

2.1.3 Coeficiente de partição n-octanol-água $\left(K_{\text {ow }}\right)$.

2.1.4 Constante de ionização ácido/base.

2.1.4.1 Pesticidas com caráter de ácido fraco

2.1.4.2 Pesticidas com caráter de base fraca.

2.1.5 Constante da lei de Henry $\left(\mathrm{K}_{\mathrm{H}}\right)$.

2.2 Retenção de pesticidas no solo

2.2.1 Mecanismos de ligação.

2.2.1.1 Adsorção química..

2.2.1.1.1 Ligações covalentes.

2.2.1.1.2 Ligações de hidrogênio.

2.2.1.2 Adsorção física.

2.2.1.2.1 Forças de van der Waals.

2.2.1.2.2 Ligações iônicas.

2.2.1.3 Interação hidrofóbica.

2.2.2 Resíduo-ligado.

2.3 Transformação de pesticidas no solo. 
2.3.1 Transformações abióticas.

2.3.1.1 Transformação química.....

2.3.1.2 Fotodegradação

2.3.2 Transformação biótica - Biodegradação

2.4 Transporte de pesticidas no solo.

2.4.1 Movimentação no perfil do solo - Lixiviação.

2.4.2 Escorrimento superficial - "Runoff".

2.4.3 Volatilização

3 INFLUÊNCIA DA MATÉRIA ORGÂNICA NA SORÇÃO E DESSORÇÃO DO GLIFOSATO EM SOLOS COM DIFERENTES ATRIBUTOS MINERALÓGICOS.

Resumo.

Summary

3.1 Introdução.

3.2 Material e Métodos.

3.3 Resultados e Discussão.

3.4 Conclusões.

4 SORÇÃO E DESSORÇÃO DO GLIFOSATO EM SOLOS COM NÍVEIS CRESCENTES DE FÓSFORO.

Resumo

Summary.

4.1 Introdução

4.2 Material e Métodos

4.3 Resultados e Discussão.

4.4 Conclusões.

5 COMPORTAMENTO DO GLIFOSATO EM UM LATOSSOLO VERMELHO SOB PLANTIO DIRETO E CONVENCIONAL.

Resumo. 
5.1 Introdução.

5.2 Material e Métodos.

5.3 Resultados e Discussão

5.4 Conclusões

6 DESLOCAMENTO MISCIVEL, SORÇÃO E DESSORÇÃO DE ATRAZINA EM UM LATOSSOLO VERMELHO SOB PLANTIO DIRETO E CONVENCIONAL.

Resumo.

Summary.

6.1 Introdução.

6.1.1 Teoria dos modelos de transporte em estudos de deslocamento miscível.......

6.1.1.1 Modelo de transporte de solutos baseado na equação de conveç̧ãodispersão (ECD) para solutos que apresentam sorção em equilíbrio.

6.1.1.2 Modelo de transporte de solutos baseado na equação de conveç̧ãodispersão (ECD) para solutos que não apresentam sorção em equilibrio.

6.1.1.2.1 Modelo "Two-site/two-region" para transporte de solutos no solo.

6.2 Material e Métodos.

6.2.1 Solo.

6.2.2 Pesticida e padrões analíticos

6.2.3 Experimento de deslocamento miscível

6.2.4 Experimento de sorção/dessorção.

6.2.5 Análise dos dados.

6.3 Resultados e Discussão

6.3.1 Deslocamento miscível.

6.3.2 Sorção e dessorção.

6.4 Conclusões. 


\title{
COMPORTAMENTO DO GLIFOSATO NO SOLO E DESLOCAMENTO MISCÍVEL DE ATRAZINA
}

\author{
Autor: FÁBIO PRATA \\ Orientador: Prof. Dr. ARQUIMEDES LAVORENTI
}

\section{RESUMO}

O objetivo desse trabalho foi estudar o comportamento do herbicida glifosato em solos sob diferentes aspectos e o deslocamento miscível da atrazina, empregando a modelagem matemática na determinação de parâmetros de sorção e transporte. Para tal, foram conduzidos vários experimentos com o glifosato, no Laboratório de Ecotoxicologia do Centro de Energia Nuclear na Agricultura (CENA/USP), sendo os ensaios referentes a atrazina conduzidos no Forchungszentrum Jülich, Jülich, Alemanha. No primeiro capítulo foi avaliada a influência da matéria orgânica na sorção e dessorção do glifosato em três solos brasileiros com diferentes atributos mineralógicos. A base deste estudo foi o estudo de isotermas de sorção, pela técnica "batch", em amostras de solo com e sem oxidação da matéria orgânica. No segundo capítulo, foi verificada a extensão do efeito de níveis crescentes de fósforo no solo na sorção e dessorção do glifosato. No capítulo terceiro foi estudado o comportamento do glifosato num caso especial: um solo mantido há 23 anos sob plantio direto ou plantio convencional. Para tanto, foram conduzidos 4 experimentos, nos quais foram verificados a mineralização e a formação de resíduo-ligado, a cinética de sorção e dessorção, a sorção/dessorção e a fitodisponibilidade do glifosato, através de um teste biológico. No último capítulo estudou-se o deslocamento miscível da atrazina em colunas deformadas de solo, empregando-se estudo de traçador $\left(\mathrm{Br}^{-}\right)$e modelagem matemática para a determinação de parâmetros de sorção e de transporte do herbicida. Aos resultados de deslocamento do traçador foi aplicado o modelo de transporte baseado na equação de convecçãodispersão, considerando o equilíbrio de sorção. Para o deslocamento da atrazina foi 
utilizado o modelo matemático "two-site", também baseado na equação de convecçãodispersão, entretanto, considerando o não-equilíbrio químico de sorção. Neste capítulo também foi avaliada a sorção/dessorção da atrazina pela técnica "batch". Optourse por utilizar a atrazina no estudo de deslocamento miscível e não o glifosato, pelo fato do segundo não apresentar potencial de mobilidade vertical no solo. Concluiu-se que a sorção do glifosato é instantânea, extremamente elevada e está relacionada, principalmente, a fração mineral do solo, sendo que a matéria orgânica desempenha papel secundário no caso de solos oxídicos. O glifosato compete com os fosfatos inorgânicos pelos sítios de sorção no solo, entretanto, esta competição somente passa a ser importante para níveis de $\mathrm{P}$ extremamente elevados, os quais não são atingidos em condições reais de campo. O glifosato não pode ser extraído do solo em condições normais de solos agricultáveis, permanecendo na forma de resíduo-ligado. O sistema de plantio direto pode contribuir com a aceleração da mineralização do glifosato no solo, todavia, sua meia-vida é baixa e está relacionada à formação de resíduo-ligado, não tendo apresentado problemas de fitotoxidez nos testes realizados. Com relação ao deslocamento da atrazina, concluiu-se que a molécula apresenta potencial de lixiviação no solo, sendo que este potencial é dependente da sorção nos sítios em equilíbrio e em não-equilíbrio com a solução do solo. No entanto, a sorção irreversível foi mais importante que a sorção "reversível" em ambos os sítios em equilíbrio e não-equilíbrio. Os modelos de transporte foram ajustados com sucesso aos dados de deslocamento miscível do traçador e da atrazina. Todavia, o modelo "two-site" superestimou a sorção irreversível (formação de resíduo-ligado), para a concentração residente na coluna. O modelo de transporte "two-site", ajustado aos dados de deslocamento miscível da atrazina, previu coeficientes de sorção linear semelhantes aos gerados pelo método "batch", o que não foi verdade para a dessorção. 


\title{
GLYPHOSATE BEHAVIOR IN SOIL AND MISCIBLE DISPLACEMENT OF ATRAZINE
}

\author{
Author: FÁBIO PRATA \\ Adviser: Prof. Dr. ARQUIMEDES LAVORENTI
}

\section{SUMMARY}

The aim of this research was to evaluate the glyphosate behavior in soils under different aspects, as well as the miscible displacement of atrazine, using mathematical modeling to determine sorption and transport parameters. The experiments about glyphosate were carried out at Laboratory of Ecotoxicology of the Centro de Energia Nuclear na Agricultura (CENA/USP), Piracicaba, SP (Brazil), and the studies about atrazine at Forchungszentrum Jülich, Jülich, Germany. In the first chapter we evaluated the effects of soil organic matter on the sorption and desorption of glyphosate in three soils with different mineralogical attributes. This was an isotherm batch experiment in soil samples with or without organic matter. In the second chapter we evaluated the effects of the increasing rates of phosphorus on the sorption and desorption of glyphosate. In the third chapter we studied the glyphosate behavior as an especial situation: An Brazilian Oxisol collected from both a no-till and a conventional management soil systems. Both agricultural systems had been in production for 23 years. Glyphosate mineralization, its bound-residue forms, sorption and desorption batch kinetics, sorption/desorption batch isotherms experiments, and glyphosate phythoavailability (to Panicum maximum) were determined. In the last chapter, the miscible displacement and the sorption/desorption of atrazine. In order to fit the atrazine breakthrough curves, to evaluate the contribution of sorption on the atrazine leaching (equilibrium vs nonequilibrium sorption; reversible vs irreversible sorption), we employed a tracer study $\left(\mathrm{Br}^{-}\right)$and used mathematical modeling. We fitted the $\mathrm{Br}^{-}$ 
displacement with an equilibrium convective dispersive transport model, and atrazine displacement with two-site chemical nonequilibrium dispersive convective transport model. The atrazine was employed in this study, instead glyphosate, because the second one does not present leaching potential. We concluded the glyphosate sorption is instantaneous, extremely high and presents relationship, mainly, with the mineral soil fraction. Soil organic matter only plays a secondary role for oxidic soils. Glyphosate competes with inorganic phosphates for specific sorption sites, but this competition becomes important when phosphorus is a rates higher than the normally seen in real field conditions. The glyphosate can not be extracted from the soil, under normal conditions of agricultural soils, remaining as bound-residues. The no-till system may contribute to the enhancement of glyphosate mineralization in the soil. However, its half-life is low and is related with the bound-residue formation. Glyphosate did not present phytotoxicity in the specific studied. About atrazine displacement, we concluded the atrazine presented a potential leaching. This potential was dependent of equilibrium and nonequilibrium sorption sites. However, irreversible sorption was more important than "reversible" sorption in equilibrium and nonequilibrium sites. Both equilibrium and nonequilibrium models successfully fitted the $\mathrm{Br}^{-}$and atrazine breakthrough curves, respectively, for both management systems. However, the two-site nonequilibrium model overestimated the irreversible sorption (bound-residue formation) for resident concentration of atrazine within soil column. The two-site nonequilibrium transport model predicted partition coefficients for sorption very similar to these measured in the sorption batch experiment. This was not true for desorption data. 


\section{INTRODUÇÃO}

A descoberta do poder de algumas substâncias organossintéticas para o controle de agentes indesejáveis ou nocivos como insetos, fungos, plantas daninhas etc., proporcionou a expansão das áreas cultivadas e o aumento da produção de alimentos em todo mundo. Em menos de quarenta anos, esses produtos químicos de utilização agronômica, tornaram-se os insumos mais utilizados na produção agrícola de larga escala, tendo seu uso intensificado em meados dos anos 70, com a chamada Revolução Verde. Atualmente, as vendas de produtos fitossanitários no mundo chegam à cerca de 40 bilhões de dólares (Foloni, 2000), sendo que os herbicidas representam a maior parte desse mercado (Conceição, 2000).

O interesse e a preocupação de cientistas do solo com o uso intenso dessas moléculas se deu tão logo elas começaram a serem utilizadas. Em 1960, já havia sessões especiais em simpósios, as quais tratavam do comportamento de pesticidas no ambiente, como as dos encontros anuais da "American Society of Agronomy" e "Soil Science Society of America". Uma publicação clássica desse período foi "Pesticides and their effects on soils and water" (Breth, 1966). Posteriormente, Guenzi (1974) editou uma coletânea de revisões sobre vários aspectos referentes ao comportamento de pesticidas no ambiente a qual foi publicada pela "Soil Science Society of America", sendo intitulada "Pesticides in soil and water". Deste ponto em diante, várias revisões da "Soil Science Society of America" têm abordado o comportamento dos pesticidas no solo, destacando-se: "Reactions and movement of organic chemicals in soils" (Sawhney \& Brown, 1989), "Pesticides in the soil environment: Processes, impacts, and modeling" (Cheng, 1990) e "Sorption and degradation of pesticides and organic chemicals in soil" 
(Linn, 1993). No Brasil, tem sido muito escasso o número de estudos nesta área, sendo pequeno também o número de publicações científicas disponíveis.

Quando as moléculas de um determinado pesticida são aplicadas no ambiente, seja da forma que for essa aplicação, o destino final, na maioria dos casos, será o solo. Já no solo, as moléculas podem seguir diferentes rotas, isto é, podem ser retidas aos colóides minerais e orgânicos e a partir daí passarem para formas indisponíveis, ou serem novamente liberadas à solução do solo, processo conhecido como dessorção. As moléculas também podem ser transformadas em outras, chamadas de produtos de tranformação ou metabólitos. O ponto final dessa transformação, naturalmente para moléculas que atingem esta fase, é a mineralização à $\mathrm{CO}_{2}, \mathrm{H}_{2} \mathrm{O}$ e íons minerais, o que se dá, fundamentalmente, via microrganismos. Se as moléculas se encontram na solução do solo, elas podem ser absorvidas por raízes de plantas, ou serem lixiviadas para camadas subsuperficiais do perfil do solo ou sofrerem escorrimento superficial, ou ainda serem volatilizadas. Tudo isso ocorre no solo simultaneamente, em intensidades diferentes, e depende das propriedades físico-químicas da molécula, propriedades físicas, químicas e biológicas do solo e dos fatores climáticos.

Com o advento das plantas geneticamente alteradas, muitos conceitos relacionados ao sistema solo-planta devem ser repensados cautelosamente para que erros futuros não sejam cometidos. Atualmente, um dos maiores exemplos dessa tecnologia talvez seja o das variedades de soja (Glycine max L.) resistentes ao herbicida glifosato. $\mathrm{Na}$ Argentina e nos Estados Unidos estas variedades já vem sendo cultivadas com relativo sucesso, todavia, ainda encontram-se em fase de registro no Brasil. Existem ainda outras plantas que já foram alteradas geneticamente e também possuem resistência ao glifosato, como o milho, o algodão e a canola.

O glifosato [n-(fosfonometil)glicina)] é um herbicida pós-emergente, não seletivo em condições normais. De modo geral, apenas plantas geneticamente alteradas, com a resistência induzida, apresentam seletividade ao glifosato, que, atualmente, é o herbicida mais vendido no mundo (Mendelson, 1998). No Brasil, o glifosato tem sido amplamente utilizado, principalmente como dessecante em cultivos sob plantio direto, 
nas entrelinhas de culturas e na eliminação de plantas daninhas de ambientes aquáticos (Rodrigues \& Almeida, 1995).

Considerando-se que o glifosato apresenta baixo custo relativo e excelente eficiência agronômica A introdução de variedades resistentes, provavelmente, resultará no aumento das taxas de aplicação desta molécula numa mesma área. Assim, os cuidados relacionados à possibilidade de contaminação do ambiente com esta molécula devem ser estudados cautelosamente.

O comportamento do glifosato no solo tem sido tema de várias pesquisas (Nomura \& Hilton, 1977; Glass, 1987; Miles \& Moye, 1988; Gerritse et al., 1996; Cheah et al., 1997; Prata et al., 2000b; Jonge et al. 2001). De forma geral, essas pesquisas caracterizam o herbicida pela sua elevada capacidade de sorção, a qual impede sua degradação na solução do solo. Isso faz com que o glifosato permaneça no solo como resíduo-ligado. Entretanto, a maior parte desses trabalhos foi realizada sob condições de solo e clima contrastantes aos encontrados no Brasil. Com isso, é de fundamental importância que o comportamento do glifosato no solo, em condições de clima tropical, seja avaliado sob diferentes aspectos, aspectos estes que constituem os três primeiros capítulos desta tese.

A dificuldade na condução de experimentos relacionados ao comportamento de pesticidas no ambiente, principalmente pelo elevado custo das pesquisas, tem feito da modelagem matemática uma ferramenta muito importante na previsão do potencial de transporte de muitas moléculas no solo. Adicionalmente, determinados parâmetros de transporte, e até mesmo parâmetros relacionados à sorção de pesticidas, não podem ser determinados sem a utilização dos modelos matemáticos de transporte. Neste contexto, no último capítulo desta tese foi estudado o deslocamento miscível da atrazina [2-cloro4-(etilamino)-6-(isopropilamino)-s-triazina], com aplicação de modelagem matemática para obtenção de parâmetros de transporte.

O herbicida atrazina foi empregado neste estudo pelo fato de ser uma molécula das mais utilizadas no mundo (Lerch et al., 1999) e, principalmente, por apresentar baixos valores de coeficiente de sorção (entre 0,4 e 4,5 $\mathrm{L} \mathrm{kg}^{-1}$ ) e meia-vida que pode ser 
superior a 100 dias, dependendo do tipo de solo (Montgomery, 1997), o que a sugere um potencial de mobilidade.

Vários estudos de monitoramento ambiental, em áreas norte-americanas, têm mostrado a presença da atrazina e de seus metabólitos; desetilatrazina (DEA) e desisopropilatrazina (DIA), em cursos de água tanto superficiais como subsuperficiais (Thurman et al., 1991; Thurman et al., 1994; Cai et al., 1994; Lerch et al., 1998). No entanto, resultados desta natureza são praticamente inexistentes para as condições brasileiras.

Neste sentido, o objetivo principal desta tese foi de estudar o comportamento do glifosato, sob vários aspectos, em solos brasileiros, assim com estudar o deslocamento miscível da atrazina com a utilização de modelos matemáticos de transporte. 


\section{REVISÃO DE LITERATURA}

\subsection{Propriedades físico-químicas dos pesticidas}

Cada pesticida, em virtude dos átomos que o compõe, seu número e da maneira como eles são arranjados na estrutura química, possui uma série específica de propriedades físico-químicas.

As principais propriedades físico-químicas de um pesticida, relacionadas a seu comportamento ambiental, são: solubilidade em água $\left(S_{\mathrm{W}}\right)$, pressão de vapor $(P)$, coeficiente de partição n-octanolágua $\left(K_{\mathrm{ow}}\right)$, constante de equilíbrio de ionização ácido $\left(\mathrm{p} K_{\mathrm{a}}\right)$ ou base $\left(\mathrm{p} K_{\mathrm{b}}\right)$ e constante da lei de Henry $\left(K_{\mathrm{H}}\right)$. Essas propriedades químicas são normalmente determinadas em laboratório sob condições controladas e por métodos muito bem conhecidos.

\subsubsection{Solubilidade em água $\left(S_{\mathrm{w}}\right)$}

A solubilidade de um pesticida em água refere-se à concentração máxima da molécula (pura) que pode ser solubilizada em água, a uma determinada temperatura. Acima desta concentração, duas fases distintas existirão. Dos vários parâmetros que afetam o destino de pesticidas no solo, a $S_{\mathrm{w}}$ é um dos mais importantes. Pesticidas altamente solúveis, com algumas exceções como, por exemplo, o glifosato (Piccolo et al., 1994), tendem a apresentar baixos coeficientes de sorção em solos e sedimentos, em função da baixa afinidade aos colóides do solo, principalmente os colóides orgânicos. Kawamoto \& Urano (1989) obtiveram a seguinte relação entre $S_{\mathrm{w}}$ e $K_{\mathrm{oc}}$ (constante que mede a afinidade do pesticida com o carbono orgânico) para organoclorados: $\log K_{\mathrm{oc}}=$ 0,464 $\log S_{\mathrm{w}}+3,788$, mostrando que quanto maior a solubilidade em água, menor a afinidade da molécula com a matéria orgânica do solo. Outros meios de transformação 
dos pesticidas no solo, como a fotólise, a hidrólise e a oxidação também são afetadas pela extensão da $S_{\mathrm{w}}$ (Wolfe et al., 1990).

\subsubsection{Pressão de vapor $(P)$}

A pressão de vapor de um pesticida é uma medida da tendência de volatilização no seu estado normal puro, sendo função direta da temperatura. No entanto, o valor de $P$ não indica em qual taxa o pesticida se volatilizará.

De forma geral, pesticidas com valores de $P>10^{-2} \mathrm{~mm} \mathrm{Hg}$ são considerados muito voláteis à temperatura ambiente; $10^{-4} \leq P \leq 10^{-3}$, medianamente voláteis; $10^{-7} \leq P$ $\leq 10^{-5}$, pouco voláteis e $P<10^{-8}$, não voláteis (Deuber, 1992).

Os herbicidas do grupo dos tiocarbamatos, como o EPTC, verno late e butilate, são exemplos de moléculas muito voláteis, as quais requerem incorporação imediata no solo. Outro exemplo clássico é a trifluralina, que além de volátil é também fotossensível, sendo assim recomendada sua aplicação apenas em pré-plantio incorporado para a grande maioria de suas formulações (Hornsby et al., 1995).

\subsubsection{Coeficiente de partição n-octanol-água $\left(K_{0 w}\right)$}

O coeficiente de partição n-octanol-água é definido como a relação da concentração de um pesticida na fase de n-octanol saturado em água e sua concentração na fase aquosa saturada em n-octanol. Valores de $K_{\text {ow }}$ não tem unidade e são expressos, normalmente, na forma logarítmica $\left(\log K_{\mathrm{ow}}\right)$.

$$
K_{\text {ow }}=\frac{\text { Concentração na fase n-octanol }}{\text { Concentração na fase aquosa }}
$$

O coeficiente de partição n-octanolágua é um parâmetro muito importante nos estudos relacionados ao destino de moléculas orgânicas no ambiente. Observourse que ele está relacionado com a solubilidade em água (Dai et al., 1998), com o coeficiente de partição solo/solução (Chiou, et al. 1979; Kawamoto \& Urano, 1989), com o fator de bioconcentração para a vida aquática (Montgomery, 1997; Lu et al., 1999), com o fator de retenção em cromatografia líquida de fase reversa (Woodburn et al., 1992), com o 
tempo de retenção em cromatografia líquida de alta performance-HPLC (Burkhard \& Kuehl, 1986) e com muitos outros indicadores de interesse ambiental e metodológico. Por exemplo, o transporte de uma molécula de pesticida no solo depende, além de outros fatores, do balanço entre suas propriedades hidrofílicas e lipofílicas. Este balanço é estimado, normalmente, através do uso do $K_{\text {ow }}$.

Pesticidas lipofílicos, com valores de $\log K_{\text {ow }}>4,0$, tendem a se acumular nos materiais lipídicos, assim como na fração orgânica do solo. Servem como exemplo o clorpirifos, o heptacloro e a trifluralina (Montgomery, 1997). Pesticidas hidrofílicos, com valores de $\log K_{\mathrm{ow}}<1,0$, são mais solúveis em água e, portanto, não são atraídos aos materiais lipídicos, apresentando deste modo baixa sorção ao solo/sedimento e baixa bioconcentração em relação à vida aquática. São exemplos o picloran, o dicamba e o dalapon-sódico (Farmer \& Aochi, 1974; Grover, 1977; Montgomery, 1997). Para compostos ionizáveis, os valores de $K_{\text {ow }}$ dependem do $\mathrm{pH}$ e, portanto, esses valores devem sempre acompanhar os valores de $K_{\text {ow }}$.

\subsubsection{Constante de ionização ácido/base}

A constante de ionização ácido/base $\left(K_{\mathrm{a}}\right.$ ou $K_{\mathrm{b}}$, ) é empregada para moléculas que possuem caráter de ácido fraco ou base fraca, respectivamente, e representa a maior ou menor tendência (força) do pesticida em se ionizar. Os valores dessas constantes indicam dentro de qual faixa de $\mathrm{pH}$ da solução do solo o pesticida se ionizará. Isso é muito importante, pois as formas ionizadas de pesticidas se comportam diferentemente das não ionizadas (neutras).

Os valores de $\mathrm{p} K$ (potencial da constante de ionização ácido/base) representam uma forma logaritimizada de $K(\mathrm{pK}=-\log \mathrm{K})$ e têm sido preferidos em relação aos valores das constantes nos estudos de comportamento de pesticidas no solo.

\subsubsection{Pesticidas com caráter de ácido fraco}

Pesticidas ácidos são aqueles cujas formas moleculares (neutras) são capazes de doar um ou mais prótons e formar íons carregados negativamente. Esta definição está restrita apenas à definição clássica de Brönsted-Lowry, a qual tem sido utilizada para 
substâncias presentes em solução aquosa, e se adapta perfeitamente aos pesticidas na solução do solo.

A reação de equilíbrio de um pesticida ácido e a constante de equilíbrio a ela associada $\left(K_{\mathrm{a}}\right)$, são definidas como (Lavorenti, 1999):

$$
\mathrm{HA}+\mathrm{H}_{2} \mathrm{O} \Leftrightarrow \mathrm{A}^{-}+\mathrm{H}_{3} \mathrm{O}^{+}
$$

Aplicando a lei da ação das massas ao equilíbrio da reação (eq. 2), tem-se:

$$
K_{a}=\frac{\left[A^{-} \backslash \mathrm{H}_{3} \mathrm{O}^{+}\right]}{[\mathrm{HA}]\left[\mathrm{H}_{2} \mathrm{O}\right]}
$$

em que, $\mathrm{HA}, \mathrm{A}^{-}$, e $\mathrm{H}_{3} \mathrm{O}^{+}\left(=\mathrm{H}^{+}\right)$representam o pesticida não ionizado, pesticida ionizado e o íon hidroxônio, respectivamente, e os colchetes indicam as concentrações das espécies químicas envolvidas. Em soluções diluídas, como é o caso da solução do solo, a atividade iônica pode ser substituída por concentração. Em analogia ao índice pH (= $\left.\log \left[\mathrm{H}^{+}\right]\right)$, o valor de $\mathrm{p} K_{\mathrm{a}}$ pode ser definido como:

$$
p K_{a}=\log \frac{1}{\left[K_{a}\right]}
$$

Quanto maior for o valor do $\mathrm{p} K_{\mathrm{a}}$ do pesticida, mais fraca é a sua força ácida. Isto é, menor a tendência da reação (eq. 2) se deslocar para a direita e menor a chance do pesticida ficar aniônico.

Substituindo (eq. 3) em (eq. 4), sabendo que $\left[\mathrm{H}_{2} \mathrm{O}\right]=1$ por definição e fazendo os desdobramentos necessários tem-se que:

$$
\begin{gathered}
p K_{a}=\log \frac{[H A]}{\left.\left[A^{-}\right] H^{+}\right]} \\
p K_{a}=\log [H A]-\log \left[A^{-}\right]-\log \left[H^{+}\right] \\
p K_{a}=\log [H A]-\log \left[A^{-}\right]+p H \\
p K_{a}-p H=\log \frac{[H A]}{\left[A^{-}\right]}
\end{gathered}
$$


A equação (8) serve de base para o cálculo das concentrações do pesticida ácido nas formas não dissociada (molecular ou neutra) e dissociada (aniônica ou deprotonada):

i) $\quad \operatorname{Se~o~pH~(solução~do~solo)~}=\mathrm{p} K_{\mathrm{a} \text { (pesticida) }}$, então $[\mathrm{HA}]=\left[\mathrm{A}^{-}\right]$

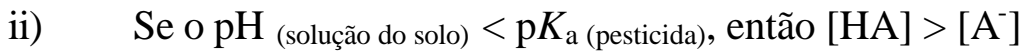

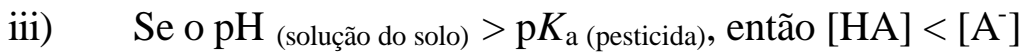

Quando o valor do $\mathrm{pH}$ do meio for duas ou mais unidades superior ao valor do $\mathrm{p} K_{\mathrm{a}}$ do pesticida (consideração iii), pode-se verificar, pela equação (8), que praticamente só existirá a forma aniônica da molécula, a qual por sua vez pode apresentar, normalmente, maior mobilidade no perfil do solo.

\subsubsection{Pesticidas com caráter de base fraca}

Pesticidas básicos são aqueles cujas formas neutras (moleculares) são capazes de receber um ou mais prótons e formar íons carregados positivamente.

A reação de equilíbrio de um pesticida básico e a constante de equilíbrio a ela associada $\left(K_{\mathrm{b}}\right)$, são definidas como (Lavorenti, 1999):

$$
\mathrm{B}+\mathrm{H}_{2} \mathrm{O} \Leftrightarrow \mathrm{BH}^{+}+\mathrm{OH}^{-}
$$

Aplicando a lei da ação das massas ao equilíbrio da reação (eq. 9), tem-se:

$$
K_{b}=\frac{\left[B H^{+}\left[O H^{-}\right]\right.}{[B]\left[H_{2} O\right]}
$$

em que $\mathrm{B}, \mathrm{OH}$, e $\mathrm{BH}^{+}$representam o pesticida não ionizado, o íon hidroxila e o pesticida ionizado (associado, protonado), respectivamente. A exemplo do caso dos pesticidas ácidos:

$$
p K_{b}=\log \frac{1}{K_{b}}
$$


Quanto maior for o valor do $\mathrm{p} K_{\mathrm{b}}$ do pesticida, mais fraca é a sua força básica. Isto é, menor a tendência da reação (eq. 9) se deslocar para a direita e menor a chance do pesticida ficar catiônico.

Substituindo (eq. 10) em (eq. 11), sabendo que $\left[\mathrm{H}_{2} \mathrm{O}\right]=1$ por definição, e fazendo os desdobramentos necessários, tem-se que:

$$
\begin{gathered}
p K_{b}=\log \frac{[B]}{\left.B H^{+}\right]\left[O H^{-}\right]} \\
p K_{b}=\log [B]-\log \left[B H^{+}\right]-\log \left[O H^{-}\right] \\
p O H=-\log \left[O H^{-}\right]=14-p H \\
p K_{b}=\log [B]-\log \left[B H^{+}\right]+14-p H \\
p K_{b}+(p H-14)=\log \frac{[B]}{\left.B H^{+}\right]}
\end{gathered}
$$

A equação (16) serve de base para o cálculo das concentrações do pesticida básico nas formas não dissociada (molecular) e associada (catiônica). Considerações a respeito da equação (16):

i) $\quad \mathrm{Se} o \mathrm{pH}$ (solução do solo) $=\mathrm{p} K_{\mathrm{b}}$ (pesticida), há uma tendência do pesticida se apresentar com uma concentração maior na forma catiônica em $\mathrm{pH}=$ $\mathrm{p} K_{\mathrm{b}} \leq 6$ ou na forma molecular em $\mathrm{pH}=\mathrm{p} K_{\mathrm{b}} \geq 8$. As concentrações de ambas as formas serão iguais apenas em $\mathrm{pH}=7$.

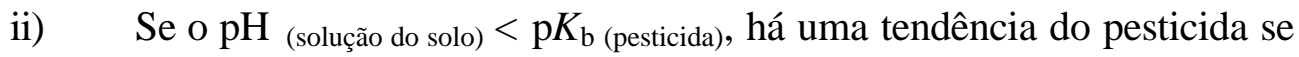
apresentar com uma concentração maior na forma catiônica em $\mathrm{pH} \leq$ 5 ou na forma molecular em $\mathrm{pH} \geq 7$.

iii) $\quad \mathrm{Se} o \mathrm{pH}$ (solução do solo) $>\mathrm{p} K_{\mathrm{b}}$ (pesticida), há uma tendência do pesticida se apresentar com concentração maior na forma catiônica em $\mathrm{pH} \leq 7$. Isto ocorre principalmente com uma ou mais unidades de $\mathrm{pH}$ acima do valor do $\mathrm{p} K_{\mathrm{b}}$ do pesticida básico. Nestas condições, o pesticida tem grandes probabilidades de ficar sorvido aos componentes do solo e não ser transportado para outras partes do ambiente. Em valores de 
$\mathrm{pH} \geq 8$ pode haver um equilíbrio entre as concentrações das formas catiônicas e moleculares e com tendências a predominarem as concentrações das formas moleculares à medida que o $\mathrm{pH}$ aumenta, observando sempre valores de $\mathrm{p} K_{\mathrm{b}}$ menores que o $\mathrm{pH}$ da solução do solo.

Uma vez que é comum o uso de valores de $\mathrm{p} K_{\mathrm{a}}$, indistintamente para pesticidas ácidos ou básicos, deve-se considerar que a espécie química $\mathrm{BH}^{+}$, produto da reação (eq. 9), é um ácido conjugado do pesticida básico, B, tem-se que:

$$
\mathrm{BH}^{+}+\mathrm{H}_{2} \mathrm{O} \Leftrightarrow \mathrm{B}+\mathrm{H}_{3} \mathrm{O}^{+}
$$

Aplicando a lei da ação das massas ao equilíbrio da reação (eq. 17), tem-se:

$$
K_{a^{\prime}}=\frac{[B]\left[\mathrm{H}_{3} \mathrm{O}^{+}\right]}{\left[B H^{+}\right]\left[\mathrm{H}_{2} \mathrm{O}\right]}
$$

seguindo o raciocínio anterior:

$$
\begin{gathered}
p K_{a^{\prime}}=\log \frac{1}{\left[K_{a^{\prime}}\right]} \\
p K_{a^{\prime}}=\log \frac{\left[B H^{+}\right]}{[B]\left[H^{+}\right]} \\
p K_{a^{\prime}}=\log \left[B H^{+}\right]-\log [B]-\log \left[H^{+}\right] \\
p K_{a^{\prime}}=\log \left[B H^{+}\right]-\log [B]+p H \\
p K_{a^{\prime}}-p H=\log \frac{\left[B H^{+}\right]}{[B]}
\end{gathered}
$$

A equação (23) serve de base para calcular as concentrações do pesticida básico nas formas não dissociada (molecular) e associada (catiônica). O $K_{\mathrm{a}}$, e $\mathrm{p} K_{\mathrm{a}}$, são aqui utilizados para pesticidas básicos para diferenciar do $K_{\mathrm{a}} \mathrm{e}$ p $K_{\mathrm{a}}$ dos pesticidas ácidos. Considerações a respeito da equação (23):

i) $\quad \mathrm{Se} \mathrm{o} \mathrm{pH}($ solução do solo $)=\mathrm{p}_{\mathrm{a}}$ (pesticida), então $\left[\mathrm{BH}^{+}\right]=[\mathrm{B}]$. 
ii) $\quad \mathrm{Se} \mathrm{o} \mathrm{pH}$ (solução do solo) $<\mathrm{p} K_{\mathrm{a}}$ (pesticida), então $\left[\mathrm{BH}^{+}\right]>[\mathrm{B}]$.

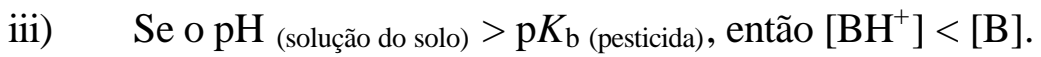

\subsubsection{Constante da lei de Henry $\left(K_{H}\right)$}

A constante da lei de Henry refere-se ao coeficiente de partição ar-líquido ou vapor-líquido e é definida pela equação:

$$
K_{H}=\frac{P_{i}}{C_{i}}
$$

na qual, $P_{\mathrm{i}}$ representa a pressão parcial na interface ar-água e $\mathrm{C}_{\mathrm{i}}$ a concentração na interface ar-água. Quanto maior o valor de $K_{H}$, maior é o potencial de volatilização da molécula e, geralmente, este valor diminui com o aumento da solubilidade do componente i.

De acordo com Lyman et al. (1982), a molécula apresenta baixa volatilidade se $K_{\mathrm{H}}<10^{-7}$ atm $\mathrm{m}^{3} \mathrm{~mol}^{-1}$. Entre $10^{-7}$ e $10^{-5}$, volatilidade média. A partir de $10^{-5}$, esse parâmetro começa ser a considerável, sendo que acima de $10^{-3}$, a volatilização torna-se extremamente importante.

A taxa de volatilização também pode variar com o aumento da temperatura. Hulscher et al. (1992) estudaram a relação entre a temperatura e o valor $K_{\mathrm{H}}$ para três clorobenzenos, três bifenóis clorados e seis hidrocarbonetos aromáticos polinucleares. Eles observaram que a cada aumento de $10^{\circ} \mathrm{C}$, o valor de $K_{\mathrm{H}}$ dobrava. No entanto, para a grande maioria dos pesticidas os valores de $K_{\mathrm{H}}$ são inferiores a $10^{-5}$ (Montgomery, 1997).

\subsection{Retenção de pesticidas no solo}

Quando uma molécula de pesticida alcança o solo, ela pode seguir diferentes rumos. Pode ser absorvida pelas plantas e manifestar seu mecanismo de ação, o que é desejável, pode ser transformada, pode ser retida e, caso nenhum desses processos ocorra, a molécula pode ser transportada para diferentes compartimentos do ambiente. 
O processo de retenção retarda, ou em alguns casos até mesmo impede, o movimento das moléculas no perfil. Pode ser reversível ou parcialmente irreversível, podendo afetar os processos de transformação e transporte. Assim sendo, devido à presença prolongada de muitas moléculas no solo, a retenção desempenha um papel preponderante na determinação da eficiência agronômica dos pesticidas, assim como na segurança do ambiente.

O termo sorção é utilizado para descrever o processo de retenção de moléculas orgânicas pelo fato de não se saber se o que está ocorrendo é um fenômeno de adsorção ou se é devido a hidrofobicidade da molécula (partição hidrofóbica). O termo representa a "apreensão" de um soluto pela matriz do solo, sem indicar a extensão do mecanismo envolvido (Bouchard et al., 1989). Quando sorvidas, determinada concentração de moléculas pode novamente retornar a solução do solo, sendo esse processo conhecido como dessorção. Nesse caso, certa concentração do pesticida sorvido encontra-se em equilíbrio com a concentração dele na solução do solo.

Quando uma molécula de pesticida encontra-se sorvida aos colóides, dependendo da energia e do mecanismo da ligação, ela pode se apresentar na forma de resíduo-ligado (não disponível). Isto é, uma forma que não está em equilíbrio com a solução do solo. Entretanto, em alguns casos, parte dessa fração ligada do pesticida pode retornar a solução do solo, sendo esse processo conhecido como remobilização (Lavorenti, 1997). Resíduo-ligado é definido como sendo compostos que persistem no solo, planta ou animal, na forma de molécula original ou de seus metabólitos, após extrações que não alterem significativamente a natureza da molécula nem a estrutura da matriz (Führ et al., 1998).

\subsubsection{Mecanismos de ligação}

O mecanismo de ligação avalia a maneira como o pesticida se liga a outro componente do ambiente no qual ele é aplicado. A energia de ligação entre os pesticidas e os colóides do solo pode variar. Desta forma, os pesticidas podem ser atraídos e sorvidos com diferentes intensidades, o que depende do mecanismo de ligação. Esses mecanismos podem ser subdivididos em químicos, físicos e de interações hidrofóbicas. 


\subsubsection{Adsorção química}

As ligações químicas resultam das interações a pequenas distâncias. São caracterizadas por envolver elevadas energias de adsorção e se dão em tempos relativamente curtos. Dentre estes mecanismos, destancam-se as ligações covalentes e as ligações de hidrogênio.

\subsection{Ligações covalentes}

São as mais fortes ligações químicas possíveis e são formadas pelo compartilhamento de um par de elétrons. Uma vez formada, a ligação covalente raramente se rompe espontaneamente. A energia envolvida neste mecanismo de ligação varia de 50 a $110 \mathrm{kcal} \mathrm{mol}^{1}$, dependendo dos elementos envolvidos. As ligações covalentes podem ser simples, dupla ou tripla (Solomons, 1991).

Dec \& Bollag (1994), estudando o comportamento de várias moléculas organocloradas, concluíram que a liberação de íons $\mathrm{Cl}$ da molécula evidencia a formação de ligação covalente entre os clorofenóis e as substâncias húmicas. De acordo com esses autores, a formação de ligações covalentes dos organoclorados no solo envolve reações oxidativas, as quais podem ser mediadas por enzimas produzidas por microrganismos. Adicionalmente, Katayama et al. (1991) e Katayama et al. (1997) mostraram que o fato do fungicida clorotalonil não ser dissipado em solos autoclavados reforça a idéia de que a atividade microbiana do solo é requerida para a formação de resíduos-ligados de organoclorados e que sua formação está intimamente relacionada à ligação covalente.

A troca de ligantes é um termo muito empregado na literatura. Entretanto, é muitas vezes confundido como um mecanismo de ligação, o qué não é correto. A troca de ligantes é apenas uma maneira, ou um meio de formação da ligação, normalmente covalente. 


\subsection{Ligações de hidrogênio}

O hidrogênio, quando ligado covalentemente a um átomo eletronegativo, normalmente $\mathrm{F}, \mathrm{O}, \mathrm{Cl}$ ou $\mathrm{N}$, pode ser atraído por outro átomo eletronegativo, formando uma ponte, convencionada de ponte de hidrogênio. Aparentemente, a maioria das moléculas de pesticidas possui grupos com potencial para formar ligações de hidrogênio, porém o papel de tais ligações na sorção é incerto. Quando moléculas de água estão presentes há uma tendência dos pesticidas formarem ligações mais fortes com elas do que com a superfície adsorvente. De qualquer modo, a possibilidade de pontes de água ligadas ao hidrogênio entre soluto e adsorvente parece possível, embora até o momento, há apenas evidências indiretas de sua ocorrência. As ligações de hidrogênio possuem polaridade, e sua energia de ligação é da ordem de $5 \mathrm{kcal} \mathrm{mol}^{-1}$ (Solomons, 1991). Um exemplo clássico deste mecanismo é a ligação entre a sílica e o herbicida 2,4-D (Koskinen \& Harper, 1990).

\subsubsection{Adsorção física}

Os processos físicos são caracterizados por envolver baixa energia de sorção (20 kcal $\mathrm{mol}^{-1}$ ou menos). Muitos pesticidas e moléculas dipolares são atraídas para as superfícies desta maneira. Estão incluídas nesta categoria as forças de van der Waals e a ligação iônica.

\subsection{Forças de van der Waals}

Estas forças surgem de flutuações na distribuição de elétrons, produzindo dipolos transientes, os quais causam atração. Elas são fracas, sendo proporcional à sexta potência da distância intermolecular. De qualquer modo, elas podem reforçar atrações manifestadas por forças mais fortes. Podem ser devidas as seguintes situações: (i) forças dipolo-dipolo, resultando de atração mútua entre dipolos permanentes; (ii) forças de dipolo induzido-dipolo induzido (dispersão), resultando de sincronização de movimento eletrônico em cada uma das moléculas produzindo momentos dipolares momentaneamente em cada um; (iii) dipolo-dipolo induzido, resultando de atração de 
um dipolo permanente com o dipolo que ele induz em suas proximidades (Senesi, 1992; Gevao et al., 2000).

\subsection{Ligações iônicas}

As ligações iônicas ou eletrostáticas são formadas à partir de dois íons com cargas opostas e a energia envolvida nestas ligações varia de 4 a $7 \mathrm{kcal} \mathrm{mol}^{-1}$ (Solomons, 1991). As ligações iônicas são importantes na retenção de herbicidas catiônicos como o paraquat e diquat (Goellner, 1995) e de pesticidas ionizáveis, principalmente os que apresentam caráter ácido fraco e valor de $\mathrm{p} K_{\mathrm{a}}$ baixo, assim como os que apresentam caráter de base fraca e $\mathrm{p} K_{\mathrm{a}}$ ' elevado. Rocha et al. (2000) mostraram o efeito do $\mathrm{pH}$ do solo na sorção do herbicida imazaquin, uma molécula com caráter ácido. O imazaquin apresenta dois grupos funcionais ionizáveis: um grupo carboxílico (ácido, $\mathrm{p} K_{\mathrm{a}}=3,8$ ) e um grupo quinolina (básico, $\mathrm{p} K_{\mathrm{a}},=2,0$ ) (Stougaard et al., 1990), sendo que, do ponto de vista agronômico, apenas o grupo carboxílico apresenta importância. Com a elevação do pH dos solos, Rocha et al. (2000) observaram redução na sorção do imazaquin e a explicaram pelo fato da molécula apresentar-se como um ânion nos pHs mais elevados. Resultados semelhantes aos de Rocha et al. (2000) também foram observados previamente por Regitano et al. (1997).

\subsubsection{Interação hidrofóbica}

A interação hidrofóbica, também conhecida como partição hidrofóbica, diz

respeito à afinidade de uma molécula orgânica pela fração orgânica do solo. Essa interação está relacionada aos valores de $K_{\text {ow }}$ da molécula e é de fundamental importância para a sorção de pesticidas hidrofóbicos não iônicos (Koskinen \& Harper, 1990; Prata et al., 2000a).

Alguns estudos de sorção de herbicidas às substâncias húmicas (SH) do solo têm sido realizados com a utilização de técnicas espectroscópicas. Martin-Neto et al. (1999) verificaram que a sorção de atrazina diminuiu com a elevação do pH do meio e explicaram esse resultado através do efeito do pH na conformação estrutural das SH. Em valores de $\mathrm{pH}$ superiores a 5, as $\mathrm{SH}$ apresentavam configuração mais plana, o que 
refletia na formação de um número menor de sítios hidrofóbicos capazes de sorver a atrazina. Por outro lado, em valores de $\mathrm{pH}$ inferiores a 5, a conformação estrutural das SH era mais globular, conferindo-as maior hidrofobicidade e, assim, aumentando a sorção da atrazina. Entretanto, os autores não levaram em consideração as características físico-químicas da atrazina. Isto é, sendo esse herbicida uma molécula básica, com valor de $\mathrm{pK}_{\mathrm{a}}$, em torno de 3 , a proporção de atrazina em sua fase catiônica (em relação a forma neutra) é consideravelmente aumentada com o decréscimo do $\mathrm{pH}$. Levando em consideração que as substâncias húmicas apresentam carga líquida negativa, com o decréscimo do $\mathrm{pH}$ a adsorção iônica também poderia estar contribuindo consideravelmente com a sorção total desse herbicida.

Vários mecanismos de sorção podem atuar ao mesmo tempo sobre as moléculas orgânicas. Por exemplo, o herbicida glifosato pode apresentar vários mecanismos de sorção concomitantes. De forma semelhante ao que ocorre com os fosfatos inorgânicos no solo, um oxigênio do grupo metilfosfônico do glifosato pode formar ligação covalente dativa com os átomos metálicos dos sesquióxidos do solo, constituindo o principal mecanismo de ligação desse herbicida nos solos de regiões tropicais (Jonge et al., 2001). A relação entre as altas taxas de sorção do glifosato e a capacidade dos solos em adsorver fosfatos foi apontada por vários autores (Hance et al., 1976; Glass, 1987; Miles \& Moye, 1988; Gerritse et al., 1996; Jonge et al., 2001). Jonge et al. (2001) mostraram ter havido adsorção competitiva entre o glifosato e o $\mathrm{P}$ inorgânico, mas, entretanto, embora observado um decréscimo nos valores de $K_{\mathrm{f}}$ (coeficiente de Freundlich para sorção) do herbicida, os valores ainda continuavam muito elevados.

Para solos não oxídicos, também tem sido verificado elevados coeficientes de sorção para esse herbicida (Nomura \& Hilton, 1977; Roberts et al., 1998; Prata et al., 2000b), o que mostra que outros mecanismos de sorção também são de fundamental importância para a sorção do glifosato nesses solos.

A molécula do glifosato apresenta uma característica muito particular: possui três valores de $\mathrm{p} K_{\mathrm{a}}$ e um de $\mathrm{p} K_{\mathrm{b}}$, o que lhe confere um comportamento zwiteriônico 
(apresentar cargas positiva e negativa ao mesmo tempo na molécula), característico de aminoácidos.

Miles \& Moye (1988) estudaram a extração do glifosato em solos e minerais de argila e verificaram que a extração foi maior com o aumento do $\mathrm{pH}$ e da força iônica da solução extratora. Eles sugeriram que ligações eletrostáticas e pontes de hidrogênio estavam relacionadas à sorção do glifosato. Todavia, quase que todos os minerais empregados como adsorvente neste estudo foram minerais com carga permanente. Assim, em função do caráter zwiteriônico do glifosato, nos valores de $\mathrm{pH}$ mais baixos as moléculas do herbicida poderiam apresentar uma carga negativa e uma positiva, o que poderia contribuir com a sorção (ligação eletrostática) quando comparado a situações nas quais o $\mathrm{pH}$ foi superior. Quanto maior o $\mathrm{pH}$ do meio, maior a carga líquida negativa do glifosato. Nicholls \& Evans (1991) também observaram o efeito do pH na sorção do glifosato em solos ingleses com cargas permanentes, e também atribuíram os resultados ao efeito do caráter zwiteriônico do glifosato, mostrando adicionalmente a importância das ligações eletrostáticas na sorção deste herbicida.

A contribuição das substâncias húmicas na sorção do glifosato foi verificada por Piccolo et al. (1996). Os autores utilizaram em seu estudo a fração ácido húmico de solos distintos e de alguns resíduos e observaram que a sorção do glifosato relacionou-se com o tamanho molecular das substâncias húmicas, assim como com o grau de alifaticidade das moléculas. Em moléculas húmicas de maior massa molecular e com cadeias carbônicas mais alifáticas, os valores de coeficiente de sorção foram maiores. Os autores ainda sugeriram as ligações de hidrogênio como principal mecanismo de ligação entre o glifosato e as substâncias húmicas, o que corroborou com as especulações feitas previamente por Piccolo et al. (1994). Esta sugestão é fundamentada no fato das moléculas de glifosato possuírem grupos que podem servir como doadores e receptores de prótons e as substâncias húmicas também possuírem grupos funcionais contendo oxigênio. 


\subsubsection{Resíduo -ligado}

Segundo a União Internacional de Química Pura e Aplicada (IUPAC), resíduoligado é o nome dado a interação entre espécies químicas, originadas da transformação ou não de pesticidas, e a matriz do solo, sendo estes resíduos não passíveis de extração por métodos que não alterem significativamente a natureza da molécula (Führ, 1987). No entanto, esse conceito foi ampliado por Führ et al. (1998), sendo que o método de extração também não deve alterar a natureza da matriz, a qual por sua vez, passou a considerar além do solo, as plantas e os animais.

A formação de resíduo-ligado é um importante mecanismo de dissipação de pesticidas no ambiente, pois na grande maioria dos casos, essas moléculas apresentam-se indisponíveis no solo. A formação de resíduo-ligado também influencia diretamente a transformação microbiana dos pesticidas, diminuindo a disponibilidade das moléculas aos microrganismos (Steen et al., 1980; Kawamoto \& Urano, 1989).

Uma proporção significativa das moléculas de pesticidas aplicada na agricultura permanece no solo como resíduo-ligado, sendo que a matéria orgânica é a principal responsável pela formação desses resíduos (Gevao et al., 2000). Além da ligação química, os pesticidas são fortemente retidos pelas frações húmicas por um processo que envolve, provavelmente, sorção às superfícies externas e penetração nos vazios internos das substâncias húmicas e/ou dos microagregados argilo-húmicos com arranjo estrutural tipo peneira (Khan, 1991). Essa penetração, provavelmente, se dê por difusão física numa fase mais lenta da cinética de sorção (Gamble et al., 2000; Regitano et al., 2002).

Os resíduos- ligados podem ser formados tanto com as frações húmicas do solo solúveis em água como também com as altamente polimerizadas, não solúveis (Andreux et al., 1993). Assim, o seu melhor entendimento deve ser ressaltado, pois estes resíduosligados podem ser acumulados na superfície dos solos, já que trabalhos mostram a dificuldade na sua transformação quando comparados com moléculas livres na solução do solo, em alguns casos, até bloqueando a sua transformação (Barriuso et al., 1997).

Algumas pesquisas já foram desenvolvidas com o objetivo de elucidar os mecanismos de formação (Lerch et al., 1997), quantificação e distribuição dos resíduos- 
ligados nas diferentes frações da matéria orgânica do solo (Barriuso \& Koskinen, 1996), biodisponibilidade para plantas (Khan \& Behki, 1990) e sua remobilização no ambiente (Lavorenti, 1997; Liebich et al., 1999; Peixoto et al., 2000; Lavorenti et al., 2001). Entretanto, pouco ainda se sabe sobre este processo.

Com o objetivo de verificar o efeito da aplicação de palha de milho na formação de resíduo ligado e no transporte do herbicida metabenztiazuron num solo orthic Luvisol da Alemanha, sob condição de lisímetro, foi constatado o aumento na formação da fração resíduo-ligado e a redução da lixiviação em $50 \%$, em relação a testemunha (Printz et al, 1995). Adicionalmente, Burauel \& Führ (2000) observaram, também para condições da Alemanha, que cerca de 50 a $80 \%$ do ${ }^{14} \mathrm{C}$-carbono residual da aplicação de pesticidas, em condições de campo (lisímetros), permanece no solo como resíduo-ligado.

Barriuso \& Koskinen (1996) avaliaram a distribuição dos resíduos-ligados de ${ }^{14} \mathrm{C}$-atrazina em diferentes diâmetros de partículas do solo. Eles verificaram a maior concentração dos resíduos-ligados na fração $0,2-2 \mu \mathrm{m}$, a qual continha $50 \%$ do carbono orgânico total do solo. Cerca de 1 dia e após 4 meses da aplicação do herbicida, respectivamente 22 e $55 \%$ da atrazina aplicada encontrava-se na forma de resíduoligado. Ainda com relação à distribuição dos resíduos-ligados de atrazina, Queiroz (1997) verificou que 6,6, 3,3 e 20,3\% da radioatividade aplicada permaneceu como resíduo-ligado nas frações ácido fúlvico, humina e ácido húmico, respectivamente, de um Latossolo Vermelho. Os autores também observaram que a formação de resíduoligado aumentou com o empo, sendo após 15, 60 e 150 dias de incubação, pôde-se extrair 57, 39 e $21 \%$ da radioatividade aplicada, respectivamente.

Gamble et al. (2000) observaram que 30,5\% do total de clorotalonil aplicado num solo arenoso foi caracterizado como resíduo-ligado após apenas 18 dias de incubação. Os autores sugeriram que a formação de resíduo-ligado de clorotalonil segue duas fases: uma fase rápida (aproximadamente 24 horas), a qual, provavelmente seja determinada por processos de superfície, e uma fase lenta, na qual a formação de resíduo-ligado provavelmente se dê por difusão física. 


\subsection{Transformação de pesticidas no solo}

A transformação de um pesticida no solo consiste na alteração da sua estrutura molecular, por meios bióticos ou abióticos. Quando a transformação é total, dando origem a $\mathrm{CO}_{2}, \mathrm{H}_{2} \mathrm{O}$ e íons minerais, é chamada de mineralização. Por outro lado, quando é parcial, dando origem a subprodutos (metabólitos), recebe o nome de metabolização. Os subprodutos resultantes da transformação tendem a diminuir a toxicidade do pesticida, embora possa, ocasionalmente, resultar em componentes mais tóxicos do que a própria molécula original (Cox, 1997). Muitas vezes o termo transformação é tratado como degradação.

Os processos abióticos de transformação dos pesticidas apresentam pouca importancia, sendo fundamentados, principalmente, na transformação química e na fotodegradação. Já os processos bióticos, também conhecidos como biodegradação, são processos realizados extra-ou intra-celularmente pela ação de enzimas secretadas por microrganismos, e apresentam importância fundamental no processo de transformação de pesticidas no solo.

\subsubsection{Transformações abióticas}

A transformação abiótica de um pesticida no solo ocorre quando a molécula é transformada pela ação de componentes físicos ou químicos do ambiente. Reações abióticas compreendem todas aquelas reações que não são enzimáticas, mas são iniciadas por espécies químicas ou funções moleculares reativas no solo, ou por catálise de constituintes não vivos do solo tais como superfícies orgânicas ou minerais. Os grupos $\mathrm{COOH}^{-}, \mathrm{OH}^{-}$, ou $\mathrm{C}=\mathrm{O}^{-}$, por exemplo, são radicais nucleofílicos de moléculas orgânicas do solo que reagem com os pesticidas. Os radicais livres presentes no solo também podem reagir quimicamente com os pesticidas.

\subsubsection{Transformação química}

O principal mecanismo de reação química importante na transformação de pesticidas no solo é a hidrólise. Ela é influenciada, no solo e na água, pelo valor do pH, 
temperatura e pela sorção do pesticida. A hidrólise é um processo de transformação química, no qual uma molécula orgânica, $R X$, reage com a água, formando uma nova ligação carbono-oxigênio e rompendo uma ligação carbono- $X$ na molécula original (Wolfe et al., 1990). A reação líquida é, geralmente, um deslocamento direto de $X$ por $\mathrm{OH}$ :

$$
\mathrm{RX} \stackrel{\mathrm{H}_{2} \mathrm{O}}{\longrightarrow} \mathrm{ROH}+\mathrm{X}^{-}+\mathrm{H}^{+}
$$

A hidrólise, assim como outros mecanismos de quebra de moléculas, tem sido bastante abordada na literatura (Greenhalgh et al., 1980; Macalady \& Wolfe, 1983; Morrica et al., 2001; Sabadie, 2002). Entretanto, o estudo da contribuição de cada processo abiótico na transformação de um pesticida no solo torna-se praticamente impossível, devido à complexidade do sistema.

Grupos funcionais como ésteres de ácido carboxílico, ésteres de organofosforados, amidas, anilinas, carbamatos, azinas etc., comumente encontrados em muitos pesticidas, são passíveis de sofrer hidrólise (Sabadie, 2002). Os ésteres de ácido carboxílico, por exemplo, estão presentes nos herbicidas 2,4-D; 2,4,5-T e em alguns inseticidas do grupo dos piretróides. Sua hidrólise consiste na formação de ácido carboxílico e álcool (Zepp et al., 1975). Os ésteres de organofosforados podem sofrer hidrólise alcalina e neutra (Smith et al., 1978). A hidrólise alcalina resulta na quebra da ligação P-O, produzindo ácidos fosfórico ou tiofosfórico e álcool. A hidrólise neutra ocorre, normalmente, via quebra da ligação C-O e os produtos finais são os mesmos da hidrólise alcalina (Greenhalgh et al., 1980; Macalady \& Wolfe, 1983; Morrica et al., 2001).

Os mecanismos de sorção têm sido caracterizados como importante catalisador do processo de hidrólise. Isso foi evidenciado desde os experimentos de Armstrong et al. (1967), que observaram a formação de hidroxiatrazina (metabólito da atrazina) nas soluções percoladas de colunas de solo esterilizado, com pH 3,9. Nessas mesmas condições, foi observada uma redução de dez vezes na cinética de hidrólise quando os tratamentos não continham solo. 
A presença de íons metálicos no solo, como $\mathrm{Fe}^{2+}, \mathrm{Zn}^{2+}, \mathrm{Cu}^{2+}, \mathrm{Mn}^{2+}, \mathrm{Al}^{3+}$ etc., também pode contribuir para a catálise da hidrólise de alguns pesticidas. Blanchet \& StGeorge (1982) mostraram que a quelatação de $\mathrm{Cu}^{2+}$ e $\mathrm{Mn}^{2+}$ pelo $\mathrm{S}$ e $\mathrm{N}$ do clorpirifós, pode resultar em hidroxilação e desmetilação no radical éster dessa molécula. Esse efeito

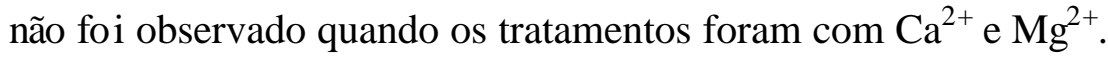

\subsubsection{Fotodegradação}

É possível observar fotodegradação (fotólise) da estrutura molecular de um pesticida na superfície do solo ou folha de uma planta quando ocorre a ação da luz. Geralmente, a luz apresenta um papel de catalisador de reações químicas como a hidrólise, oxidação, redução etc., e os produtos da transformação resultantes destas reações são, algumas vezes, os mesmos que são encontrados em decorrência dos

processos enzimáticos. É muito difícil diferenciar a origem dos processos de transformação no solo (se abiótica ou enzimática).

Após a aplicação, os pesticidas permanecem na superfície das plantas ou na camada superior do solo, onde são expostos à radiação solar. O efeito da energia radiante, com comprimento de onda entre 290 e $450 \mathrm{~nm}$, causa sensibilização fotoquímica e promoção da quebra de muitos pesticidas, principalmente na superfície das folhas (Pierzynski et al., 1994). Para absorver radiação na região do ultravioleta (UV), com energia suficiente para romper ligações químicas, o pesticida precisa possuir insaturação eletrônica, normalmente como os elétrons $\pi$ deslocados (cromóforos) (Hugue et al., 2002). Também pode ocorrer uma reação fotoquímica indireta, na qual uma espécie reativa é produzida fotoquimicamente através da absorção de radiação UV por uma molécula (Fay et al., 1997; Hugue et al., 2002).

Uma molécula de pesticida não necessita absorver energia radiante diretamente para que ocorra o processo fotoquímico. Se uma molécula (aceptora) está em contato com outra espécie (doadora) excitada pela luz, esta pode transferir a energia de excitação para a aceptora, que pode, então, sofrer a reação fotoquímica como se tivesse adquirido a energia radiante diretamente. Esse processo recebe o nome de fotossensibilização. A conversão de aldrin a dieldrin, em laboratório, induzida pela luz ultravioleta de baixa 
energia, em solução de benzeno, e na presença de benzofenona como fotossensibilizador, é um exemplo do processo de fotossensibilização. Na ausência de benzofenona, essa transformação é cerca de 80 vezes inferior à observada na sua presença (Rosen, 1972). Embora a identidade dos fotossensibilizadores seja muitas vezes desconhecida, as substâncias húmicas, os minerais de argila e os metais de transição, provavelmente, estejam envolvidos nesse processo (Wolfe et al., 1990).

A extensão da fotodegradação depende do tempo de exposição, da intensidade, do comprimento de onda da luz, do estado físico do pesticida, da natureza do suporte sólido ou solvente, $\mathrm{pH}$ da solução e presença de água e fotossensibilizadores (Vulliet et al., 2002). Um exemplo clássico e prático de fotodegradação refere-se ao herbicida trifluralina. Em função de suas propriedades físico-químicas, esse herbicida deve ser incorporado após sua aplicação no solo na maioria de suas formulações comerciais, o que, praticamente, o restringe a um herbicida de pré-plantio incorporado (PPI).

Dentre as principais reações fotoquímicas, destacam-se: a hidrólise, a desalogenação, a oxidação, a isomerização e a polimerização (Qare-Abu \& Duncan, 2002). A substituição de um halogênio de um benzeno por uma hidroxila, na presença de um agente nucleofílico em solução aquosa, é um exemplo de uma reação fotonucleofílica de hidrólise (Matsumura, 1982).

A hidrólise é a reação fotoquímica predominante para os carbamatos e organofosforados em soluções aquosas. A desalogenação é a reação fotoquímica mais comum. Devido à elevada energia envolvida, a irradiação ultravioleta pode desalogenar diretamente até mesmo os halogênios mais estáveis ligados a anéis aromáticos. Alguns exemplos dessas reações fotoquímicas ocorrem nas bifenilas policloradas (PCBs), uréias substituídas cloradas como o monuron, diuron, cinosulfuron, triasulfuron e pentaclorofenóis (Wolfe et al., 1990; Vulliet et al., 2002).

Talvez a reação fotoxidativa mais importante para pesticidas seja a conversão $\mathrm{P}=\mathrm{S}$ para $\mathrm{P}=\mathrm{O}$, no caso dos organofosforados. Um processo de oxidação de significância toxicológica é a conversão de tiofosfatos para fosfatos, que geralmente resulta em compostos com dose letal média $\left(\mathrm{DL}_{50}\right)$ inferiores. O paration é um exemplo disso, pois 
quando fotoxidado passa a paraoxon, que é um metabólito mais tóxico que a molécula original (Wolfe et al., 1990).

\subsubsection{Transformação biótica - Biodegradação}

A maioria das moléculas de pesticida é transformada pela ação do metabolismo dos microrganismos no solo. Assim, o termo biodegradação, tipicamente, refere-se a transformação microbiológica de um composto orgânico para outra forma, sem se referir à extensão (Monteiro, 1997).

A transformação microbiana pode acontecer por reações metabólicas diretas, consideradas primárias, ou por efeitos indiretos dos microrganismos com as propriedades físicas e químicas do solo, resultando em transformações secundárias (Bollag \& Liu, 1990). Dessa forma, são cinco os processos envolvidos nas transformações microbianas de pesticidas no solo:

- Catabolismo: o pesticida serve como fonte de energia e/ou nutrientes para o crescimento e desenvolvimento dos microrganismos degradadores. Por exemplo, a transformação do herbicida glifosato pode ser induzida na ausência de $\mathrm{P}$ no meio, funcionando, assim, como fonte de fósforo a determinadas espécies de microrganismos (Eijsackers, 1985).

- Cometabolismo: o pesticida é transformado por reações metabólicas, mas não serve como fonte primária de energia e/ou nutrientes para o microrganismo. Normalmente, a molécula não é transformada completamente. Através da adição de materiais orgânicos ao solo, pode-se evidenciar a transformação cometabólica de pesticidas no solo. O fato dessa adição aumentar a atividade e/ou biomassa microbiana sugere que a transformação de muitos pesticidas, como por exemplo os herbicidas diuron e ametrina, ocorre também por processos cometabólicos (Costa, 1992; Prata et al., 2000a; Prata et al., 2001).

- Polimerização ou conjugação: a molécula original do pesticida, ou de um de seus metabólitos, se combina com compostos naturais do solo, como 
aminoácidos ou carboidratos, ou com outra molécula de pesticida. A formação do conjugado normalmente torna a molécula mais polar e, assim, mais hidrolisável. A formação do metabólito dicloroanilina, característico de muitos herbicidas derivados da uréia, tais como o diuron, isoproturon, monuron etc., pode ser considerado resultante da polimerização de metabólitos mais simples, isto é, duas moléculas de diuron devem ser transformadas para que seja formada uma molécula de dicloroanilina (Roberts et al., 1998).

- Acúmulo: ocorre quando a molécula de um pesticida é incorporada ao microrganismo, sem que seja transformada. O acúmulo de moléculas por microrganismos pode ocorrer por um processo ativo ou passivo e traz uma grande preocupação, uma vez que essa interferência microbiana significa apenas a remoção temporária da molécula. Moléculas de organoclorados como DDT, dieldrin, aldrin e heptacloro, foram detectadas em células de fungos, acumuladas no vacúolo (Musumesci, 1992). Outro exemplo de acúmulo está relacionado ao difluobenzuron em Pseudomonas sp. Cerca de até $10.000 \mu \mathrm{g} \mathrm{g}^{-1}$ de diflubenzuron foram encontrados dentro da célula (Monteiro, 1997).

- Efeitos secundários da atividade microbiana: ocorre quando o pesticida é transformado em decorrência de alterações no $\mathrm{pH}$, potencial redox etc., promovidas pela atividade microbiana. A elevação do $\mathrm{pH}$, por exemplo, pode contribuir com a hidroxilação de muitas moléculas, tornando-as mais polares e, assim, mais passíveis de serem degradadas (Prata et al., 2000a).

Em síntese, a biodegradação ocorre em função da produção de enzimas por microrganismos degradadores de pesticidas, as quais em contato com essas moléculas, dentro ou fora das células microbianas, participam de uma série de reações, tais como: oxidação, redução, hidrólise, desalquilação, descarboxilação, hidroxilação, metilação, desalcoxilação etc. (Lavorenti, 1996). 
O termo dissipação é bastante utilizado no estudo do comportamento de pesticidas no ambiente. Esse termo refere-se à fração do pesticida que é mineralizada ou permanece no solo em formas que não a original, ou seja, a dissipação brange a mineralização, a metabolização, a formação de resíduo-ligado, a absorção e o transporte do pesticida. $O$ índice de meia-vida $\left(t_{1 / 2}\right)$ expressa o tempo em que $50 \%$ da concentração total aplicada encontra-se dissipada no solo.

Existem casos em que a molécula é rapidamente dissipada, sendo transformada em metabólitos ou apresentando rápida cinética de formação de resíduo-ligado, mas tais metabólitos podem ser tão quanto ou mais tóxicos que a própria molécula original e/ou, em outros casos, pode haver a remobilização de seus resíduos-ligados, tornando-se novamente ativos. O fungicida clorotalonil, o herbicida atrazina e o inseticida paration são exemplos do primeiro caso (Cox, 1997; Peixoto, 1998) e a própria atrazina, a anilazina, o metabenztiazuron etc., são exemplos de moléculas que podem apresentar remobilização de sua fase resíduo-ligado (Printz et al., 1995; Lavorenti, 1997; Liebich et al., 1999; Peixoto et al., 2000; Lavorenti et al., 2001).

A meia-vida, pelo fato de envolver a dissipação da molécula original, pode não representar bem o destino de um pesticida em determinados casos específicos, como por exemplo, o do clorotalonil, o da atrazina e o do paration em determinados ambientes. Nesses casos, também seria interessante a caracterização da meia-vida dos metabólitos tóxicos. No entanto, a meia-vida propriamente dita representa bem para a maioria das situações, mostrando valores muito inferiores em relação à meia-vida de mineralização, a qual tem sido determinada em alguns trabalhos antigos, como o de Nomura \& Hilton (1977). Um entre os vários exemplos de molécula com elevada meia-vida de mineralização ( $t_{1 / 2}$ min.) e baixa meia-vida de dissipação $\left(t_{1 / 2}\right)$ é o herbicida glifosato. Essa molécula apresenta $t_{1 / 2} \mathrm{~min}$. de até 22,7 anos para solos vulcânicos, com elevado grau de sorção (Nomura \& Hilton, 1977) e $t_{1 / 2}$ em torno de 19 dias (Cheah et al., 1998) para a maioria dos solos. Apesar do glifosato ser uma molécula bastante rica em energia, e constituída de $\mathrm{C}, \mathrm{H}, \mathrm{O}, \mathrm{P}$ e $\mathrm{N}$, o que a torna altamente biodegradável em meio líquido sem adsorventes. No solo, sua mineralização é comprometida pela sua alta taxa de ligação com a fração coloidal (Piccolo et al., 1996). 
Um outro aspecto muito interessante relacionado à transformação microbiana de pesticidas no solo, diz respeito à adição de materiais orgânicos ao meio. Materiais orgânicos reduzidos e prontamente disponíveis, como por exemplo a vinhaça, tendem a contribuir com o aumento da atividade microbiana e, consequentemente, com o aumento da degradação de pesticidas, principalmente por cometabolismo (Prata \& Lavorenti, 2001). Prata et al. (2000a; 2001) demonstraram o efeito da adição de vinhaça, em doses equivalentes a 100 e $200 \mathrm{~m}^{3} \mathrm{ha}^{-1}$, na degradação e sorção de diuron e ametrina em um Nitossolo Vermelho Eutroférrico argiloso e um Latossolo Vermelho textura média. Os autores verificaram que a persistência dessas moléculas foi reduzida com a adição de vinhaça ao solo, o que estava relacionado com o aumento da atividade microbiana.

A transformação de ${ }^{14} \mathrm{C}$-ametrina num Neossolo Quartzarênico da região de Piracicaba-SP, foi estudada por Costa (1992). O estudo foi realizado sob condições de solo esterilizado e não esterilizado, com adição de folhas secas de cana-de-açúcar cultivada em solo tratado e não tratado com a ame trina, nos três anos anteriores a coleta. Nos solos esterilizados, tratados e não tratados, praticamente não foi observado o desprendimento de ${ }^{14} \mathrm{CO}_{2}$. Com a adição do material vegetal oriundo de campos tratados e não tratados, a proporção de ${ }^{14} \mathrm{CO}_{2}$ desprendido foi respectivamente de $13 \mathrm{e}$ 12 vezes superior em relação ao solo sem a adição de substrato, mostrando que a transformação da ametrina ocorre, principalmente, por cometabolismo. A adição de rizosfera da mesma cultura, com e sem os tratamentos anteriores do herbicida, também acelerou a transformação, com desprendimento de ${ }^{14} \mathrm{CO}_{2}$ de 3,5 e 1,7 vezes maiores nos solos tratados e não tratados, respectivamente. Isto mostrou a ocorrência de seleção de microrganismos durante os três anos consecutivos de aplicação do herbicida no campo.

A degradação de um pesticida no solo muitas vezes está relacionada a microrganismos ou grupos de microrganismos específicos. Por exemplo, Kontchou \& Gschwind (1995) mostraram que a degradação da atrazina em vários solos foi aumentada em 50 \% após incubação com a linhagem YAYA6, de Pseudomonas, crescida em meio líquido contendo somente atrazina como fonte de carbono. Nos solos com alto teor de matéria orgânica, a biodegradação da atrazina foi limitada pelos mecanismos de sorção. 
A adaptação dos microrganismos do solo a determinados pesticidas é um processo comum e tem sido verificada em muitos estudos. Neste caso, em áreas com aplicações prévias de determinadas moléculas, a persistência das mesmas pode ser consideravelmente reduzida (Papini \& Andréa, 2001). Esta alteração na velocidade de transformação leva o nome de biodegradação acelerada. $\mathrm{O}$ inseticida carbofuran pode ser considerado um exemplo disso, pois já houve relatos da redução de sua eficiência no controle de insetos em áreas americanas e canadenses com aplicações prévias dessa molécula (Racke, 1990). Pelo fato da biodegradação acelerada decorrer provavelmente de processos catabólicos, a atividade e/ou biomassa microbiana de microrganismos degradadores pode ser aumentada em solos com sucessivas aplicações de um determinado pesticida (Costa, 1992).

A transformação de pesticidas é constituída, na maioria das vezes, por processos distintos e complexos, os quais são influenciados pelos mais diferenciados fatores. Isso faz com que o processo de transformação seja específico para cada molécula. Por exemplo, o herbicida 2,4,5-T, apesar de ser do mesmo grupo do 2,4-D, apresenta uma persistência muito maior, o que está relacionado a sua toxicidade e a de seus metabólitos aos microrganismos (Somasundaram \& Coats, 1990).

O tipo de formulação, os solventes utilizados e os surfactantes também podem influenciar na transformação dos pesticidas. Pesticidas em formulações granuladas, por exemplo, tendem a ser mais persistentes que concentrados emulsionáveis e outros. Os solventes, emulsificantes, estabilizantes, espalhantes e algumas impurezas da síntese do ingrediente ativo são capazes, potencialmente, de afetar a microbiota do solo (Monteiro, 1997).

\subsection{Transporte de pesticidas no solo}

O transporte de pesticidas no ambiente pode ocorrer através da sua movimentação vertical no solo, processo conhecido como lixiviação, da volatilização da molécula, ou através do escorrimento superficial ou "runoff" (Enfield \& Yates, 1990). 


\subsubsection{Movimentação no perfil do solo - Lixiviação}

A lixiviação é a principal forma de transporte no solo das moléculas não voláteis e solúveis em água (Enfield \& Yates, 1990; Ayeni et al., 1998). Essas moléculas caminham no perfil, acompanhando o fluxo de água, o qual é governado pela diferença de potencial da água entre dois pontos.

Quando uma molécula orgânica é lixiviada, pode atingir zonas subsuperficiais no perfil e, em alguns casos, pode até mesmo alcançar o lençol freático, acarretando em impactos ambientais.

A disponibilidade e, consequentemente, o transporte de pesticidas no solo são governados pelos processos de sorção, transformação e absorção radicular das moléculas, aliados às condições ambientais (pluviosidade, temperatura etc.). Assim, as propriedades físico-químicas das moléculas, como por exemplo, a hidrofobicidade $\left(K_{\mathrm{ow}}\right)$, $\mathrm{p} K_{\mathrm{a}}$, solubilidade em água etc., e os atributos físicos, químicos e biológicos do solo, destacando-se a estrutura, classe textural, mineralogia, conteúdo de matéria orgânica, pH, CTC, atividade e biomassa microbiana etc., refletem diretamente na movimentação das moléculas no perfil do solo (Bouchard et al., 1989).

Moléculas altamente sorvidas aos colóides do solo, como os herbicidas glifosato, paraquat e diquat, tendem a ser pouco lixiviadas (Cheah et al., 1997), dependendo principalmente da estrutura e textura do solo e do índice pluviométrico. Moléculas que são rapidamente mineralizadas, como o 2,4-D, também apresentam baixo potencial de lixiviação (Enfiled \& Yates, 1990).

De forma geral, os principais fatores determinantes da lixiviação de pesticidas no solo são a solubilidade em água da molécula, a textura e a estrutura do solo e o índice pluviométrico da região em questão. Assim, moléculas com elevada solubilidade em água $\left(S_{\mathrm{w}}>300 \mathrm{mg} \mathrm{L}^{-1}\right)$, como por exemplo, o herbicida picloram, em solo arenoso e em região com elevado índice pluviométrico, apresenta um considerável potencial de lixiviação. As consequências práticas disto foram observadas por Merkle \& Bovey (1974), ao constatarem concentração de picloram em água de irrigação. Pang et al. (2000), também determinaram picloram em cursos de água na Nova Zelândia. Ainda 
com relação ao herbicida picloram, essa molécula apresenta valores bastante elevados de $t_{1 / 2}$, atingindo valores de até 3 anos em determinados casos (Montgomery, 1997), o que ressalta ainda mais o seu potencial de lixiviação (U.S.EPA, 1986).

A lixiviação potencial dos herbicidas 2,4,5-T, dicamba, MCPA, diclofop, quinclorac, bromoxinil, fenoxaprop, trialate e trifluralina foi estudada por Hill et al. (2000) em colunas preenchidas com diferentes tipos de solo. Foi verificado, de maneira geral, que os herbicidas dicamba, 2,4-D, MCPA e quinclorac lixiviaram mais rapidamente, seguidos do bromoxinil, diclofop, fenoxiprop e trialate, sendo que a trifluralina praticamente não foi lixiviada. Esses resultados puderam ser relacionados às propriedades físico-químicas desses herbicidas, tendo sido lixiviado mais aqueles que apresentavam maior solubilidade em água e menores valores de $K_{\mathrm{oc}}$.

Muitos são os exemplos de moléculas de pesticidas detectadas em cursos de água. Em amostras de água subterrânea de 4 estados nos Estados Unidos, foi constatado a presença do fungicida clorotalonil e de seu metabólito hidroxiclorotalonil, que é 30 vezes mais tóxico para mamíferos que a própria molécula original (Cox, 1997). A atrazina e seus metabólitos desetilatrazina (DEA) e desisopropilatrazina (DIA) foram encontradas em amostras de água do rio Mississippi (Pereira \& Rostad, 1990).

De acordo com Langenbach et al. (2000), a atrazina é o herbicida mais encontrado em cursos de água no mundo. Vários estudos de monitoramento ambiental, em áreas norte-americanas, têm mostrado a presença da atrazina e de seus metabólitos; DEA e DIA, em cursos de água tanto superficiais como subsuperficiais (Pereira \& Rostad, 1991; Thurman et al., 1991; Thurman et al., 1994; Cai et al., 1994; Lerch et al., 1998). No entanto, resultados desta natureza são praticamente inexistentes para as condições brasileiras.

A extensão da mobilidade da atrazina está relacionada ao conteúdo de matéria orgânica do solo (Moreau \& Mouvet, 1997; Mersie \& Seybold, 1997), o qual, por sua vez, também está envolvido na metabolização deste herbicida. A metabolização da atrazina em hidroxiatrazina (HA), seu principal metabólito (Lerch et al., 1999), ocorre principalmente via hidrólise química, e é catalisada pelos processos de sorção (devido à 
matéria orgânica) e por baixos valores de pH (Lerch et al., 1998). Martin-Neto et al. (2001) mostraram que a transferência de prótons entre a atrazina e as substâncias húmicas do solo pode contribuir na metabolização da atrazina em HA e aumentar sua sorção, mostrando que a matéria orgânica pode atuar no retardamento da lixiviação da atrazina de diferentes maneiras.

Em solos oxídicos, característicos de regiões sob clima tropical, o fato do horizonte B poder, em alguns casos, apresentar balanço de cargas positivo, como por exemplo, o caso dos solos ácricos da região de Ribeirão Preto e Guaíra, SP (Rocha et al., 2000; Regitano et al., 2002), pode retardar o tranporte de moléculas com comportamento de ácido fraco. Esses herbicidas apresentam carga negativa nos valores de $\mathrm{pH}$ comumente encontrados em solos sob clima tropical, o que contribui para sua lixiviação nas camadas superficiais, mas, no entanto, parte pode ficar sorvida no horizonte B desses solos em função dos elevados valores de PCZ (ponto de carga zero). Resultados nesse sentido foram obtidos por Rocha et al. (2001) em estudos de lixiviação de imazaquin em colunas preenchidas com amostras de solos ácricos coletadas em superfície e subsuperfície. Para esses mesmos solos, Regitano et al. (2002b) verificaram que a lixiviação do imazaquin relacionoutse com o período de secagem do solo após a aplicação do herbicida. Os autores mostraram que quanto maior o período de secagem, menor a lixiviação da molécula para o solo argiloso, o que foi atribuído a alterações no processo de sorção.

Enfield (1985) mostrou que, ao contrário do que se pensava, o movimento de pesticidas no solo pode ocorrer também para moléculas hidrofóbicas. Essas moléculas podem associar-se a macromoléculas orgânicas solúveis em água, e serem transportadas verticalmente no perfil. A fração de ácidos fúlvicos da matéria orgânica é um exemplo de macromolécula solúvel em água. Nesse caso, a lixiviação não seria do pesticida propriamente dito, mas sim de sua fração resíduo-ligado (Barriuso et al., 1997). Recentes estudos têm mostrado uma maior preocupação com a lixiviação de moléculas hidrofóbicas associadas ao carbono orgânico dissolvido (COD) do solo (Lafrance et al., 1994; Vereecken et al., 2001). Enfield \& Bengtsson (1988) discutiram o impacto de macromoléculas na mobilidade de pesticidas no solo. Os autores propuseram que a 
lixiviação dos pesticidas hidrofóbicos associados às macromoléculas pode ocorrer pelo fato do conjunto ser excluído dos poros menores do solo e assim poder apresentar mobilidade até maior que a própria água.

A lixiviação de glifosato em colunas preenchidas com amostras indeformadas de um solo dinamarquês arenoso foi abordada por Jonge et al. (2000). No entanto, o valor de $K_{\mathrm{f}}$ (coeficiente de Freundlich para sorção) neste experimento foi da ordem de $57\left[\left(\mathrm{mg} \mathrm{g}^{-1}\right)\left(\mathrm{mL} \mathrm{mg}^{-1}\right)^{\mathrm{N}}\right]$ e a radioatividade, considerada como concentração de glifosato, na solução percolada das colunas variou proporcionalmente com a turbidez da solução, indicando que a molécula foi lixiviada, provavelmente, na forma de resíduoligado.

Por outro lado, a formação de resíduos-ligados, via de regra, denota maior importância no sentido de retardar a lixiviação, pois a maior parte desta fração apresenta-se numa forma pouco solúvel. Por exemplo, Printz et al. (1995) verificaram que a formação de resíduo-ligado de metabenztiazuron contribuiu com uma redução de $50 \%$ na lixiviação desta molécula.

A lixiviação potencial de pesticidas no solo pode ser determinada por alguns métodos diferentes como, por exemplo, através da percolação em colunas preenchidas com amostras deformadas ou indeformadas de solo, assim como os estudos em lisímetros. Entretanto, estudos sob condições de lisímetros são extramamente onerosos e, portanto, muito limitados no Brasil. Assim, os estudos de lixiviação potencial no Brasil ficam restritos às colunas. No entanto, existem muitos modelos matemáticos que podem relacionar algumas propriedades do solo, do pesticida e do fluxo de água, com o potencial de lixiviação da molécula (Sun, 1996; Vereecken et al., 2001).

A determinação do índice fator de retardo $(R)$ tem sido amplamente utilizada nas pesquisas de lixiviação de pesticidas em colunas de solo, envolvendo deslocamento miscivel e "breakthrough curves" (BTC) (Parker \& van Genuchten, 1984; Kookana et al., 1993; Gonzalez \& Ukrainczyk, 1999; Vereecken et al., 2001). Esse índice $(R)$ representa o efeito da matriz (sorção) na retardação da lixiviação do soluto. Para sua determinação, no entanto, faz-se impressindível o uso de traçadores nos experimentos de 
lixiviação, como por exemplo, os íons $\mathrm{Br}^{-}$ou $\mathrm{CI}$, sendo que devem ser determinadas as BTCs dos traçadores e do pesticida.

O cálculo do fator de retardo é muitas vezes efetuado de forma grosseira relacionando-se o valor de $K_{\mathrm{d}}$ obtido por experimentos "batch", densidade do solo $(\rho)$ e o conteúdo de água no solo $(\theta)$ :

$$
R=1+\left(\frac{\rho \cdot K d}{\theta}\right)
$$

Entretanto, o valor "real" de $R$ deve ser determinado através de equações matemáticas muito mais complexas, baseadas na equação de convecção-dispersão (Vereecken et al., 2001) e derivadas das "breakthrough curves" de traçadores e do pesticida em questão (Gonzalez \& Ukrainczyk, 1999). Para tal, o uso de modelagem matemática tem sido um grande artifício. O modelo de van Genuchten \& Wagenet (1989), "two site/two region", tem sido um dos mais empregados para o estudo da lixiviação de pesticidas em colunas de solo. Esse modelo considera o não-equilíbrio químico e o não-equilíbrio físico de sorção, para fornecer parâmetros de transporte da molécula como o fator de retardo, assim como parâmetros de sorção, como as concentrações sorvidas em sítios em equilíbrio e em não-equilíbrio com a solução do solo.

Um parâmetro muito utilizado na determinação do potencial de lixiviação de pesticidas, e que apresenta sérias limitações, é o chamado índice GUS (Groundwater Ubiquity Score), estabelecido por Gustafson (1989):

$$
G U S=\log \left(t_{1 / 2}\right) \times\left[4,0-\log \left(K_{\mathrm{oc}}\right)\right]
$$

A equação (29) leva em consideração a persistência da molécula no solo e a força da matriz envolvida no impedimento da lixiviação do pesticida. Quanto maior a meia-vida e menor a sorção da molécula, maior será o valor de GUS, ou seja, maior seu potencial de lixiviação no perfil. De acordo com a classificação de Gustafson (1989), moléculas com valores de GUS inferiores a 1,8 apresentam baixo potencial de lixiviação. Moléculas com valores superiores a 2,8 apresentam potencial de lixiviação elevado e moléculas com valores entre 1,8 e 2,8 pertencem a um grupo de transição e 
merecem ser analisadas caso a caso. Entretanto, críticas severas podem ser feitas a esse modelo, como por exemplo, o fato de se usar $K_{\mathrm{oc}}$ e não $K_{\mathrm{d}}$, e a omissão de propriedades físico-químicos da molécula determinantes no seu potencial de lixiviação, como sua solubilidade em água $\left(S_{\mathrm{w}}\right)$ e seu coeficiente de partição n-octanol/água $\left(K_{\mathrm{ow}}\right)$. O modelo também não considera parâmetros ambientais e do solo, como taxa de recarga, porosidade do solo, condutividade hidráulica, capacidade de campo etc. $\mathrm{O}$ autor justifica algumas dessas críticas pelo fato do carbono orgânico ser o principal fator determinante na sorção da maioria das moléculas para solos dos EUA, pela solubilidade em água dos pesticidas poder ser desconsiderada no solo em função das baixíssimas concentrações dos pesticidas na solução do solo, muito abaixo de sua solubilidade, e também pelo fato do $K_{\mathrm{ow}}$ não apresentar boa correlação com a lixiviação potencial.

\subsubsection{Escorrimento superficial - "Runoff"}

A movimentação do pesticida ao longo da superfície do solo, juntamente com o escorrimento da água da chuva ou até mesmo pelo vento, até a superfície das águas dos rios, lagos e terrenos de menor declividade, é conhecido como escorrimento superficial ou "runoff".

A concentração do pesticida e a distância que ele é transportado são influenciados por fatores tais como: taxa de aplicação, propriedades físico-químicas do pesticida e do solo, o tempo antes que ocorra a erosão seguindo a aplicação, quantidade de precipitação versus taxa de infiltração, a topografia do terreno e o tipo de cobertura vegetal (Leonard, 1990). A deposição de pesticidas é o resultado final do transporte de massa superficial, a qual é influenciada pela velocidade da força carregadora (água ou vento) e o tamanho da partícula no qual o pesticida pode estar sorvido.

O transporte de um pesticida por escorrimento superficial não é tão previsível como o é por lixiviação, no qual pode-se ter como base as propriedades físico-químicas do pesticida. O escorrimento superficial é muito dependente dos padrões de uso, condições climáticas e geografia. Ao se efetivar um processo de "runoff", pouco importa se o pesticida tem um valor de $K_{\mathrm{d}}$ ou $K_{\mathrm{oc}}$ baixo ou elevado, pois o pesticida poderá ser 
transportado tanto sorvido às partículas do solo como livre na solução do solo (Schuz, 2001).

Alguns experimentos foram realizados mostrando a importância do "runoff" no transporte de pesticidas no ambiente, destacando-se os ensaios de Leonard (1988) e Konda \& Pasztor (2001), para o herbicida atrazina e os de Connolly et al. (2001), para o endosulfan.

O plantio direto é a prática cultural de maior importância na redução do escorrimento superficial. Os estudos de Triplett et al. (1978) mostraram a redução do transporte de atrazina e simazina devido ao "runoff", em áreas sob este sistema de cultivo, o que mais tarde foi comprovado nos trabalhos de Sadeghi \& Isensee (1997) para o alaclor.

\subsubsection{Volatilização}

Este processo é responsável pela distribuição do pesticida das superfícies do solo, planta ou água para a atmosfera. Cada pesticida tem uma tendência a mudar da fase sólida para líquida e desta para vapor devido ao movimento ou energia da molécula que o compõe. A tendência de uma molécula no estado líquido passar para o estado gasoso (ou volatilizar) é indicado por sua pressão de vapor (Montgomery, 1997).

Uma vez que um pesticida adentra no ambiente, sua entrada e transporte através da atmosfera vão depender de vários fatores tais como a pressão de vapor, a entalpia de vaporização da molécula, o coeficiente de partição entre a atmosfera e qualquer outra fase e o fluxo de massa de ar, o qual transportará qualquer pesticida disperso na fase atmosférica (Glotfelty \& Schomburg, 1989; Taylor \& Spencer, 1990).

Os pesticidas muito voláteis requerem incorporação no solo, independente das condições de clima ou de solo. Os herbicidas do grupo dos tiocarbamatos, como o molinate, EPTC e o vernolate, necesssitam ser incorporados, ao menos até 7,5 cm de profundidade, para prolongar sua permanência no solo (Deuber, 1992).

O herbicida 2,4-D, dependendo da sua formulação, pode apresentar diferenças na sua volatização em função dos diferentes valores de sua pressão de vapor $(P)$. Sua 
formulação sal amina apresenta $P=5,5 \times 10^{-7} \mathrm{~mm} \mathrm{Hg}$ a $30^{\circ} \mathrm{C}$, enquanto que as formulações éster butílico e isooctílico apresentam valores de $2,3 \times 10^{-3}$ e 3,0 x $10^{-4} \mathrm{~mm}$ $\mathrm{Hg}$, respectivamente (Deuber, 1992).

Embora a pressão de vapor de um pesticida determine, em grande extensão, a entrada do produto na atmosfera, deve-se tomar extremo cuidado na interpretação de dados de volatilização. A pressão de vapor de um pesticida pode dar uma boa estimativa do transporte de ar enquanto o produto estiver no estado livre ou estiver volatilizando de uma superfície inerte. De qualquer modo, quando o pesticida estiver ligado à superfície, a pressão de vapor não pode ser usada como um índice para o transporte de vapor (Taylor \& Spencer, 1990).

Quando se estuda a perda de vapor de uma superfície do solo, outros fatores como a temperatura, concentração inicial do pesticida, umidade e $\mathrm{pH}$ podem controlar a liberação do pesticida (Goellner, 1995). A elevação da temperatura na superfície do solo é um fator que intensifica a perda por volatilização dos pesticidas em geral. Da mesma forma, a intensificação dos ventos sobre a superfície tende a favorecer a volatilização pelo arrastamento dos vapores que se formam e reduzindo a sua concentração nas camadas junto ao solo. Teores mais baixos de água na camada superficial do solo favorecem a integração das moléculas de herbicida junto à fase sólida, pelos fenômenos de sorção reduzindo sua perda para a atmosfera. Se a temperatura se elevar bastante, a volatilização da água pode elevar a perda de pesticidas por arrastamento no fluxo ascendente de vapor. Por outro lado, moléculas de água competem com as dos pesticidas pelos mesmos sítios de sorção, podendo até deslocá-los em determinados casos (Taylor \& Spencer, 1990; Deuber, 1992). 


\section{INFLUÊNCIA DA MATÉRIA ORGÂNICA NA SORÇÃO E DESSORÇÃO DO GLIFOSATO EM SOLOS COM DIFERENTES ATRIBUTOS MINERALÓGICOS}

\section{Resumo}

O presente experimento objetivou estudar influência da matéria orgânica na sorção e dessorção do glifosato em três solos brasileiros com diferentes atributos mineralógicos. Os ensaios foram conduzidos no Laboratório de Ecotoxicologia do Centro de Energia Nuclear na Agricultura (CENA/USP), em Piracicaba, SP. Os solos foram classificados como: Nitossolo Vermelho Eutroférrico (NVef), Latossolo Amarelo Ácrico (LAw) e Gleissolo (G). Para avaliar a influência da matéria orgânica na sorção do glifosato, os solos foram oxidados com $\mathrm{H}_{2} \mathrm{O}_{2}$ (30\%). Os experimentos foram desenvolvidos utilizando-se o método "batch", em delineamento experimental inteiramente casualizado, com arranjo fatorial 3 × 2 (3 solos, com ou sem oxidação da matéria orgânica). Para a estipulação das isotermas de sorção, foram utilizadas 5 concentrações do herbicida: 0,$42 ; 0,84 ; 1,68 ; 3,36$ e $6,72 \mathrm{mg} \mathrm{L}^{-1}$, com radioatividade de $0,233 \mathrm{kBq} \mathrm{mL} L^{-1}$. Os estudos de dessorção foram realizados na concentração de $0,84 \mathrm{mg}$ $\mathrm{L}^{-1}$. Os resultados mostraram que o glifosato foi extremamente sorvido aos solos, independentemente da presença da matéria orgânica. Nestes solos, a sorção do glifosato foi relacionada principalmente à fração mineral, sendo que a fração orgânica desempenhou papel secundário. Não houve dessorção do glifosato, permanecendo a maior parte na forma de resíduo-ligado. 


\section{INFLUENCE OF SOIL ORGANIC MATTER ON THE SORPTION AND DESORPTION OF GLYPHOSATE IN SOILS WITH DIFFERENT MINERALOGICAL ATTRIBUTES}

\section{Summary}

The aim of this study was to evaluate the effects of soil organic matter on the sorption and desorption of glyphosate, in three soils with different mineralogical attributes. The experiments were carried out at laboratory of Ecotoxicology of the Centro de Energia Nuclear na Agricultura (CENA/USP), Piracicaba, SP (Brazil). The soils were classified as: Rhodic Kandiudalf (NVef), Anionic Acrudox (LAw) and Typic Humaquept (G). In order to evaluate the influence of organic matter on the ghyphosate sorption, soils were oxidized with $\mathrm{H}_{2} \mathrm{O}_{2}(30 \%)$. The sorption/desorption batch experiments were carried out in completely randomized design, with a $2 \times 3$ factorial experiment. In order to establish the sorption isotherms, five glyphosate solutions were employed with concentrations of $0.42,0.84,1.68,3.36$ and $6.72 \mathrm{mg} \mathrm{L}^{-1}$ and radioactivity of $0.233 \mathrm{kBq}$ $\mathrm{mL}^{-1}$. Desorption experiments were performed at concentration of $0.84 \mathrm{mg} \mathrm{L}^{-1}$. Results showed glyphosate was extremely sorbed to all soils, regardless of the presence of soil organic matter. The glyphosate sorption was related mainly to the mineral fraction of the soils. The organic fraction only played a secondary role. It was not observed glyphosate desorption, mostly forming soil bound-residues. 


\subsection{Introdução}

O glifosato [n-(fosfonometil)glicina] é o herbicida mais utilizado no mundo (Mendelson, 1998). Sua molécula foi descoberta em 1971 por J. E. Franz e introduzida comercialmente em 1974, na Europa, com o nome comercial de Round up (Grosbard \& Atkinson, 1986). No Brasil, este herbicida também tem sido amplamente utilizado, principalmente como dessecante em cultivos sob plantio direto, nas entrelinhas de culturas e na eliminação de plantas daninhas de ambientes aquáticos (Rodrigues \& Almeida, 1995).

O glifosato é um herbicida pertencente ao grupo químico dos derivados da glicina, e apresenta massa molecular igual a $169,1 \mathrm{~g}$, solubilidade em água $\left(S_{\mathrm{w}}\right)$ de $12 \mathrm{~g} \mathrm{~L}^{-1}$ a 25 ${ }^{\circ} \mathrm{C}$, pressão de vapor praticamente nula e capacidade de atuar como ácido fraco e base fraca ao mesmo tempo, o que o caracteriza como um "zwitterion" (Figura 1). Normalmente, o glifosato é aplicado em pós-emergência, apresentando ação total. Atua na inibição da enzima 5-enolpiruvishiquimato-3-fosfato sintetase (EPSPS), interferindo na biossíntese de aminoácidos (Roberts et al., 1998). Na maioria dos casos, este herbicida não é metabolizado pela planta, razão por que não apresenta seletividade. Somente variedades geneticamente alteradas para tal são resistentes ao glifosato. Desta forma, praticamente toda a concentração do ingrediente ativo aplicado chega ao solo na sua forma original.

\begin{tabular}{|c|c|c|}
\hline $\mathrm{HOOCCH}_{2} \stackrel{\oplus}{\mathrm{NH}_{2}} \mathrm{CH}_{2} \mathrm{PO}_{3} \mathrm{H}_{2}$ & $\stackrel{\mathrm{p} K_{b}}{\rightleftarrows}$ & $\mathrm{HOOCCH}_{2} \stackrel{\oplus}{\mathrm{NH}_{2}} \mathbf{C H}_{2} \mathrm{PO}_{3} \mathbf{H}+\underset{\mathbf{H}}{\oplus}$ \\
\hline $\mathrm{HOOCCH}_{2}{\stackrel{\Theta}{\mathrm{NH}_{2}}}_{\mathrm{CH}_{2}} \mathrm{PO}_{3} \mathrm{H}$ & $\stackrel{\mathrm{p} K_{31}}{\rightleftarrows}$ & 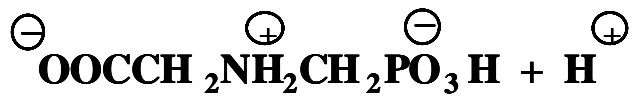 \\
\hline$\Theta_{\mathrm{OOCCH}_{2} \mathrm{NH}_{2} \mathrm{CH}_{2} \mathrm{PO}_{3} \mathrm{H}}^{\Theta}$ & $\stackrel{\mathrm{p} K_{22}}{\rightleftarrows}$ & $\bigoplus_{\mathrm{OOCCH}_{2} \mathrm{NH}_{2} \mathrm{CH}_{2} \mathrm{PO}_{3}}^{\ominus}$ \\
\hline 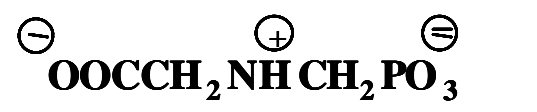 & $\stackrel{\mathrm{p} K_{33}}{\longrightarrow}$ & $\Theta_{\mathrm{OOCCH}_{2} \mathrm{NHCH}_{2} \mathrm{PO}_{3}}^{\ominus}$ \\
\hline
\end{tabular}

Figura 1. Esquema da especiação química do glifosato em função do $\mathrm{pH} . \mathrm{p} K_{\mathrm{b}}<2 ; \mathrm{p} K_{\mathrm{a} 1}=$ 2,27; $\mathrm{p} K_{\mathrm{a} 2}=5,57$ e $\mathrm{p} K_{\mathrm{a} 3}=10,86($ Franz, 1986). 
O comportamento do glifosato no solo é caracterizado pela sua alta capacidade de sorção e isotermas de sorção lineares, chegando a apresentar valores de coeficiente de sorção linear $\left(K_{\mathrm{d}}\right)$ da ordem de $1.188 \mathrm{~L} \mathrm{~kg}^{-1}$, para solos orgânicos (Cheah et al., 1997).

Vários mecanismos de ligação têm sido sugeridos para a sorção deste herbicida no solo. Para solos oxídicos, a ligação covalente entre um oxigênio de seu grupamento metilfosfônico e o átomo metálico dos óxidos têm sido o mecanismo mais sugerido (Cheah et al., 1997; Jonge et al., 2001). Piccolo et al. (1994), também faz menções a ligação covalente do glifosato com os óxidos de $\mathrm{Fe}$ e Al, sugerindo ainda que a formação deste mecanismo se dá por troca de ligantes. Por outro lado, Piccolo et al. (1996) evidenciaram as ligações de hidrogênio como sendo o principal mecanismo de ligação do glifosato com as substâncias húmicas. Os autores ainda observaram que, em moléculas húmicas de maior massa molecular e com cadeias carbônicas mais alifáticas, os valores dos coeficientes de sorção foram maiores.

De acordo com Jonge et al. (2001), a sorção do glifosato apresenta elevada energia de ligação, o que faz com que seja pouco extraída. A baixa extração do glifosato, decorrente da formação de resíduo-ligado, foi observada em vários trabalhos (Sprankle et al., 1975; Hance et al., 1976; Nomura \& Hilton, 1977; Cheah et al., 1997; Jonge et al., 2001). Na grande maioria dos casos, a baixa recuperação estava relacionada à capacidade dos solos em adsorver fosfatos.

A literatura mostra que a dissipação do glifosato, expressa através do valor de meia-vida $\left(t_{1 / 2}\right)$, varia bastante com o tipo de solo e deve-se, principalmente, a formação de resíduos-ligados. Normalmente, a meia-vida do glifosato é de cerca de 20 dias (Cheah et al., 1998). Entretanto, sua meia-vida de mineralização pode chegar a valores de até 22,7 anos para solos vulcânicos (Nomura \& Hilton, 1977).

Os estudos de comportamento do glifosato no solo são praticamente inexistentes para solos brasileiros. Desta forma, este trabalho teve como objetivo verificar a influência da matéria orgânica na sorção e dessorção do glifosato em amostras de três solos brasileiros com diferentes atributos mineralógicos. 


\subsection{Material e Métodos}

Os ensaios foram conduzidos no Laboratório de Ecotoxicologia do CENA/USP, Piracicaba, SP. Os experimentos de sorção e dessorção foram realizados em amostras de três solos, classificados como: Nitossolo Vermelho Eutroférrico (NVef), Latossolo Amarelo Ácrico (LAw) e Gleissolo (G). As amostras foram coletadas na profundidade de 0-20 cm nos municípios de Ribeirão Preto-SP, Guaíra-SP e Piracicaba-SP, respectivamente. Após a coleta, as amostras foram secas ao ar, passadas em peneira com malha de $2 \mathrm{~mm}$ e armazenadas no laboratório. Para avaliar a influência da matéria orgânica na sorção e dessorção do glifosato, os solos também tiveram sua fração orgânica destruída pela oxidação com $\mathrm{H}_{2} \mathrm{O}_{2}$ a $30 \%$ (Jackson, 1969). O delineamento experimental foi do tipo inteiramente casualizado, em arranjo fatorial 3 X 2 (3 solos, com e sem oxidação da matéria orgânica), com três repetições.

Os resultados das análises químicas e dos atributos granulométricos e mineralógicos estão descritos nas Tabelas 1 e 2, respectivamente. As análises químicas foram feitas de acordo com Raij \& Quaggio (1983), sendo que o teor de carbono orgânico foi determinado pelo método da combustão (Nelson \& Sommers, 1982). A análise granulométrica foi realizada de acordo com Camargo et al. (1986). O Fe total $\left(\mathrm{Fe}_{2} \mathrm{O}_{3}\right)$ e o Al total $\left(\mathrm{Al}_{2} \mathrm{O}_{3}\right)$ foram extraídos com $\mathrm{H}_{2} \mathrm{SO}_{4} 18$ mol L ${ }^{-1}$ (Jackson, 1969). Os minerais de argila predominantes foram identificados por difração de raios-X. Sub-amostras saturadas com $\mathrm{K}^{+}$foram irradiadas a 25,350 e $550{ }^{\circ} \mathrm{C}$. As saturadas com $\mathrm{Mg}^{2+}$ foram irradiadas na temperatura ambiente em duas etapas, antes e depois da solvatação com etileno-glicol, respectivamente. As frações caulinita e gibsita foram quantificadas por análise termodiferencial (ATD) (Jackson, 1969).

Os experimentos de sorção e dessorção foram realizados seguindo o método "batch". Para o desenvolvimento das isotermas de sorção, foram utilizadas cinco soluções com diferentes concentrações de glifosato: 0,$42 ; 0,84 ; 1,68 ; 3,36$ e $6,72 \mathrm{mg} \mathrm{L}^{-1}$. A concentração de $0,84 \mathrm{mg} \mathrm{L}^{-1}$, na relação solo: solução empregada (1: 5), correspondeu à dose máxima recomendada no campo. As soluções foram preparadas em $\mathrm{CaCh}$ 0,01 mol $\mathrm{L}^{-1}$, misturando o produto técnico (pureza $=96 \%$ ) com o seu isótopo radioativo $\left({ }^{14} \mathrm{C}\right.$ fosfonometil, pureza $=99 \%$ e atividade específica $=5,155 \mathrm{MBq} \mathrm{mg}^{-1}$ ). Nas diferentes soluções, a concentração radioativa correspondeu a $0,233 \mathrm{kBq} \mathrm{mL}^{-1}$. Amostras de $2 \mathrm{~g}$ de 
solo e alíquotas de $10 \mathrm{~mL}$ de solução foram acondicionados em tubos de centrífuga (50 $\mathrm{mL})$, em triplicata, os quais foram horizontalmente agitados (200 rpm) durante seis horas a $25 \pm 2{ }^{\circ} \mathrm{C}$. Subsequentemente, o conteúdo suspenso nos tubos foi centrifugado (3000 rpm, por $10 \mathrm{~min}$. ), retirando-se uma alíquota de $1 \mathrm{~mL}$ do sobrenadante para determinar a concentração de glifosato na solução de equilíbrio $\left(C_{\mathrm{e}}\right)$, por espectrometria de cintilação líquida (ECL). Para tal, assumiu-se que toda a radioatividade estaria na forma de glifosato. A quantidade sorvida ao solo foi determinada por diferença entre a concentração inicial e a concentração de equilíbrio.

Tabela 1. Características químicas dos solos Nitossolo Vermelho Eutroférrico (NVef), Latossolo Amarelo Ácrico (LAw) e Gleissolo (G)

\begin{tabular}{|c|c|c|c|c|c|c|c|c|c|}
\hline Solos & $\mathrm{pH}_{\mathrm{H} 2 \mathrm{O}}$ & $\mathrm{C}_{\text {org }}$ & $\mathrm{P}$ & $\mathrm{K}$ & $\mathrm{Ca}$ & $\mathrm{Mg}$ & $\mathrm{H}+\mathrm{Al}$ & $\mathrm{Al}$ & CTC \\
\hline & & $\mathrm{g} \mathrm{kg}^{-1}$ & $\mathrm{mg} \mathrm{kg}^{-1}$ & \multicolumn{6}{|c|}{. } \\
\hline NVef & 6,1 & 27,5 & 6 & 3,6 & 74 & 28 & 59 & 2 & 164,6 \\
\hline LAw & 5,5 & 18,9 & 90 & 1,4 & 3 & 3 & 36 & 6 & 43,6 \\
\hline G & 4,2 & 78,5 & 17 & 3,9 & 13 & 8 & 380 & 88 & 404,9 \\
\hline
\end{tabular}

Tabela 2. Atributos granulométricos e mineralógicos dos solos Nitossolo Vermelho Eutroférrico (NVef), Latossolo Amarelo Ácrico (LAw) e Gleissolo (G).

\begin{tabular}{|c|c|c|c|c|c|c|c|c|c|}
\hline \multirow[t]{3}{*}{ Solos } & \multicolumn{3}{|c|}{ Atributos granulométricos } & \multicolumn{6}{|c|}{ Atributos mineralógicos } \\
\hline & Areia & Silte & Argila & $\mathrm{Al}_{2} \mathrm{O}_{3}$ & $\mathrm{Fe}_{2} \mathrm{O}_{3}$ & & ineral & de argil & \\
\hline & \multicolumn{3}{|c|}{................... $\mathrm{g} \mathrm{kg}^{-1}$} & \multicolumn{2}{|c|}{.......... $\mathrm{g} \mathrm{kg}^{-1} \ldots \ldots \ldots . .}$. & $\mathrm{Cau}^{1 /}$ & $\mathrm{Gb}^{2 /}$ & $\mathrm{VHI}^{3 /}$ & $\mathrm{V}^{4 \prime}$ \\
\hline NVef & 250 & 200 & 550 & 183 & 298 & +++++ & + & - & - \\
\hline LAw & 590 & 60 & 350 & 113 & 59 & ++++ & ++ & - & - \\
\hline G & 200 & 260 & 540 & - & - & ++++ & + & + & ++ \\
\hline
\end{tabular}

${ }^{1 /}$ Caulinita, ${ }^{2 /}$ Gibsita, ${ }^{3 /}$ Vermiculita com hidroxila nas intercamadas, ${ }^{4 /}$ Vermiculita, +,++++ Proporção dos minerais de argila 
Para o estudo de dessorção, os sobrenadantes dos tubos de centrífuga foram descartados e alíquotas de $10 \mathrm{~mL}$ de solução de $\mathrm{CaCh}_{0}$ 0,01 mol L $\mathrm{L}^{-1}$ (sem o herbicida) foram adicionadas somente à concentração de $0,84 \mathrm{mg} \mathrm{L}^{-1}$. Posteriormente, os tubos foram agitados, centrifugados e o novo sobrenadante foi descartado da mesma forma que no teste de sorção. Tal procedimento foi repetido por mais três vezes, após o qual as amostras de solo foram secas ao ar, homogeneizadas e sub-amostras $(0,4 \mathrm{~g})$ foram retiradas para determinar, por ECL após combustão em oxidador biológico, a radioatividade sorvida ao solo. Isto permitiu o fechamento do balanço de massa radioativa.

Aos resultados das isotermas de sorção foi ajustado o modelo matemático de Freundlich:

$$
S=K_{f} C_{e}^{N}
$$

em que $S=$ concentração de glifosato sorvido $\left(\mu \mathrm{g} \mathrm{g}^{-1}\right), C_{\mathrm{e}}=$ concentração de glifosato na solução de equilíbrio $\left(\mu \mathrm{g} \mathrm{mL}^{-1}\right), K_{\mathrm{f}}=$ coeficiente de Freundlich para sorção e $N=$ grau de linearidade da isoterma.

Para fins de comparação, estudos de análise de variância foram realizados para os valores de $S, C_{\mathrm{e}}$ e $K_{\mathrm{f}}$. Valores da diferença mínima significativa (DMS) foram calculados pelo teste de Tukey $(\mathrm{p}<0,05)$.

\subsection{Resultados e Discussão}

Os resultados obtidos por meio dos estudos de isotermas de sorção/dessorção, baseados na equação de Freundlich, são apresentados na Tabela 3. Pelos valores de $\mathrm{R}^{2}$, pode-se observar que o modelo de Freundlich ajustou-se adequadamente aos dados deste estudo. Pode-se também observar que o glifosato foi altamente sorvido em todos os solos mesmo após a eliminação da matéria orgânica ( $\mathrm{S} \geq 84,7 \%$, Tabela 3). Pela análise estatística, entretanto, com exceção ao Nitossolo, a sorção do glifosato foi sempre menor nas amostras de solo sem a matéria orgânica, sendo a diferença um pouco mais pronunciada para o Gleissolo (Tabela 3). A elevada capacidade de sorção do glifosato também foi observada em outro trabalhos (Nomura \& Hilton, 1977; Glass, 1987; Cheah et al., 1997; Jonge et al., 2000; Jonge et al., 2001). 
Tabela 3. Parâmetros das isotermas de sorção e dessorção do glifosato nos solos Nitossolo Vermelho Eutroférrico (NVef e NVefox.), Latossolo Amarelo Ácrico (LAw e LAw-ox.) e Gleissolo (G e Gox.), com (ox.) e sem a oxidação da matéria orgânica, respectivamente

\begin{tabular}{|c|c|c|c|c|c|c|c|c|c|}
\hline Solo & $S^{1 /}$ & $S^{2 /}$ & $C_{e}^{3 /}$ & $C_{e}^{2 /}$ & $D^{4 /}$ & $K_{f}$-sor $^{5 /}$ & $N$ & $\mathrm{R}^{2}$ & $K_{f}-\operatorname{des}^{6 /}$ \\
\hline & $\ldots \mu \mathrm{g} \mathrm{g}^{-1} \ldots$ & $\ldots \% \ldots$ & $\ldots . \mu \mathrm{g} \mathrm{mL}^{-1} \ldots$. & $\ldots \% \ldots$ & $\ldots \mu \mathrm{g} \mathrm{g}^{-1} \ldots$ & $\ldots \ldots \mathrm{L} \mathrm{kg}^{-1} \ldots \ldots$ & & & $\ldots . \mathrm{L} \mathrm{kg}^{-1} \ldots$. \\
\hline NVef & $4,12 \pm 0,020$ & 97,4 & $0,022 \pm 0,0002$ & 2,60 & $0 \pm 0,0$ & $169,0 \pm 1,5$ & 0,97 & $1,00 * *$ & $\mathrm{ND}^{7 /}$ \\
\hline NVef-ox. & $4,06 \pm 0,008$ & 96,5 & $0,029 \pm 0,0014$ & 3,45 & $0 \pm 0,0$ & $168,5 \pm 0,7$ & 1,02 & $0,99 * *$ & ND \\
\hline LAw & $4,14 \pm 0,001$ & 97,8 & $0,018 \pm 0,0011$ & 2,13 & $0 \pm 0,0$ & $243,5 \pm 21,8$ & 1,01 & $0,99 * *$ & ND \\
\hline LAw-ox. & $4,06 \pm 0,017$ & 96,5 & $0,029 \pm 0,0028$ & 3,45 & $0 \pm 0,0$ & $198,3 \pm 1,9$ & 1,05 & $0,99 * *$ & ND \\
\hline $\mathrm{G}$ & $4,12 \pm 0,009$ & 97,6 & $0,020 \pm 0,0007$ & 2,37 & $0 \pm 0,0$ & $228,3 \pm 10,6$ & 1,02 & $0,99 * *$ & ND \\
\hline G-ox. & $3,55 \pm 0,014$ & 84,7 & $0,128 \pm 0,0077$ & 15,27 & $0 \pm 0,0$ & $31,7 \pm 1,8$ & 1,02 & $0,99 * *$ & ND \\
\hline
\end{tabular}

\begin{tabular}{lllllll}
\hline $\mathrm{DMS}^{8 /}$ & 0,044 & - & 0,0056 & - & 17,61 & - \\
\hline
\end{tabular}

${ }^{1 /}$ Glifosato sorvido (dados para concentração de $0,84 \mathrm{mg} \mathrm{L}^{-1}$ ). ${ }^{2 /}$ Porcentagem em relação ao total aplicado. ${ }^{3 /}$ Glifosato na solução de equilíbrio. ${ }^{4 /}$ Total dessorvido. ${ }^{5 /}$ Coeficiente de Freundlich para sorção. ${ }^{6 /}$ Coeficiente de Freundlich para dessorção. ${ }^{7 /}$ ND = não determinável. ${ }^{8 /}$ Diferença mínima significativa pelo teste de Tukey $(\mathrm{p}<0,05)$. 
Sabe-se que a molécula do glifosato apresenta alta solubilidade em água (12 g $\mathrm{L}^{-1}$ ), sendo praticamente insolúvel em solventes orgânicos. Trata-se, portanto, de uma substância com baixa hidrofobicidade $\left(\log K_{\mathrm{ow}}=-4,1\right)$, que ao contrário do normalmente esperado, apresenta elevada sorção.

Com base nos elevados valores de $K_{\mathrm{f}}$ observados nestes três solos (Tabela 3), mesmo após a eliminação da matéria orgânica, verifica-se que a sorção do glifosato está relacionada, principalmente, com a fração mineral destes solos. Portanto, a sorção do glifosato nestes solos, provavelmente, está relacionada a mecanismos específicos de ligação com a fração mineral, envolvendo elevada energia de ligação, e não a mecanismos de partição hidrofóbica.

Vários trabalhos na literatura demonstram que a extensão da sorção do glifosato é diretamente proporcional à capacidade do solo em adsorver fosfato inorgânico e à presença de ions de $\mathrm{Fe}^{2+}, \mathrm{Fe}^{3+}$ e $\mathrm{Al}^{3+}$ (Glass, 1987; Miles \& Moye, 1988; Gerritse, 1996; Jonge et al., 2001). Além do mais, não tem sido observada correlação entre o teor de matéria orgânica do solo e a sorção do glifosato.

Neste estudo, para os solos ricos em óxidos, casos do NVef e LAw, a oxidação da matéria orgânica, embora estatisticamente tenha reduzido a sorção do glifosato no LAw, do ponto de vista prático não interferiu na sua sorção (Tabelas 2 e 3). Isto é, embora a oxidação da matéria orgânica denote diferença estatística entre os valores de $K_{f}$-sor para este solo, esta diferença não é refletida pelos valores percentuais de $S$ (Tabela 3). Desta forma, acredita-se que os óxidos de Fe e Al sejam os principais responsáveis pela sorção dessa molécula nestes dois solos. Por outro lado, o fato do Gleissolo ter apresentado maior redução no valor de $K_{\mathrm{f}}$-sor com a eliminação da matéria orgânica (Tabela 3), indica que a fração orgânica do solo também pode influenciar, mesmo que seja de forma secundária, a sorção do glifosato em solos com baixos teores de óxidos de $\mathrm{Fe}$ e Al.

Pelas observações acima e de acordo com a literatura, vários mecanismos de ligação podem estar atuando concomitantemente na sorção do glifosato. Nos valores de $\mathrm{pH}$ desses solos, o glifosato pode manifestar tanto carga positiva quanto negativa, atuando como um "zwitterion", o que poderia contribuir para sua sorção via ligações 
eletrostáticas. Jonge et al. (2001) sugeriram que há adsorção iônica do glifosato, mesmo em condições de $\mathrm{pH}$ em que a molécula apresente balanço negativo de cargas. Eles fundamentaram a sugestão pelo fato da adsorção do $\mathrm{Ca}^{2+}$ poder aumentar a sorção do glifosato. Por outro lado, Cheah et al. (1997) sugeriram as ligações covalentes, induzidas pela troca de ligantes, como um dos prováveis mecanismos de ligação do glifosato, não levando em conta o fato da molécula ser um "zwitterion".

$\mathrm{O}$ efeito dos óxidos de $\mathrm{Fe}$ e $\mathrm{Al}$ na elevada orção do glifosato também foi observado por Piccolo et al. (1994) e Gerritse (1996). Para os autores, a troca de ligantes poderia estar atuando na manifestação de um mecanismo de ligação mais estável, como a ligação covalente. Adicionalmente, Piccolo et al. (1996) estudaram a sorção do glifosato em substâncias húmicas e verificaram valores de $K_{f}$ inferiores aos obtidos nesse trabalho, embora ainda altos. Tais valores foram atribuídos às ligações de hidrogênio entre a molécula e as substâncias húmicas, sendo que para moléculas húmicas de maior massa molecular e com cadeias carbônicas mais alifáticas, os valores de $K_{f}$ foram maiores. De acordo com Piccolo et al. (1996), o fato da molécula do glifosato possuir grupos que podem servir como doadores e receptores de prótons e as substâncias húmicas também possuírem grupos funcionais contendo oxigênio, por si só, sugere as ligações de hidrogênio como um possível mecanismo de ligação.

Os valores de $N$ (Tabela 3), obtidos pelo modelo de Freundlich, mostraram isotermas de sorção lineares para todos os solos, com e sem oxidação da matéria orgânica. Isto significa que, para as concentrações de glifosato empregadas neste estudo, sua sorção independeu da concentração. Todavia, a diferença entre as concentrações mínima e máxima utilizadas no presente estudo foi de apenas 16 vezes. Quando Jonge et al. (2001) aumentaram essa diferença para 1600 vezes, as isotermas de sorção do glifosato não foram lineares, apresentando valores de $N$ entre 0,5 e 0,7 .

Após a realização dos experimentos de dessorção, não foi observada a liberação da molécula em nenhum dos tratamentos (Tabela 3). Este comportamento imóvel do glifosato estaria, provavelmente, relacionado aos altos valores de $K_{f}$. Além disso, o uso de solução aquosa salina $\left(\mathrm{CaCh}_{2}, 01 \mathrm{~mol} \mathrm{~L}^{-1}\right)$ para dessorver o glifosato do solo reflete a sua capacidade máxima de extração, uma vez que o glifosato é insolúvel em solventes 
orgânicos. Assim sendo, pode-se inferir que praticamente a totalidade do glifosato aplicado ao solo permaneceu na forma de resíduo-ligado.

Quando se desconsidera o fenômeno de precipitação do fósforo, o comportamento do glifosato neste experimento (elevada sorção e nenhuma extração) pode ser considerado semelhante ao comportamento dos fosfatos em solos oxídicos (Tan, 1993). Grande parte do $\mathrm{P}$ aplicado a solos oxídicos, como fertilizante, sofre adsorção específica. Isto é, ocorre a ligação covalente dativa (dupla) entre um oxigênio do íon fosfato e o átomo metálico do óxido (Tan, 1993). O P adsorvido desta forma não pode ser extraído por extratores convencionais, permanecendo numa forma chamada de não-lábil, a qual pode ser um sinônimo do termo resíduo-ligado, usado para moléculas orgânicas. Isto sugere que, para solos oxídicos, os fosfatos inorgânicos poderiam competir com o glifosato por sítios específicos de sorção.

Como o glifosato praticamente não é metabolizado pelas plantas (Roberts et al., 1998), grande parte chega ao solo na sua forma original e, em solos onde seu potencial de sorção é elevado, como os empregados ne ste estudo, pode predominar sua forma de resíduo-ligado. O fato desta forma não ser contabilizada nos estudos a campo, com técnicas não radioativas, e, na maioria das vezes, ser muito pouco degradada (Steen et al., 1980), merece atenção em futuros estudos.

\subsection{Conclusões}

O glifosato foi extremamente sorvido aos solos, mesmo após a destruição da matéria orgânica.

A sorção do glifosato está relacionada principalmente à fração mineral destes solos, sendo que a fração orgânica desempenha papel secundário.

Não houve dessorção do glifosato, o qual permaneceu nos solos na forma de resíduo-ligado. 


\section{SORÇÃO E DESSORÇÃO DE GLIFOSATO EM SOLOS COM NÍVEIS CRESCENTES DE FÓSFORO}

\section{Resumo}

O presente estudo teve o objetivo de verificar a extensão do efeito de níveis crescentes de fósforo no solo na sorção e dessorção do glifosato em três solos com diferentes atributos mineralógicos. Os ensaios foram conduzidos no Laboratório de Ecotoxicologia do Centro de Energia Nuclear na Agricultura (CENA/USP), em Piracicaba, SP. Os solos foram classificados como: Nitossolo Vermelho Eutroférrico (NVef), Latossolo Amarelo Ácrico (LAw) e Gleissolo (G). Para tal, amostras dos solos foram incubadas com $\mathrm{KH}_{2} \mathrm{PO}_{4}$, por 30 dias, nas doses equivalentes a $0 ; 1000 ; 5000$;

20000 e $50000 \mathrm{~kg} \mathrm{ha}^{-1}$ de $\mathrm{P}_{2} \mathrm{O}_{5}$, para posteriormente realizar os experimentos de sorção e dessorção através do método "batch". O delineamento experimental empregado foi do tipo inteiramente casualizado, em arranjo fatorial 3 (solos) x 5 (níveis de fósforo no solo), com três repetições. Para o estabelecimento das isotermas de sorção, foram utilizadas 5 concentrações do herbicida: 0,$42 ; 0,84 ; 1,68 ; 3,36$ e $6,72 \mathrm{mg} \mathrm{L}^{-1}$, com radioatividade de $0,233 \mathrm{kBq} \mathrm{mL}^{-1}$. Foram realizadas quatro dessorções com $\mathrm{CaCl}$ 0,01 mol L $\mathrm{L}^{-1}$ e uma extração com extrator Mehlich 3. Posteriormente, alíquotas do solo foram oxidadas em oxidador biológico para o fechamento do balanço de radioatividade. Os resultados mostraram que o glifosato compete com o fósforo pelos sítios de sorção específica no solo, mas essa competição somente passa a ser importante quando os níveis de $\mathrm{P}$ no solo atingem valores superiores a $1000 \mathrm{mg} \mathrm{dm}^{-3}$. $\mathrm{O}$ glifosato foi pouco extraído $(<10 \%)$ e a extração foi acrescida com aumento dos níveis de P no solo. 


\section{GLYPHOSATE SORPTION AND DESORPTION IN SOILS WITH INCREASING RATES OF PHOSPHORUS}

\section{Summary}

The aim of this study was to evaluate the effects of increasing rates of phosphorus on the sorption and desorption of glyphosate in three soils with different mineralogical attributes. The experiments were carried out at laboratory of Ecotoxicology of the Centro de Energia Nuclear na Agricultura (CENA/USP), Piracicaba, SP (Brazil). The soils were classified as Rhodic Kandiudalf (NVef), Anionic Acrudox (LAw) and Typic Humaquept (G). The soil samples were amended with $\mathrm{KH}_{2} \mathrm{PO}_{4}$ at equivalent rates of $0 ; 1,000 ; 5,000 ; 20,000$ and $50,000 \mathrm{~kg} \mathrm{ha}^{-1}$ of $\mathrm{P}_{2} \mathrm{O}_{5}$, in order to subsequently perform sorption and desorption batch experiments. Design was completely randomized, in 3 (soils) x 5 (phosphorus rates in soils) factorial, with 3 replicates. In order to establish the sorption isotherms, five glyphosate solutions were employed $\left(0.42,0.84,1.68,3.36\right.$ and $\left.6.72 \mathrm{mg} \mathrm{L}^{-1}\right)$, with a radioactive concentration of $0.233 \mathrm{kBq} \mathrm{mL}^{-1}$. Four desorption steps using $\mathrm{CaCh}_{0}, 01 \mathrm{~mol} \mathrm{~L}^{-1}$ and one extraction with Mehlich 3 extractor solution were performed. Afterwards, soil samples were oxidized in biological oxidizer to establish radioactive balance. Results showed glyphosate competes with phosphorus for specific sorption sites. However, this competition becomes important when the phosphorus rates are higher than $1,000 \mathrm{mg} \mathrm{dm}^{-3}$. A small amount of sorbed glyphosate was extracted $(<10 \%)$, being the extraction increased with phosphorus content increasing in the soils. 


\subsection{Introdução}

O glifosato [n(fosfonometil)glicina], ingrediente ativo do Round up ${ }^{\circledR}$, o herbicida mais vendido no mundo (Mendelson, 1998), é uma molécula não seletiva amplamente utilizada no Brasil como dessecante em cultivos sobre plantio direto, nas entrelinhas de culturas perenes e na eliminação de plantas daninhas de ambientes aquáticos (Rodrigues \& Almeida, 1995).

O principal mecanismo de ação do glifosato nas plantas está relacionado à interferência na biossíntese de aminoácidos, pela inibição da enzima 5enolpiruvishiquimato-3-fosfato sintetase (EPSPS) (Roberts et al., 1998). Entretanto, sua ação herbicida ocorre somente quando a aplicação é realizada em pós-emergência. Quando o glifosato é aplicado diretamente ao solo, sua ação herbicida é praticamente nula (Sprankle et al., 1975). A inatividade do glifosato no solo se deve a sua elevada sorção, a qual chega a apresentar valores de coeficiente de sorção linear $\left(K_{d}\right)$ da ordem de $1.188 \mathrm{~L} \mathrm{~kg}^{-1}$ (Cheah et al., 1997).

A sorção do glifosato vem sendo há tempos estudada (Sprankle et al., 1975; Hance, 1976) e vários mecanismos de ligação têm sido sugeridos para explicar as elevadas taxas de sorção desta molécula.

Miles \& Moye (1988) verificaram um aumento na sorção do glifosato com o decréscimo do $\mathrm{pH}$ e sugeriram as ligações eletrostáticas como sendo o principal mecanismo de ligação da molécula para minerais de argila 2:1, em meios extremamente ácidos. Por outro lado, Piccolo et al. (1996) evidenciaram as ligações de hidrogênio como o principal mecanismo de sorção do glifosato com as substâncias húmicas. Os autores ainda observaram que, em moléculas húmicas de maior massa molecular e com cadeias carbônicas mais alifáticas, os valores dos coeficientes de sorção foram maiores.

Prata et al. (2000b) estudaram a influência da matéria orgânica na sorção e dessorção do glifosato, em três solos com diferentes atributos mineralógicos. Eles verificaram que a sorção desse herbicida se relacionou, principalmente, com a fração mineral desses solos, sendo que matéria orgânica apenas desempenhou papel secundário. Nesse trabalho também foi verificado que a molécula não pôde ser extraída, 
permanecendo no solo como resíduo-ligado. Para sistemas contendo os íons $\mathrm{Fe}^{2+}$ ou $\mathrm{Al}^{3+}$, ou mesmo para solos oxídicos, como a maioria dos solos utilizados por Prata et al. (2000b), vários autores têm sugerido a ligação covalente entre um oxigênio do grupamento metilfosfônico do glifosato e o átomo metálico dos óxidos como o principal mecanismo de ligação (Piccolo et al., 1994; Cheah et al., 1997; Jonge et al., 2001). Segundo Piccolo et al. (1994), esta ligação covalente pode estar sendo gerada pela troca de ligantes e deve ser o mesmo processo que envolve a adsorção específica de fosfatos inorgânicos no solo.

A relação entre a sorção do glifosato e a capacidade dos solos em adsorver fosfatos já foi abordada na literatura (Sprankle et al., 1975; Hance, 1976; Glass, 1987; Miles \& Moye, 1988; Gerritse et al., 1996; Jonge \& Jonge, 1999; Jonge et al., 2001). Por exemplo, Sprankle et al. (1975) verificaram que a sorção do glifosato no solo estava relacionada a seu grupamento metilfosfônico e que competia com os fosfatos inorgânicos pelos sítios de sorção. Eles observaram que a aplicação de 98 ou $196 \mathrm{~kg} \mathrm{ha}^{-1}$ de $\mathrm{P}_{2} \mathrm{O}_{5}$ contribuía para a menor inativação do glifosato no solo. Adicionalmente, Hance (1976) observaram correlação entre a sorção do glifosato e o número de sítios de sorção específica para fosfatos e concluíram que a presença de fosfatos inorgânicos excluía o glifosato dos sítios de sorção.

A adsorção competitiva entre o glifosato e os fosfatos inorgânicos também tem sido motivo de interesse em estudos recentes (Jonge \& Jonge, 1999; Jonge et al., 2001). Ao contrário dos trabalhos mais antigos, Jonge et al. (2001) mostraram, de forma direta, a redução da sorção do glifosato num solo arenoso, na presença de fosfato inorgânico. Muito embora este efeito tenha sido somente em peque na escala.

A extensão da adsorção competitiva entre o glifosato e o $\mathrm{P}$ inorgânico ainda não está bem esclarecida, principalmente para os solos brasileiros com alta capacidade de adsorção de fosfatos, como os solos ácricos. Neste sentido, este capítulo tem o objetivo verificar a extensão do efeito de níveis crescentes de P no solo na sorção e dessorção do glifosato em solos com diferentes atributos mineralógicos. 


\subsection{Material e Métodos}

Os ensaios foram conduzidos no laboratório de Ecotoxicologia do CENA/USP, Piracicaba, SP, sendo os experimentos realizados em amostras de três solos, classificados como: Nitossolo Vermelho Eutroférrico (NVef), Latossolo Amarelo Ácrico (LAw) e Gleissolo (G). As amostras foram coletadas na profundidade de $0-20 \mathrm{~cm}$, nos municípios de Ribeirão Preto-SP, Guaíra-SP e Piracicaba-SP, respectivamente. Após a coleta, as amostras de solo foram secas ao ar, passadas em peneira com malha de $2 \mathrm{~mm}$ e armazenadas no laboratório. Os resultados das análises químicas e dos atributos granulométricos e mineralógicos estão descritos nas tabelas 1 e 2, respectivamente. As análises químicas foram feitas de acordo com Raij \& Quaggio (1983), sendo que o teor de carbono orgânico foi determinado pelo método da combustão (Nelson e Sommers, 1982). As análises granulométricas foram realizadas de acordo com Camargo et al. (1986). O Fe total $\left(\mathrm{Fe}_{2} \mathrm{O}_{3}\right)$ foi extraído com $\mathrm{HSO}_{4} 18$ mol L $\mathrm{L}^{-1}$ (Jackson, 1969). Os minerais de argila predominantes foram determinados por difração de raios-X. Para tanto, sub-amostras saturadas com $\mathrm{K}^{+}$foram irradiadas a 25,350 e $550{ }^{\circ} \mathrm{C}$. As saturadas com $\mathrm{Mg}^{2+}$ foram irradiadas na temperatura ambiente em duas etapas, antes e depois da solvatação com etileno-glicol, respectivamente. As frações caulinita e gibsita foram quantificadas por análise termo-diferencial (ATD) (Jackson, 1969).

O delineamento experimental empregado foi do tipo inteiramente casualizado em arranjo fatorial 3 (solos) X 5 (níveis de fósforo no solo), com três repetições.

Para que os teores de fósforo nos solos atingissem os níveis desejados, as amostras de cada solo foram incubadas com $\mathrm{KH}_{2} \mathrm{PO}_{4}$, em béquer de $500 \mathrm{~mL}$, com doses equivalentes a 0; 1000; 5000; 20000 e $50000 \mathrm{~kg} \mathrm{ha}^{-1}$ de $\mathrm{P}_{2} \mathrm{O}_{5}$. Para base de cálculo, considerourse a densidade dos solos igual $1 \mathrm{~g} \mathrm{~cm}^{-3}$ e profundidade de $0,20 \mathrm{~m}$. O período de incubação adotado para reação do $\mathrm{KH}_{2} \mathrm{PO}_{4}$ nos solos foi de 30 dias, sendo que a umidade dos solos foi mantida à $60 \%$ da capacidade de campo. Posteriormente ao período de incubação, as amostras foram secas ao ar, destorroadas e novamente passadas em peneira com malha de $2 \mathrm{~mm}$ para verificação dos níveis atingidos de $\mathrm{P}$, condutividade elétrica e $\mathrm{pH}$ (Tabela 4). As análises de $\mathrm{P}$ e $\mathrm{pH}$ foram procedidas de 
acordo com Raij \& Quaggio (1983) e a condutividade elétrica foi determinada por condutivimetria (largura de célula de $1 \mathrm{~cm}$ ), para então serem realizados os ensaios de sorção e dessorção.

Os experimentos de sorção e dessorção foram desenvolvidos seguindo o método "batch". Para realização do estudo de isotermas, foram utilizadas cinco soluções com diferentes concentrações de glifosato: 0,$42 ; 0,84 ; 1,68 ; 3,36$ e $6,72 \mathrm{mg} \mathrm{L}^{-1}$. A concentração de $0,84 \mathrm{mg} \mathrm{L}^{-1}$, na relação solo: solução empregada (1: 5), correspondeu à dose máxima recomendada no campo. As soluções foram preparadas em $\mathrm{CaCh}$ 0,01 mol $\mathrm{L}^{-1}$, misturando-se o produto técnico (pureza $=96 \%$ ) com o seu isótopo radioativo $\left({ }^{14} \mathrm{C}\right.$ fosfonometil, pureza $=99 \%$ e atividade específica $=5,155 \mathrm{MBq} \mathrm{mg}^{-1}$ ). Nas diferentes soluções, a concentração radioativa correspondeu a $0,233 \mathrm{kBq} \mathrm{mL}^{-1}$. Amostras de $2 \mathrm{~g}$ de solo e alíquotas de $10 \mathrm{~mL}$ de solução foram acondicionados em tubos de centrífuga (50 $\mathrm{mL}$ ), em triplicatas, os quais foram agitados horizontalmente (200 rpm) durante 6 horas a $25 \pm 2{ }^{\circ} \mathrm{C}$. Subseqüentemente, o conteúdo suspenso nos tubos foi centrifugado (3000 rpm, por $10 \mathrm{~min}$. ), retirando-se uma alíquota de $1 \mathrm{~mL}$ do sobrenadante para determinar, por espectrometria de cintilação líquida (ECL), a radioatividade na solução de equilíbrio. Utilizando-se a atividade específica do ${ }^{14} \mathrm{C}$-glifosato, pôde-se calcular a concentração do herbicida nas soluções de equilíbrio. Para tal, assumiu-se que toda a radioatividade estaria na forma de glifosato. A concentração sorvida ao solo foi determinada por diferença entre a concentração inicial e a concentração de equilíbrio.

Para o estudo de dessorção, os sobrenadantes dos tubos de centrífuga foram descartados e alíquotas de $10 \mathrm{~mL}$ de solução de $\mathrm{CaCb}_{0}$ 0,01 mol L $\mathrm{L}^{-1}$ (sem o herbicida) foram adicionadas somente à concentração de $0,84 \mathrm{mg} \mathrm{L}^{-1}$. Posteriormente, os tubos foram agitados, centrifugados e o novo sobrenadante foi descartado da mesma forma que no teste de sorção. Este procedimento foi repetido por mais três vezes. Seqüencialmente, foi realizada uma tentativa de extração adicionando-se $10 \mathrm{~mL}$ de solução extratora "Mehlich 3" (Mehlich, 1984). A solução extratora "Mehlich 3" é utilizada para extração

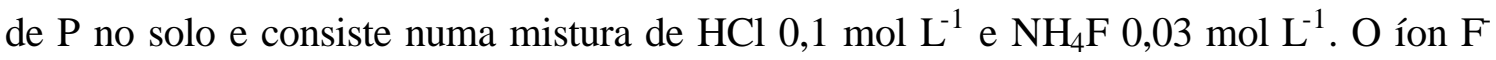
presente no extrator atua na complexação do $\mathrm{AP}^{3+}$ e do $\mathrm{Ca}^{2+}$ na solução do solo, fazendo com que o P precipitado seja solubilizado e, assim, possa ser determinado. A solução 
"Mehlich 3" foi empregada no presente estudo por assumirmos que o grupamento metilfosfônico do glifosato pode apresentar comportamento no solo semelhante ao dos fosfatos inorgânicos.

No final desta etapa, as amostras de solo foram secas ao ar, homogeneizadas e sub-amostras $(0,4 \mathrm{~g})$ foram retiradas e oxidadas em oxidador biológico para se determinar, por ECL, a radioatividade sorvida ao solo. Isto permitiu o fechamento do balanço de massa radioativa.

Tabela 4. Doses de $\mathrm{P}_{2} \mathrm{O}_{5}$ aplicadas, níveis de $\mathrm{P}$, condutividade elétrica $(\mathrm{CE})$ e $\mathrm{pH}$ atingidos após 30 dias da incubação nos solos Nitossolo Vermelho Eutroférrico (NVef), Latossolo Amarelo Ácrico (LAw) e Gleissolo (G)

\begin{tabular}{|c|c|c|c|c|}
\hline Unidade de solo & P aplicado & $\mathrm{P}$ & $\overline{\mathrm{CE}}$ & $\mathrm{pH}_{\mathrm{H} 2 \mathrm{O}}$ \\
\hline & $\mathrm{kg} \mathrm{P}_{2} \mathrm{O}_{5} \mathrm{ha}^{-1}$ & $\mathrm{mg} \mathrm{dm}^{-3}$ & $\mathrm{mS} \mathrm{cm}^{-1}$ & \\
\hline \multirow[t]{5}{*}{ NVef } & 0 & 20 & 0,532 & 6,1 \\
\hline & 1000 & 208 & 0,605 & 6,2 \\
\hline & 5000 & 1051 & 0,768 & 6,2 \\
\hline & 20000 & 4286 & 2,740 & 6,4 \\
\hline & 50000 & 10799 & 9,890 & 6,4 \\
\hline \multirow[t]{5}{*}{ LAw } & 0 & 10 & 0,269 & 5,5 \\
\hline & 1000 & 211 & 0,435 & 5,7 \\
\hline & 5000 & 1009 & 0,784 & 5,9 \\
\hline & 20000 & 4250 & 3,080 & 5,8 \\
\hline & 50000 & 10622 & 8,910 & 5,9 \\
\hline \multirow[t]{5}{*}{$\mathrm{G}$} & 0 & 36 & 0,262 & 4,2 \\
\hline & 1000 & 223 & 0,372 & 4,5 \\
\hline & 5000 & 1030 & 0,635 & 4,6 \\
\hline & 20000 & 4313 & 2,120 & 4,6 \\
\hline & 50000 & 10819 & 9,770 & 4,8 \\
\hline
\end{tabular}


Aos resultados de sorção e dessorção foi ajustado o modelo matemático de Freundlich para isotermas (eq. 28).

Foram realizadas análises de regressão entre os níveis crescentes de $\mathrm{P}$ nos solos e as constantes de Freundlich $\left(K_{f}\right)$, assim como com a porcentagem total sorvida. Análises de variância e testes de comparação de média (Tukey, $\mathrm{p}<0,05$ ) foram efetuados para as porcentagens de glifosato extraídas e dessorvidas.

\subsection{Resultados e Discussão}

A sorção do glifosato nos três solos estudados foi influenciada pelo nível de $\mathrm{P}$ nos solos, sendo que a quantidade sorvida de glifosato começou a ser reduzida substancialmente a partir de níveis de $1000 \mathrm{mg} \mathrm{dm}^{-3}$ de P (Figura 2). Entretanto, essa visualização da redução na sorção do glifosato perde importância prática, pois esses níveis de fósforo nunca seriam atingidos em condições normais de campo para solos agricultáveis. Portanto, nessa condição a competição entre o glifosato e o P pelos sítios de ligação covalente no solo não deve ocorrer. No entanto, esses resultados vem a confirmar que a extensão das forças de ligação do glifosato é proporcional a capacidade do solo em adsorver fosfato inorgânico, como salientado por outros autores (Hance, 1976; Glass, 1987; Miles \& Moye, 1988; Gerritse et al., 1996; Jonge \& Jonge, 1999; Jonge et al., 2001), sugerindo a importância da ligação covalente entre o grupo metilfosfônico do glifosato e os metais dos óxidos do solo.

Pela relação obtida entre a sorção do glifosato e os níveis de P no solo através da análise de regressão (Figura 2), com os conteúdos de fósforo no solo em torno de 6871, 5023 e $9744 \mathrm{mg} \mathrm{dm}^{-3}$, respectivamente para os solos NVef, LAw e G, a sorção do herbicida se reduziria a $50 \%$. Essa diferença observada quando se compara o efeito do nível de P na sorção do herbicida nos solos NVef e LAw contra o Gleissolo, pode ser explicada pelo teor de óxidos, principalmente de $\mathrm{Fe}$ e Al, presente nos dois primeiros solos (Tabela 2). Isto sugere, mais uma vez, a importância dos sítios de ligação covalente na sorção do glifosato, e ainda, a existência de outros mecanismos de ligação, principalmente no caso do Gleissolo. 

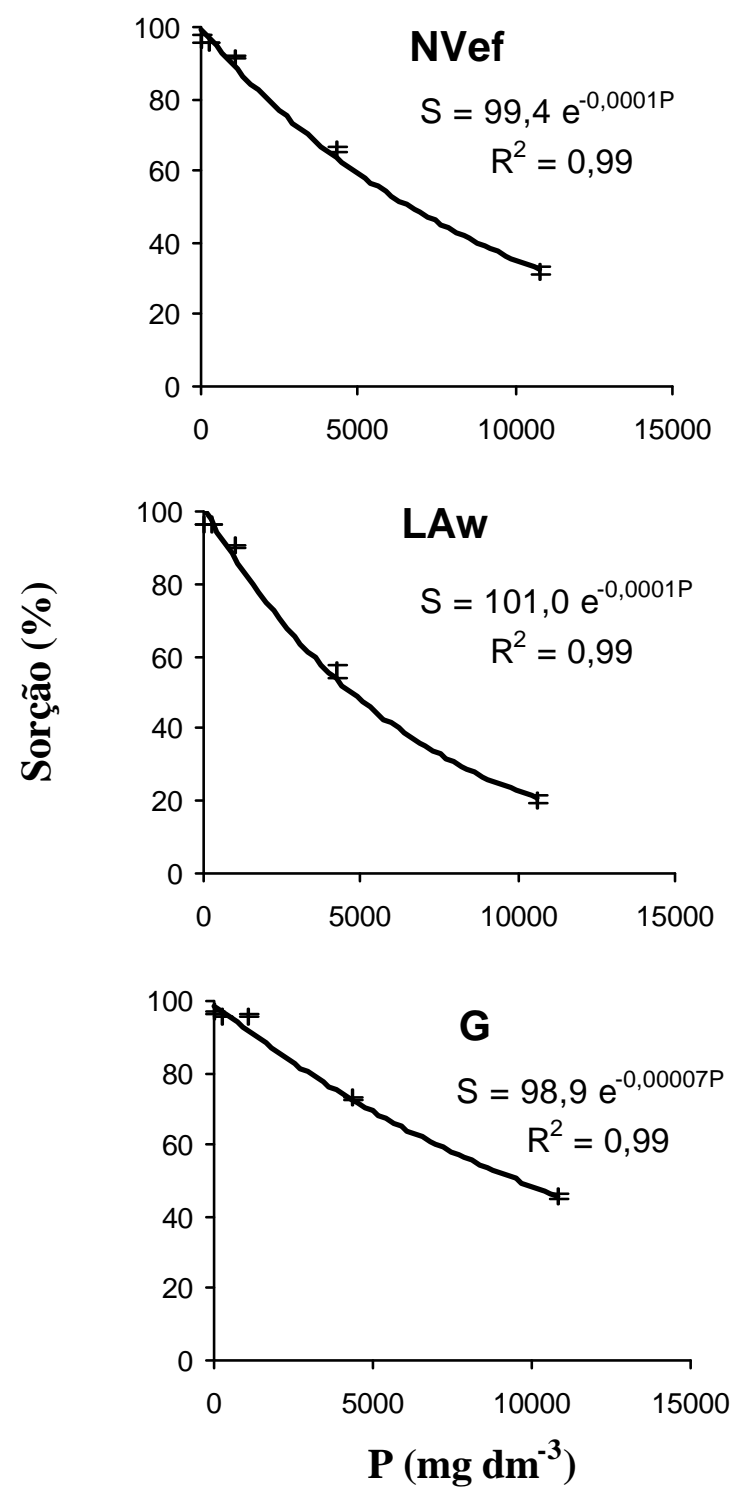

Figura 2. Relação entre a sorção do glifosato e níveis de $\mathrm{P}$ nos solos: Nitossolo Vermelho Eutroférrico (NVef), Latossolo Amarelo Acrico (LAw) e Gleissolo (G). Barras verticais correspondem ao desvio padrão da média.

Prata et al. (2000b), estudando o efeito da matéria orgânica na sorção do glifosato nestes mesmos solos, também sugeriram a ligação covalente entre o herbicida e os metais dos óxidos do solo como sendo o principal mecanismo de ligação para o 
glifosato. No entanto, mesmo desempenhando papel secundário, a matéria orgânica também é muito importante na retenção do glifosato, principalmente para solos pobres em óxidos, como o Gleissolo (Figuras 2 e 3). Nesse solo, é notório o menor efeito dos níveis de $\mathrm{P}$ na redução da sorção do glifosato quando comparado aos outros dois solos. Entretanto, a sorção inicial (nas testemunhas) ainda é muito elevada, sugerindo que outro, ou outros mecanismo de ligação também estejam ocorrendo nesse caso.

Piccolo et al. (1996) estudaram a sorção do glifosato em substâncias húmicas e verificaram valores de $K_{f}$ muito inferiores aos obtidos nesse trabalho para a dose inicial de $\mathrm{P}$ (Figura 3), embora ainda altos. Eles os atribuíram às ligações de hidrogênio entre a molécula e as substâncias húmicas e ainda observaram que, em moléculas húmicas de maior massa molecular e com cadeias carbônicas mais alifáticas, os valores dos coeficientes de sorção foram maiores. De acordo com os autores, o fato da molécula do glifosato possuir grupos que podem servir como doadores e receptores de prótons e as substâncias húmicas também possuírem grupos funcionais contendo oxigênio, por si só, sugere as ligações de hidrogênio como um possível mecanismo de ligação.

Esse comportamento pode ser considerado específico para o glifosato, pois essa é uma molécula orgânica com alta solubilidade em água $\left(S_{w}=11,6 \mathrm{~g} \mathrm{~L}^{-1}\right)$, sendo praticamente insolúvel em solventes orgânicos. Trata-se, portanto, de uma molécula com baixa hidrofobicidade $\left(\log \mathrm{K}_{\mathrm{ow}}=-4,1\right)$ que, ao contrário do esperado, apresenta elevada sorção.

Os valores das constantes de Freundlich também mostram que as reduções significativas $\left\{\left(\mathrm{K}_{\mathrm{f}}<50\left[\left(\mathrm{mg} \mathrm{g}^{-1}\right)\left(\mathrm{mL} \mathrm{mg}^{-1}\right)^{\mathrm{N}}\right]\right\}\right.$ vem ocorrer à partir dos níveis de $\mathrm{P}$ superiores a $1.000 \mathrm{mg} \mathrm{dm}^{-3}$ (Figura 3).

Jonge et al. (2001) estudaram a adsorção competitiva de $\mathrm{P}$ e glifosato em diferentes solos com elevados teores e óxidos e níveis de $\mathrm{P}$ (P-Olsen) variando de 6,19 a $87,39 \mathrm{mg} \mathrm{kg}^{-1}$. Eles observaram a redução dos valores de $K_{f}$ do glifosato nos tratamentos que continham maiores níveis de P. Todavia, a redução mais pronunciada de $K_{f}$ foi de 214,7 para 106,0 $\left\{\left[\left(\mathrm{mg} \mathrm{g}^{-1}\right)\left(\mathrm{mL} \mathrm{mg}^{-1}\right)^{\mathrm{N}}\right]\right\}$, o que, do ponto de vista de concentração sorvida, é uma redução quase que desconsiderável. Entretanto, embora os autores não tenham se baseado na relação entre $K_{d}$ e energia livre de Gibbs, proposta por Jung-Ho \& 
Feagley (1998), eles sugeriram que a redução nos valores de $K_{f}$, em decorrência da competição com os fosfatos inorgânicos pelos sítios de sorção, estaria contribuindo que o glifosato fosse sorvido via ligações de menor energia.
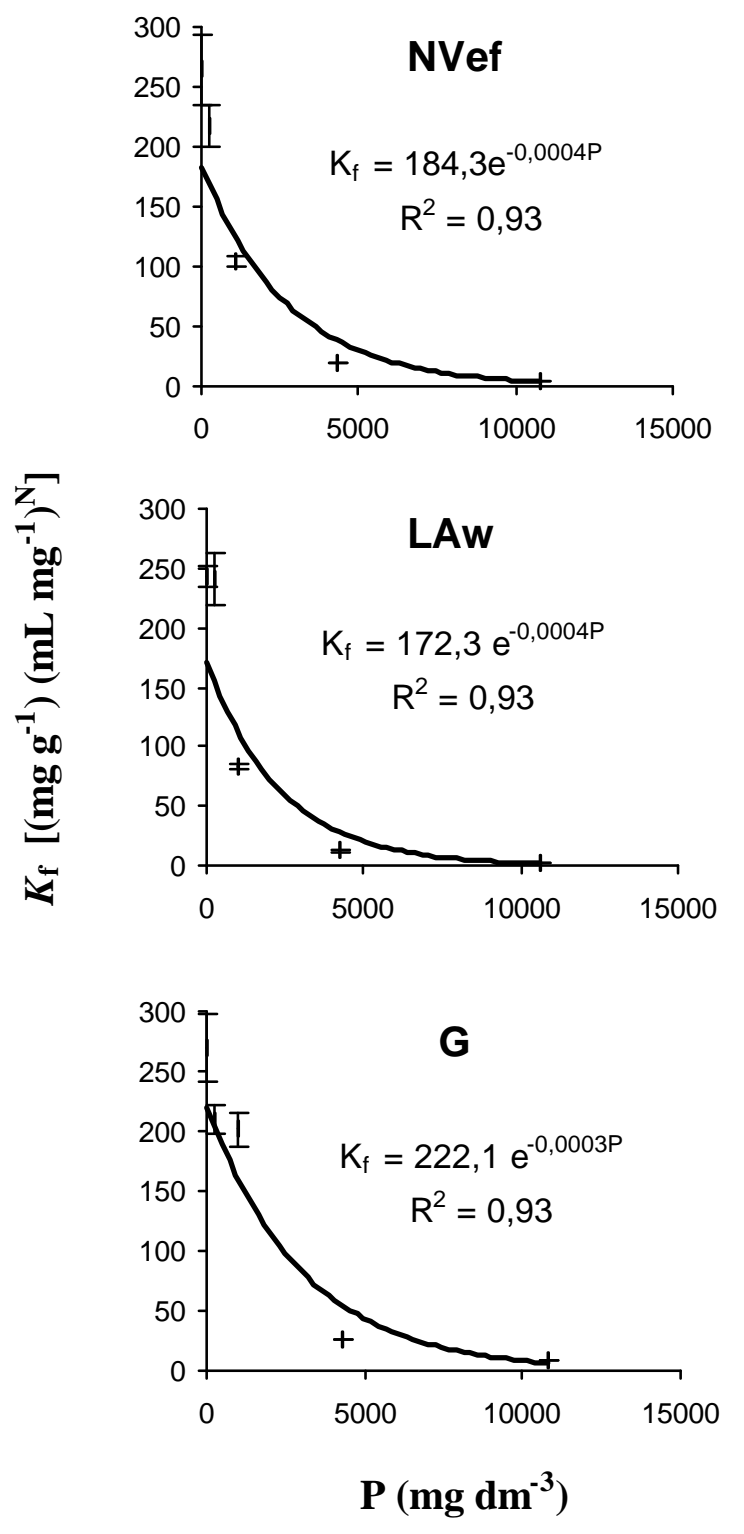

Figura 3. Relação entre coeficiente de Freundlich $\left(K_{f}\right)$ para o glifosato e níveis de P nos solos: Nitossolo Vermelho Eutroférrico (NVef), Latossolo Amarelo Acrico (LAw) e Gleissolo (G). Barras verticais correspondem ao desvio padrão da média. 
$\mathrm{O}$ fato das doses aplicadas de $\mathrm{KH}_{2} \mathrm{PO}_{4}$ terem elevado os valores de condutividade elétrica e $\mathrm{pH}$ dos solos (Tabela 4), não vem a ser um fator relevante na alteração da sorção do glifosato nestes solos estudados. Assim seria no caso de solos pouco intemperizados, com predominância de minerais de argila 2:1 e, especialmente, com valores de pH muito baixos, onde a ligação eletrostática passaria a desempenhar papel importante na sorção desse herbicida (McConnell \& Hossner, 1986). Em função de seu caráter zwiteriônico, em valores de $\mathrm{pH}$ inferiores a 2 o glifosato passa a ter carga líquida positiva (Figura 1), surgindo, para estes casos especiais, a importância das atrações eletrostáticas (Maqueda et al., 1998).

A extração total do glifosato (dessorções + extração) aumentou com a elevação dos níveis de $\mathrm{P}$ no solo (Figura 4), podendo ser praticamente desconsiderada para os níveis convencionais de $\mathrm{P}$ nos solos agricultáveis. Mesmo para os tratamentos com os maiores conteúdos de $\mathrm{P}$, a extração total foi baixa, em torno de $10 \%$ do total sorvido para os solos LAw e NVef (Figura 4). Não foi observada extração no Gleissolo.

As dessorções com $\mathrm{CaCh}$, assim como a extração total, aumentaram proporcionalmente com os níveis de $\mathrm{P}$ no solo (Figura 4), sendo mais importante que a extração com solução extratora "Mehlich 3" nos tratamentos com os maiores conteúdos de fósforo, o que provavelmente esteja relacionado diretamente com o aumento da força iônica nesse tratamento. Miles \& Moye (1988) também observaram que a dessorção do glifosato aumentou com o aumento da força iônica e do $\mathrm{pH}$, embora ainda fosse relativamente baixa, como no caso aqui estudado. Entretanto, esses resultados devem ser observados cautelosamente, pois a elevação da condutividade elétrica e do $\mathrm{pH}$ com as maiores doses de $\mathrm{P}$ podem ter favorecido a dispersão de argila nos solos NVef e LAw, que são solos com cargas variáveis. Considerando que foi determinada a radioatividade, a qual foi convertida para concentração de glifosato, isso implicaria na determinação de glifosato sorvido à micropartículas suspensas na solução de equilíbrio, o que poderia estar sendo contabilizado como glifosato dessorvido. 


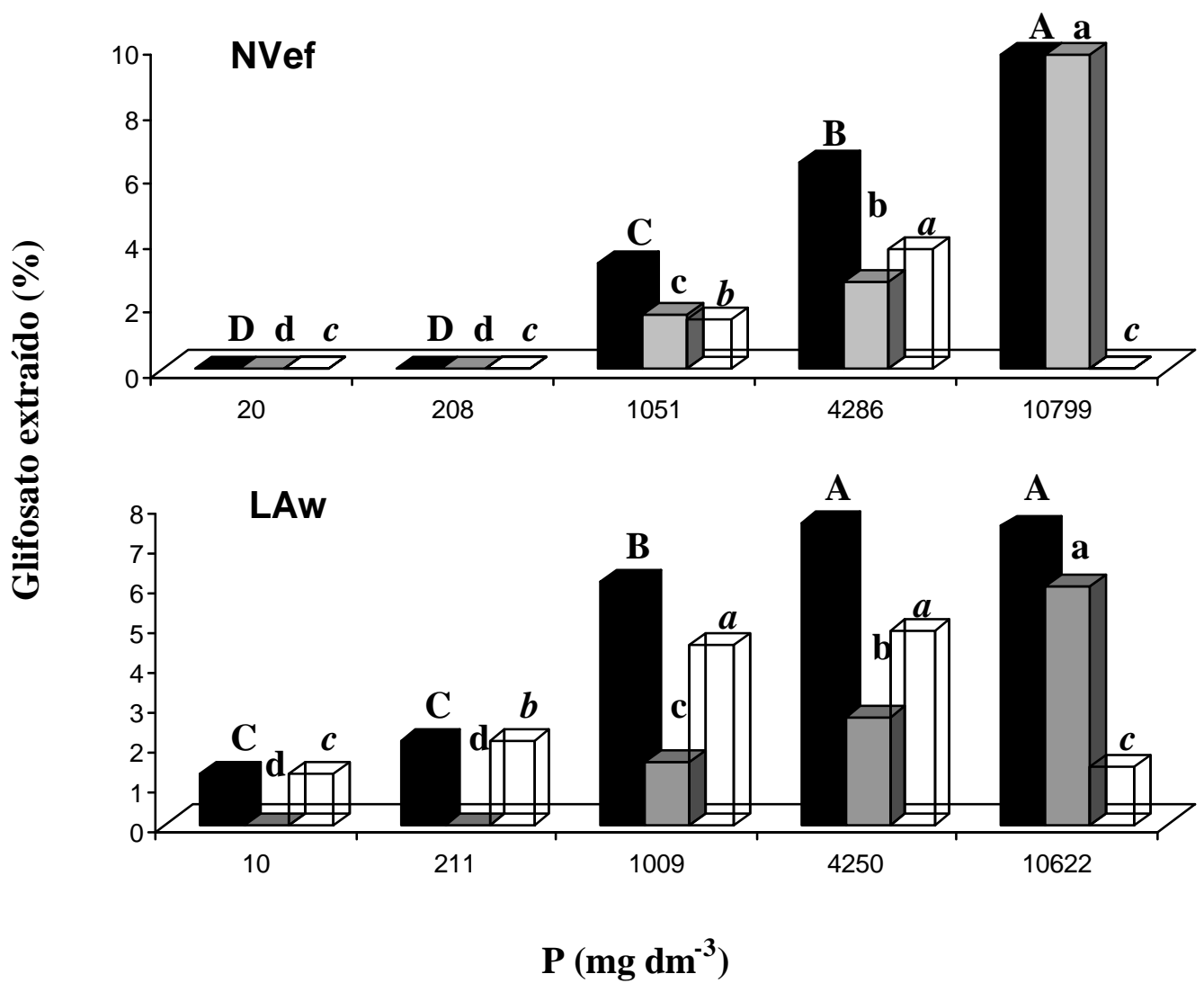

Extração total (dessorções + extração)

Dessorções

Extração

Figura 4. Extração total (4 dessorções + extração), dessorção e extração de glifosato dos solos Nitossolo Vermelho Eutroférrico (NVef) e Latossolo Amarelo Ácrico (LAw) com níveis crescentes de fósforo. Letras iguais significa não haver diferença estatística entre as médias pelo teste de Tukey $(\mathrm{p}<0,05)$.

Esse aspecto é muito importante, pois está diretamente relacionado com a movimentação de moléculas no solo, mesmo em sua forma de resíduo-ligado. A lixiviação de glifosato num solo dinamarquês foi observada por Jonge et al. (2000) em estudo de colunas indeformadas de solo. Nesse estudo, o valor de $K_{f}$ obtido foi elevado $\left\{59\left[\left(\mathrm{mg} \mathrm{g}^{-1}\right)\left(\mathrm{mL} \mathrm{mg}^{-1}\right)^{\mathrm{N}}\right]\right\}$ e a radioatividade na solução percolada, transformada em 
concentração de glifosato, variou proporcionalmente com a turbidez da solução, indicando a lixiviação de glifosato na forma de resíduo-ligado. Esses resultados de Jonge et al. (2000) também sugerem o efeito da dispersão de argila.

A extração do glifosato não é observada na maioria dos casos na literatura, e quando observada tem sido muito baixa (Miles \& Moye, 1988; Prata et al., 2000). Isto indica que o principal destino dessa molécula no solo é a formação de resíduo-ligado, que é uma das principais formas de dissipação de pesticidas no ambiente. No entanto, a identidade e biodisponibilidade dessa forma do pesticida ainda não foram esclarecidas.

\subsection{Conclusões}

O glifosato compete com o fósforo pelos sítios de sorção no solo, mas essa competição somente passa a ser importante quando os níveis de P no solo atingem valores muito elevados, os quais não são atingidos em condições de campo.

O glifosato é pouco extraído do solo e quase que a totalidade aplicada permanece no solo como resíduo-ligado. 


\section{COMPORTAMENTO DO GLIFOSATO EM LATOSSOLO VERMELHO SOB PLANTIO DIRETO E CONVENCIONAL}

\section{Resumo}

Este trabalho teve por objetivo estudar o comportamento do herbicida glifosato num Latossolo Vermelho argiloso, da região de Ponta Grossa, PR, sob 23 anos de plantio direto e convencional. Para tal, foram conduzidos 4 experimentos, nos quais foram verificados a mineralização e a formação de resíduo-ligado, a cinética de sorção e dessorção, a sorção/dessorção e a fitodisponibilidade no solo do glifosato para Panicum maximum var. mombaça. $\mathrm{O}$ ensaio de mineralização foi conduzido em delineamento inteiramente casualizado arranjado em fatorial $(2 \times 2)$, com 5 repetições, sendo os fatores os dois sistemas de cultivo e a posição de marcação radioativa do ${ }^{14} \mathrm{C}$-glifosato $\left({ }^{14} \mathrm{C}\right.$ fosfonometil e ${ }^{14} \mathrm{C} 2$-glicina). Foram realizadas avaliações do desprendimento de ${ }^{14} \mathrm{CO}_{2}$ semanalmente, até 63 dias. A cinética de sorção do glifosato foi conduzida seguindo o método "batch", para os dois sistemas de cultivo, utilizando-se a relação solo: solução de 1: 5 , e concentração de glifosato de $0,84 \mathrm{mg} \mathrm{L}^{-1}$. As determinações de radioatividade na solução de equilíbrio foram feitas nos períodos de $0,10,30,60,120,240$ e 360 minutos após a aplicação do herbicida. Os tempos utilizados na cinética de dessorção foram 0,1 , 4, 12, 24, 36, 48, 72 e 96 horas. O procedimento utilizado no ensaio de sorção/dessorção foi semelhante ao do estudo de cinética. No entanto, foram utilizadas cinco concentrações do herbicida: 0,$42 ; 0,84 ; 1,68 ; 3,36$ e $6,72 \mathrm{mg} \mathrm{L}^{-1}$, para a construção das isotermas. Ao final deste ensaio, foram realizadas 4 tentativas de dessorção somente na concentração de $0,84 \mathrm{mg} \mathrm{L}^{-1}$. Por fim, o ensaio de fitodisponibilidade foi conduzido em delineamento inteiramente casualizado, arranjado em fatorial 2 (sistemas de cultivo) x 5 (concentrações de glifosato aplicados ao solo: $0,4,2 ; 8,4 ; 42,0$ e 210,0 $\mu \mathrm{g} \mathrm{g}^{-1}$ de solo), 
sendo feitas avaliações dos sintomas visuais de fitotoxidez no capim mombaça em diferentes períodos de tempo. Para ambos os sistemas de cultivo, o glifosato apresentou elevados coeficientes de sorção, o que impediu sua dessorção e dificultou sua mineralização na solução do solo, pois a molécula permaneceu como resíduo-ligado. A cinética de sorção do glifosato é instantânea, sendo mínima a concentração sorvida na fase lenta. O glifosato, na forma de resíduo-ligado no solo, não constitui problemas para o Panicum maximum, seja sob plantio direto ou convencional. A mineralização do glifosato é mais rápida no plantio direto e o principal metabólito do glifosato é o ácido amino-metilfosfônico.

\section{GLYPHOSATE BEHAVIOR IN RHODIC OXISOL FROM NO-TILL AND CONVENTIONAL AGRICULTURAL SYSTEMS}

\section{Summary}

The behavior of glyphosate in a Rhodic Oxisol, collected from both no-till (PD) and conventional (PC) management soil systems at Ponta Grossa, Paraná State (Brazil) was evaluated. Both agricultural systems had been in production for 23 years. Glyphosate mineralization, soil-bound forms, sorption and desorption kinetics, sorption/desorption batch experiments, and soil glyphosate phythoavailability (to Panicum maximum) were determined. The mineralization experiment was a completely randomized design, in a $2 \times 2$ factorial (two management systems and two ${ }^{14} \mathrm{C}$ radiolabelled positions in the glyphosate), with five replicates. ${ }^{14} \mathrm{CO}_{2}$ evolution was measured at intervals of 7 days, during 63 days. Glyphosate sorption kinetics was determined for two management systems, using a soil-to-solvent ratio of $1 / 5$, and a

glyphosate concentration of $0.84 \mathrm{mg} \mathrm{L}^{-1}$. Equilibrium solution radioactivity was determined at $0,10,30,60,120,240$ and $360 \mathrm{~min}$. after herbicide application. Sorption/desorption batch experiments were carried out using five glyphosate concentrations: $0.42,0.84,1.68,3.36$, and $6.72 \mathrm{mg} \mathrm{L}^{-1}$. Glyphosate phytoavailability was 
analyzed in completely randomized design, with a 2x5 factorial setup with two field systems and five glyphosate concentrations applied to soil $(0,4.2,8.4,42.0$ and $210.0 \mu \mathrm{g}$ $\left.\mathrm{g}^{-1}\right)$. Phytotoxicity symptoms in P. maximum were evaluated at different times. The soil under both management systems showed high glyphosate sorption. Glyphosate sorption was practically instantaneous, with more than $90 \%$ sorbed until 10 minutes. Glyphosate bound-residues were not phytotoxic to $P$. maximum growth in either no-till or conventional systems. Glyphosate mineralization was faster in no-till than in conventional till. The main glyphosate metabolite was aminomethylphosphonic acid.

\subsection{Introdução}

A expansão das áreas de cultivo sob o sistema de plantio direto em diversas regiões do território brasileiro tem sido notável nos últimos anos. Estima-se que, atualmente, ao redor de 13,5 milhões de hectares vem sendo cultivados com este sistema no país (Derpsch, 2002), atingindo quase que 35\% da área com produção de grãos.

O sistema de plantio direto consiste numa prática de manejo agrícola baseada na manutenção dos restos culturais na superfície do solo e rotação de culturas. Com isto, ao invés de existir a camada arável, passa a existir uma camada superficial rica em matéria orgânica. Algum tempo após a adoção deste sistema, alguns atributos do solo são alterados, como a permeabilidade, distribuição dos nutrientes no perfil, retenção de água, conteúdo e qualidade da matéria orgânica entre outros (Rocha, 1999).

Nesse sistema de manejo, o uso dos implementos no controle das plantas daninhas antes do plantio, como é realizado no sistema convencional, é substituído pelo uso de herbicidas não seletivos, destacando-se moléculas como o paraquat, sulfosato e, principalmente, o glifosato.

Há mais de duas décadas o glifosato tem sido utilizado no Brasil, tendo seu uso ampliado expressivamente nos últimos anos em função, principalmente, da expansão do sistema de plantio direto no país.

Este herbicida é aplicado em pós-emergência e apresenta translocação apossimplástica. Ele atua na inibição da enzima 5-enolpiruvishiquimato-3-fosfato 
sintetase (EPSPS), interferindo na biossíntese de aminoácidos (Roberts et al., 1998). Na maior parte dos casos, o glifosato não é metabolizado pelas plantas, razão pela qual não apresenta seletividade. Somente variedades geneticamente modificadas para tal são resistentes a esse herbicida. Assim sendo, praticamente toda a concentração do ingrediente ativo aplicado chega ao solo na sua forma original.

O comportamento do glifosato no solo tem sido verificado para diferentes situações (Glass, 1987; Piccolo et al., 1994; Piccolo et al., 1996; Maqueda et al., 1998; Jonge et al., 2000; Jonge et al., 2001). No entanto, poucos são os estudos relacionados a solos de regiões sob clima tropical, destacando os trabalhos de Cheah et al. (1997) e Cheah et al. (1998), para solos africanos, e Prata et al. (2000) para solos brasileiros.

Embora o glifosato apresente elevada solubilidade em água $\left(S_{\mathrm{w}}=11,6 \mathrm{~g} \mathrm{~L}^{-1}\right)$ e baixa hidrofobicidade $\left(\log \mathrm{K}_{\mathrm{ow}}=-4,1\right)$, sua sorção é extremamente elevada na maioria das situações, chegando a apresentar valores de coeficiente de sorção linear da ordem de $1.188 \mathrm{~L} \mathrm{~kg}^{-1}$, para solos orgânicos (Cheah et al., 1997). Todavia, a sorção do glifosato parece estar mais relaciona à capacidade dos óxidos metálicos do solo em adsorver fosfato inorgânico (Hance, 1976, Glass, 1987; Gerritse et al., 1996; Jonge et al, 2001), o que sugere a formação de complexos de esfera interna entre essa molécula e os metais (Piccolo et al., 1994; Cheah et al., 1997; Jonge et al., 2001). Entretanto, alguns autores têm sugerido também a importância da matéria orgânica na sorção desta molécula (Piccolo et al., 1996; Prata et al., 2000). Piccolo et al. (1996), estudando mecanismos de ligação, verificou que, no caso das substâncias húmicas, o principal mecanismo de ligação do glifosato refere-se às pontes de hidrogênio.

Prata et al. (2000), mostraram que a matéria orgânica do solo desempenha papel secundário na sorção do glifosato. Entretanto, em solos com baixos teores de óxidos, esta vem a ser de fundamental importância na retenção deste herbicida, pois o confere elevada taxa de sorção. Em função disto, a persistência do glifosato em sua forma original e sua disponibilidade na solução do solo têm sido baixas, com valores médios de meia-vida de 38 dias (Rueppel et al., 1977). Por outro lado, a meia-vida de mineralização do glifosato pode atingir valores da ordem de até 22,7 anos (Nomura \& Hilton, 1977). 
A maior parte dos processos que governam o destino dos herbicidas no solo pode, teoricamente, sofrer interferência das alterações provocadas pela adoção do sistema de plantio direto num determinado ambiente, como principalmente as alterações na matéria orgânica e na microbiologia do solo. Com isso, esse trabalho tem o objetivo de estudar o comportamento do glifosato em condições específicas de um Latossolo Vermelho, sob longo período de adoção dos sistemas de plantio direto e convencional, verificando assim a mineralização e a formação de resíduo-ligado, a cinética de sorção e dessorção, a sorção/dessorção e a fitodisponibilidade no solo do glifosato, utilizando o capim mombaça (Panicum maximum) como planta teste.

\subsection{Material e Métodos}

\section{Solos}

Para todos os experimentos, foram utilizadas amostras de um Latossolo Vermelho Distroférrico argiloso, da região de Ponta Grossa, PR, mantido há 23 anos sob sistema de plantio direto e convencional (áreas adjacentes de mesma topografia).

As amostras de solo foram coletadas entre $0-5 \mathrm{~cm}$ de profundidade, sendo posteriormente secas ao ar e passadas em peneira com malha de $2 \mathrm{~mm}$. Durante a coleta e o início dos experimentos, o solo foi armazenado por 22 dias em geladeira. Os resultados das análises químicas e dos atributos granulométricos e mineralógicos estão descritos nas Tabelas 5 e 6, respectivamente. As análises químicas e granulométricas foram feitas de acordo com Raij \& Quaggio (1983) e Camargo et al. (1986), respectivamente. $\mathrm{O} F$ Fe total $\left(\mathrm{Fe}_{2} \mathrm{O}_{3}\right)$ e o $\mathrm{Al}$ total $\left(\mathrm{Al}_{2} \mathrm{O}_{3}\right)$ foram extraídos com $\mathrm{H}_{2} \mathrm{SO}_{4} 18$ mol L $\mathrm{L}^{-1}$ (Jackson, 1969). Os minerais de argila predominantes foram identificados por difração de raios-X (Jackson, 1969). 
Tabela 5 - Características químicas de um Latossolo Vermelho Distroférrico, mantido há 23 anos sob plantio direto (PD) ou plantio convencional (PC)

\begin{tabular}{|c|c|c|c|c|c|c|c|c|c|}
\hline $\begin{array}{l}\text { Sistema } \\
\text { Manejo }\end{array}$ & $\mathrm{pH}_{\mathrm{CaCl} 2}$ & C org & $P$ & $\mathrm{~K}$ & $\mathrm{Ca}$ & $\mathrm{Mg}$ & $\mathrm{H}+\mathrm{Al}$ & $\mathrm{Al}$ & CTC \\
\hline & & $\mathrm{g} \mathrm{kg}^{-1}$ & $\mathrm{mg} \mathrm{kg}^{-1}$ & $\ldots \ldots$ & $\ldots \ldots . . .$. &.. $\mathrm{mm}$ & $\mathrm{ol}_{\mathrm{c}} \mathrm{dm}^{-3}$ & & ........ \\
\hline PD & 5,2 & 32,0 & 89 & 3,8 & 71 & 25 & 42 & 0 & 141,8 \\
\hline $\mathrm{PC}$ & 5,0 & 25,0 & 59 & 5,2 & 51 & 20 & 47 & 0 & 123,2 \\
\hline
\end{tabular}

Tabela 6. Atributos granulométricos e mineralógicos de um Latossolo Vermelho Distroférrico, mantido há 23 anos sob plantio direto (PD) ou plantio convencional (PC)

\begin{tabular}{ccccccc}
\hline Sistema Manejo & Areia & Silte & Argila & $\mathrm{Al}_{2} \mathrm{O}_{3}$ & $\mathrm{Fe}_{2} \mathrm{O}_{3}$ & Mineralogia de argila \\
\hline & $\ldots \ldots \ldots \ldots \ldots \ldots \ldots \ldots \ldots . . . \mathrm{g} \mathrm{kg}^{-1}$ & $\ldots \ldots \ldots \ldots \ldots \ldots \ldots \ldots \ldots \ldots \ldots \ldots \ldots \ldots \ldots \ldots \ldots \ldots \ldots \ldots$ & \\
PD & 460 & 70 & 470 & 158,1 & 64,7 & $\mathrm{Ct}^{1 /} ; \mathrm{Gb}^{2 /} ; \mathrm{VHI}^{3 /}$ \\
PC & 380 & 60 & 560 & 189,7 & 87,4 & $\mathrm{Ct} ; \mathrm{Gb} ; \mathrm{VHI}$ \\
\hline
\end{tabular}

${ }^{1}$ Caulinita. ${ }^{2 /}$ Gibsita. ${ }^{3 /}$ Vermiculita com hidroxila nas intercamadas

\section{Mineralização e atividade microbiana}

$\mathrm{O}$ ensaio de mineralização do glifosato foi conduzido em delineamento inteiramente casualizado, arranjado em fatorial (2x2), com 5 repetições. Os fatores foram os dois sistemas de cultivo e a marcação radioativa do ${ }^{14} \mathrm{C}$-glifosato $\left({ }^{14} \mathrm{C}\right.$ fosfonometil e ${ }^{14} \mathrm{C} 2$-glicina) (Figura 5).

A concentração do glifosato (produto técnico + radioativo) utilizada foi de $4,2 \mu \mathrm{g}$ $\mathrm{g}^{-1}$ de solo (equivalente a $2,52 \mathrm{~kg} \mathrm{ha}^{-1}$ de ingrediente ativo, considerando $5 \mathrm{~cm}$ de profundidade e $\mathrm{d}=1,2 \mathrm{~g} \mathrm{~cm}^{-3}$ ), com radioatividade correspondente a 25,4 e $17,2 \mathrm{kBq}$ $100 \mathrm{~g}^{-1}$, para o glifosato ${ }^{14} \mathrm{C}$-fosfonometil e ${ }^{14} \mathrm{C} 2$-glicina, respectivamente. A atividade específica do glifosato $\left({ }^{14} \mathrm{C}\right.$-fosfonometil) foi de $5,155 \mathrm{MBq} \mathrm{mg}^{-1}$ e a do glifosato $\left({ }^{14} \mathrm{C} 2\right.$ glicina) de 7,397 $\mathrm{MBq} \mathrm{mg}^{-1}$, sendo que a pureza analítica de ambos foi superior a $97 \%$. 

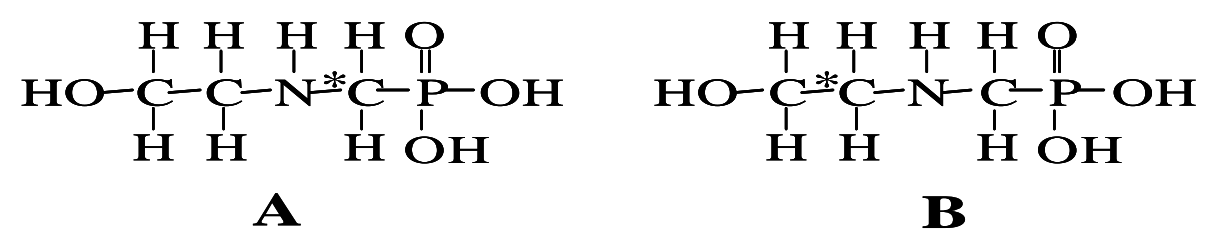

Figura 5. ${ }^{14} \mathrm{C}$-Glifosato [n-(fosfonometil)glicina]. * Posição de radiomarcação $\left({ }^{14} \mathrm{C}\right)$ : $\mathrm{A}=$ Glifosato $\left({ }^{14} \mathrm{C}\right.$-fosnonometil $) ; \mathrm{B}=$ glifosato $\left({ }^{14} \mathrm{C} 2\right.$-glicina $)$

O experimento foi realizado em frascos de boca larga $(500 \mathrm{~mL})$, hermeticamente fechados, utilizando-se uma massa de solo de $100 \mathrm{~g}$ (base seca) por frasco. Para a aplicação do herbicida, elevou-se a umidade das amostras de solo a $60 \%$ da capacidade de campo e aguardou-se 4 dias. Os isótopos do glifosato foram aplicados diretamente sobre a superfície das amostras $\left(400 \mu \mathrm{L} 100 \mathrm{~g}^{-1}\right)$ e imediatamente foi feita a homogeneização do solo.

Para coleta do ${ }^{14} \mathrm{CO}_{2}$ desprendido do herbicida, acondicionou-se um frasco de cintilação, com $10 \mathrm{~mL}$ de solução de $\mathrm{NaOH} 0,2 \mathrm{~mol} \mathrm{~L}^{-1}$, dentro de cada frasco contendo a massa de terra. A base metodológica consistiu na detecção da radioatividade presente no $\mathrm{NaH}^{14} \mathrm{CO}_{3}$, formado da reação entre o ${ }^{14} \mathrm{CO}_{2}$ desprendido do herbicida e o $\mathrm{NaOH}$. A radioatividade foi detectada por espectrometria de cintilação líquida (ECL), em alíquotas de $1 \mathrm{~mL}$ da solução contida nos frascos de cintilação. $\mathrm{O}$ ensaio foi conduzido por 63 dias, no escuro, a $25 \pm 2{ }^{\circ} \mathrm{C}$, mantendo-se a umidade do solo a $60 \%$ da capacidade de campo. As avaliações foram feitas nos dias 7, 14, 21, 28, 35, 42, 49, 56 e 63 após a aplicação do herbicida. Durante os períodos de avaliação, a massa de solo foi homogeneizada para evitar a anaerobiose do sistema.

No final do período de incubação, foram realizadas três tentativas de extração do herbicida por agitação, durante 2 horas, utilizando-se $\mathrm{CaCh}_{2} \quad 0,01 \mathrm{~mol} \mathrm{~L}^{-1}$ nas duas primeiras e solução extratora "Mehlich 3" (Mehlich, 1984) na última. A solução extratora "Mehlich 3" é utilizada para extração de P no solo e consiste numa mistura de $\mathrm{HCl} 0,1 \mathrm{~mol} \mathrm{~L}^{-1}$ e $\mathrm{NH}_{4} \mathrm{~F} 0,03 \mathrm{~mol} \mathrm{~L}^{-1}$. O íon $\mathrm{F}^{-}$presente no extrator atua na complexação do $\mathrm{Al}^{3+}$ e do $\mathrm{Ca}^{2+}$ na solução do solo, fazendo com que o $\mathrm{P}$ precipitado seja solubilizado 
e, assim, possa ser determinado. A solução "Mehlich 3" foi empregada no presente estudo por assumirmos que o grupamento metilfosfônico do glifosato pode apresentar comportamento no solo semelhante ao dos fosfatos inorgânicos.

Após as extrações, alíquotas de amostras de solo foram oxidadas em oxidador biológico e a radioatividade presente foi detectada por ECL, para o fechamento do balanço de radioatividade.

O modelo de cinética de degradação de primeira ordem (eq. 29 e 30, Sparks, 1989) foi empregado para modelar a radioatividade residente no solo, assim como as concentrações de ${ }^{14} \mathrm{CO}_{2}$ desprendidas do herbicida.

$$
C=C_{0} e^{-k_{1} t}
$$

Na equação (29), $C$ representa a concentração de glifosato remanescente no solo no tempo $t, C_{0}$ a concentração de glifosato remanescente no solo no tempo zero, $k_{1}$ a constante de velocidade de mineralização $\left(\operatorname{dia}^{-1}\right)$ e $t$ o tempo de incubação (dias).

Através linearização da eq. (29), utilizando-se os valores de $k_{1}$ e considerando o período de tempo em que $50 \%$ do reagente passa a produto na reação, foi possível calcular a meia-vida de mineralização $\left(t_{1 / 2} \min\right.$.) do glifosato:

$$
t_{1 / 2} \min .=\frac{\ln 2}{k_{1}}
$$

No caso específico do glifosato em solos oxídicos, onde grande parte da concentração aplicada apresenta sorção irreversível (formação de resíduo-ligado) (Prata et al., 2000b), considerando que as formas de resíduo-ligado são formas pouco degradadas por microrganismos (Steen et al., 1980) e ainda, que a degradação do glifosato ocorre principalmente via bactérias na solução do solo (Quinn et al., 1988; Krzysko-Lupicka \& Orlik, 1997), pode-se considerar que a constante $k_{2}$ (eq. 31) representa a constante de velocidade de dissipação. Neste caso, a equação (2) pode ser reescrita como:

$$
C_{1}=C_{0}\left(1-e^{-k_{2} t}\right)
$$

em que $C_{1}$ é a concentração de ${ }^{14} \mathrm{CO}_{2}$ desprendido. 
A meia-vida de dissipação, ou apenas meia-vida, simbolizada aqui por $t_{1 / 2}$ dis. para diferenciar-se da meia-vida de mineralização, refere-se ao tempo em que $50 \%$ da concentração total aplicada do herbicida não mais se encontra na forma original. No caso particular do glifosato, ela corresponde à somatória das concentrações degradada e sorvida irreversivelmente (fração resíduo-ligado). A $t_{1 / 2}$ dis. pode ser calculada utilizando-se a seguinte equação:

$$
t_{1 / 2} \text { dis. }=\frac{\ln 2}{k_{2}}
$$

Para a avaliação da atividade microbiana durante esse ensaio, foram conduzidas paralelamente duas parcelas adicionais para cada sistema de cultivo. A estas, foram aplicados somente o herbicida técnico, seguindo os mesmos moldes do experimento de mineralização. Em sub-amostras de terra desses frascos foi avaliada a atividade microbiana nos dias $0,15,30,45$ e 60 após a aplicação do glifosato, de acordo com o método da ${ }^{14} \mathrm{C}$-glicose (Freitas et al., 1979).

Análises de variância e teste de comparação de médias (Tukey, $\mathrm{p}<0,05$ ) foram realizados para os valores de desprendimento acumulado de ${ }^{14} \mathrm{CO}_{2}$ aos 28 e 63 dias, $t_{1 / 2} \min$. e $t_{1 / 2}$ dis.

\section{Cinética de sorção e dessorção}

A cinética de sorção do glifosato foi avaliada para os dois sistemas de cultivo (PD e PC). Para tanto, utilizoutse a relação solo: $\mathrm{CaCh}_{2} \quad 0,01 \mathrm{~mol} \mathrm{~L}^{-1}$ de 1: 5, procedendo-se as determinações de radioatividade na solução de equilíbrio nos períodos de $0,10,30,60,120,240$ e 360 minutos após a aplicação do herbicida. O ensaio foi conduzido em triplicata.

A concentração de glifosato aplicada foi de $0,84 \mathrm{mg} \mathrm{L}^{-1}$, com radioatividade de $0,233 \mathrm{kBq} \mathrm{mL}^{-1}$. O isótopo radioativo empregado nesse estudo, assim como no subsequente de sorção/dessorção, foi o mesmo glifosato $\left({ }^{14} \mathrm{C}\right.$-fosfonometil) utilizado no estudo de mineralização.

O procedimento desse ensaio (procedimento "batch") consistiu-se na agitação da suspensão solo: solvente em agitador horizontal a $120 \mathrm{rpm}$, durante os períodos de 
equilíbrio pré-estabelecidos, e posterior centrifugação a 3000 rpm durante 10 minutos. A radioatividade foi determinada em alíquota de $1 \mathrm{~mL}$ da solução de equilíbrio por ECL. As proporções sorvidas do herbicida foram calculadas por diferença entre o total aplicado e o determinado nas soluções de equilíbrio.

A cinética de dessorção foi realizada utilizando-se uma concentração inicial de glifosato de $0,84 \mathrm{mg} \mathrm{L}^{-1}$. Os períodos de equilíbrio adotados foram de $0,1,4,12,24,36$, 48, 72 e 96 horas, sendo o ensaio realizado em triplicata.

Aos dados de cinética de sorção foi ajustado o modelo de cinética de Elovich (Sparks, 1989):

$$
\frac{\partial S}{\partial t}=X e^{-Y S}
$$

em que, $S$ representa a concentração sorvida, $t$ o tempo de equilíbrio e $X$ e $Y$ são constantes da equação, específicas para o experimento.

A forma integrada desse modelo, a qual foi ajustada os dados desse trabalho, é descrita abaixo:

$$
S=(1 / Y) \ln (X Y)+(1 / Y) \ln t
$$

Os valores de $[(1 / Y) \ln (X Y)]$ e $(1 / Y)$ representam, respectivamente, a concentração total sorvida no tempo de equilíbrio inicial (fase rápida da cinética de sorção) e a taxa de variação da sorção em função do tempo para a fase lenta da cinética.

\section{Sorção/dessorção}

O procedimento do estudo de sorção/dessorção do glifosato foi semelhante ao utilizado na cinética. No entanto, foram utilizadas cinco concentrações do herbicida $\left(0,42 ; 0,84 ; 1,68 ; 3,36\right.$ e $\left.6,72 \mathrm{mg} \mathrm{L}^{-1}\right)$ para a construção das isotermas.

O ensaio foi conduzido com seis repetições e o tempo de agitação de equilíbrio adotado (em função das observações feitas no estudo de cinética) foi de 2 horas para a sorção e quatro horas para a dessorção, sendo a radioatividade determinada em ECL em alíquotas de 1,0 mL. A dessorção foi realizada somente na concentração de $0,84 \mathrm{mg} \mathrm{L}^{-1}$, sendo repetida por 4 vezes. 
Para o cálculo das constantes de Freundlich, foi utilizado o modelo matemático de Freundlich (eq. 28).

Com os valores dos coeficientes de sorção linear, $K_{d}$, $\left(=S / C_{e}\right.$, ou $=K_{f}$, quando $0,9<N<1,1)$ e o conteúdo de carbono dos solos, foi calculado o coeficiente de sorção linear normalizado para o conteúdo de carbono orgânico $\left(K_{\mathrm{oc}}\right)$ :

$$
K_{o c}=\frac{K_{d}}{\operatorname{Corg} .} 100
$$

A partir dos valores de $t_{1 / 2}$ dis. e $K_{\mathrm{oc}}$, calculou-se a estimativa do potencial de lixiviação do glifosato, através do índice GUS (Gustafson, 1989) (eq. 27).

Análises de variância e teste de comparação de médias (Tukey, p < 0,05) foram realizados para os valores de percentagem total sorvida, $K_{\mathrm{oc}}$ e $K_{f}$.

\section{Teste biológico}

O último ensaio foi um teste biológico, que foi fundamentado em diagnoses visuais dos sintomas de fitotoxidez de glifosato, aplicado ao solo, em plantas de capim mombaça (Panicum maximum). Este ensaio teve o objetivo de confirmar os resultados dos ensaios anteriores, agora envolvendo a planta. Para tal, foram utilizados vasos de plástico preenchidos com $400 \mathrm{~g}$ de solo seco, provenientes dos tratamentos PD e PC, respectivamente. $\mathrm{O}$ ensaio foi desenvolvido em delineamento inteiramente casualizado arranjado em fatorial $2 \times 5$, sendo o primeiro fator os sistemas de cultivo (PD e PC) e o segundo as doses de glifosato $\left(0,4,2 ; 8,4 ; 42,0\right.$ e $210,0 \mu \mathrm{g} \mathrm{g}^{-1}$ de solo, correspondentes a $0,1,2,10$ e 50 vezes a dose máxima recomendada, assumindo para base de cálculo $5 \mathrm{~cm}$ de profundidade e $d_{s}=1,2 \mathrm{~g} \mathrm{~cm}^{-3}$ ). $\mathrm{O}$ experimento foi desenvolvido em casa de vegetação, com cinco repetições.

Os solos foram umedecidos a $60 \%$ da capacidade de campo, sendo a aplicação do herbicida realizada em superfície, com posterior homogeneização. Imediatamente após a aplicação, foram semeadas 10 sementes de mombaça por vaso.

A avaliações dos sintomas foram realizadas por três avaliadores distintos, os quais atribuíram notas de acordo com os sintomas de fitotoxidez. Estas notas foram atribuídas através de comparação com as testemunhas, sendo que as médias dessas notas 
foram transformadas em percentagem de sintoma visual de fitotoxidez. As avaliações foram feitas 7, 14 e 20 dias após a germinação das plantas, numa primeira etapa. Após esse período, as plantas foram retiradas dos vasos e os solos permaneceram sem adição de água por quarenta dias. Sessenta e quatro dias após a aplicação do herbicida, com o solo já sem as plantas, elevourse novamente a capacidade de campo dos solos a $60 \%$ e nova semeadura foi procedida de forma semelhante à anterior, no entanto, sem aplicação do herbicida. Subseqüentemente, novas avaliações dos sintomas visuais de fitotoxidez foram procedidas aos 10 e 20 dias após a germinação da mombaça.

Foram realizadas análises de regressão entre os sintomas e as doses de glifosato apenas com as observações feitas aos 24 e 84 dias após a aplicação do herbicida.

\subsection{Resultados e Discussão}

\section{Mineralização e atividade microbiana}

Após 63 dias de incubação, o desprendimento de ${ }^{14} \mathrm{CO}_{2}$ do glifosato foi superior nos tratamentos sob plantio direto (PD) em relação aos sob plantio convencional (PC) (Tabela 7). Provavelmente, isso se deve a maior atividade microbiana no solo sob PD durante a condução do experimento (Figura 6). De fato, em estudos de laboratório a atividade microbiana tem sido superior nos tratamentos envolvendo PD em comparação ao PC (Rocha, 1999), o que pode estar relacionado aos maiores conteúdos de carbono e P no plantio direto (Tabela 5).

De acordo com a classificação do IBAMA para persistência de moléculas no solo (Brasil, 1988), baseada em resultados de desprendimento de ${ }^{14} \mathrm{CO}_{2}$ durante 28 dias, a persistência do glifosato nesse estudo foi alterada com o sistema de cultivo, tendo sido classificada como "média" no PC (3,8 e 6,0\%), chegando a valores superiores a $10 \%$ no PD, o que lhe configura persistência "reduzida" segundo esta classificação (Tabela 7). Todavia, a classificação para persistência de xenobióticos do IBAMA é muito limitada. Esta classificação é fundamentada em resultados de desprendimento de ${ }^{14} \mathrm{CO}_{2}$ acumulado durante 28 dias e leva em consideração apenas três tipos de solo, sendo que um deles (Gleissolo) é de uso agrícola extremamente limitado. 
A percentagem de mineralização do glifosato variou de acordo com posição de marcação da molécula (Tabela 7). Em ambos os sistemas de cultivo, a mineralização foi mais rápida quando a molécula apresentou radiomarcação no carbono dois $\left({ }^{14} \mathrm{C} 2\right)$ do grupo glicina. (Tabela 7). Isto indica a formação do metabólito ácido aminometilfosfônico (AMPA), que é o principal produto da transformação do glifosato no solo (Rueppel et al., 1977; Roy et al., 1989; Cheah et al., 1998). Esse metabóbito, entretanto, por ainda conter o grupo metilfosfônico, teoricamente pode apresentar valores de sorção comparáveis aos da molécula original, o que pode vir a restringir a mineralização comp leta do glifosato no solo.

Para estudos de mineralização, os resultados deste trabalho (Tabela 7) indicam que a melhor posição de marcação do ${ }^{14} \mathrm{C}$-glifosato deve ser o carbono do grupo fosfonometil. Sabendo-se que o AMPA é o principal metabólito do glifosato e que, assim como a molécula original, ele apresenta elevada taxa de sorção, quando a radiomarcação se dá no C2 do grupo glicina, pode-se induzir a erros significativos de interpretação dos resultados. Neste caso, embora os resultados de desprendimento de ${ }^{14} \mathrm{CO}_{2}$ possam indicar a mineralização completa, o que pode estar ocorrendo é a mineralização somente do grupamento glicina e a formação de AMPA. Por outro lado, em estudos de degradação, o fato do glifosato apresentar extração mínima no solo (Prata et al., 2000b; Tabela 7) faz com que sua metabolização somente seja verificada através da utilização da molécula radiomarcada nas duas posições.

Os valores de meia-vida de mineralização do glifosato $\left(t_{1 / 2} \mathrm{~min}\right.$.) variaram entre 252,6 e 782,1 dias, sendo mais elevados no PC e com a utilização da molécula radiomarcada no carbono do grupo fosfonometil (Tabela 7). Os valores de $t_{1 / 2} \mathrm{~min}$. observados na literatura para o glifosato variam de 19,2 dias, para solos arenosos (Cheah et al., 1998), a 22,7 anos, para solos vulcânicos com elevado grau de sorção (Nomura \& Hilton, 1977). Já os valores de meia-vida de dissipação ( $t_{1 / 2}$ dis.) variaram entre 14,5 e 25,8 dias, sendo também mais elevados no sistema de $\mathrm{PC}$, para a marcação ${ }^{14} \mathrm{C}$ fosfonometil (Tabela 7). 
Tabela 7. Desprendimento de ${ }^{14} \mathrm{CO}_{2}$, meia-vida de mineralização $\left(t_{1 / 2} \min\right.$. $)$ e de dissipação $\left(t_{1 / 2}\right.$ dis. $)$ e extração de ${ }^{14} \mathrm{C}$-glifosato, radiomarcado em posições diferentes da molécula, em Latossolo Vermelho Distroférrico mantido há 23 anos sob plantio direto (PD) ou convencional (PC)

\begin{tabular}{|c|c|c|c|c|c|c|c|}
\hline \multirow{2}{*}{$\begin{array}{l}\text { Sistema } \\
\text { Manejo }\end{array}$} & \multirow[t]{2}{*}{ Posição do ${ }^{14} \mathrm{C}$} & \multicolumn{2}{|c|}{${ }^{14} \mathrm{CO}_{2}$ desprendido } & \multirow[t]{2}{*}{$t_{1 / 2} \min }$. & \multirow[t]{2}{*}{$t_{1 / 2}$ dis. } & \multirow{2}{*}{$\begin{array}{c}\mathrm{R}^{2} \\
\left(t_{1 / 2} \text { dis }\right)\end{array}$} & \multirow{2}{*}{$\begin{array}{l}\text { Glifosato } \\
\text { Extraído }\end{array}$} \\
\hline & & 28 dias & 63 dias & & & & \\
\hline \multirow{3}{*}{ PD } & & .................. \% & …................... & ..................... dia & …................. & & $\%$ \\
\hline & C - fosfonometil & $7,5 \pm 0,5 b^{1 /}$ & $10,8 \pm 0,9 b$ & $440,0 \pm 39,3 \mathrm{c}$ & $19,3 \pm 2,2 b$ & $0,98 * *$ & 0,0 \\
\hline & C2 - glicina & $11,2 \pm 0,5 \mathrm{a}$ & $17,1 \pm 0,8 \mathrm{a}$ & $252,6 \pm 12,8 \mathrm{~d}$ & $14,5 \pm 0,8 \mathrm{c}$ & $0,99 * *$ & 0,0 \\
\hline \multirow[t]{2}{*}{$\mathrm{PC}$} & C - fosfonometil & $3,8 \pm 0,1 \mathrm{~d}$ & $5,6 \pm 0,2 \mathrm{~d}$ & $782,1 \pm 32,8$ a & $25,8 \pm 1,4 \mathrm{a}$ & $0,99 * *$ & 0,0 \\
\hline & $\mathrm{C} 2$ - glicina & $6,0 \pm 0,4 \mathrm{c}$ & $8,6 \pm 0,8 \mathrm{c}$ & $539,1 \pm 58,4 b$ & $18,4 \pm 2,2 b$ & $0,99 * *$ & 0,0 \\
\hline
\end{tabular}

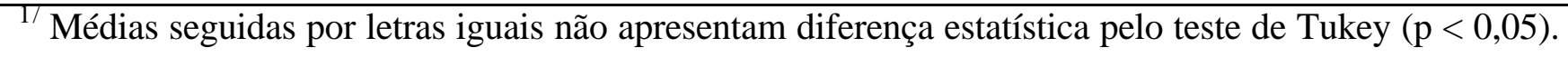




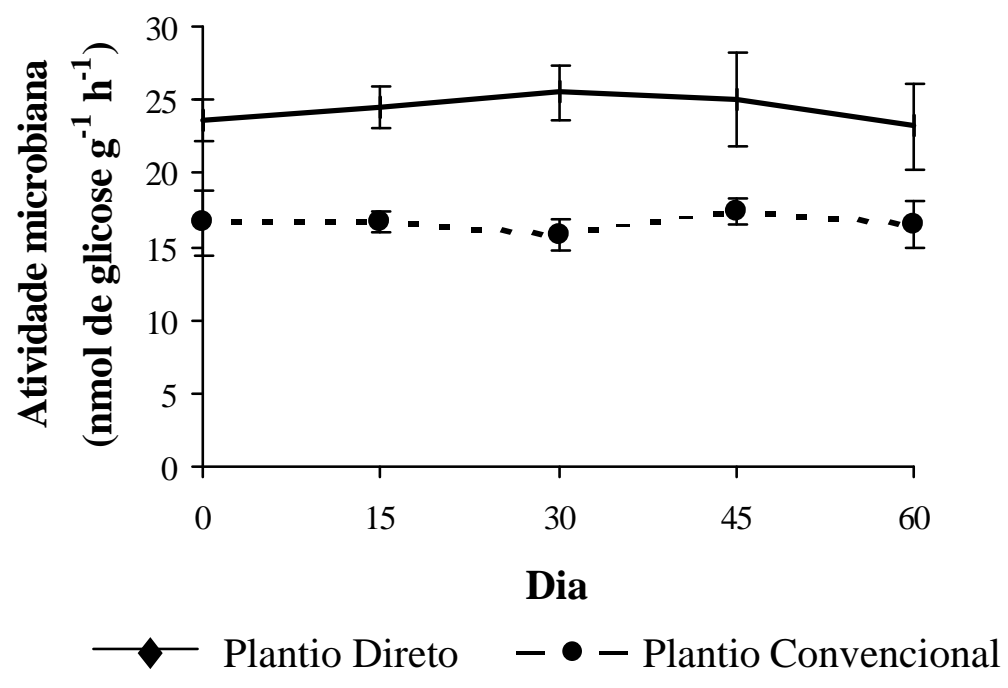

Figura 6. Atividade microbiana num Latossolo Vermelho Distroférrico mantido há 23 anos sob plantio direto ou convencional. As Barras verticais correspondem ao desvio padrão da média

O modelo proposto para a estimativa da $t_{1 / 2}$ dis. ajustou-se com sucesso aos dados de desprendimento de ${ }^{14} \mathrm{CO}_{2}$ (Tabela 7). Para tanto, assumiu-se que a molécula é predominantemente transformada quando na solução do solo, sendo que fração remanescente (não mineralizada) representa a fase resíduo-ligado. Esta inferência pode ser pode ser fundamentada para o comportamento do glifosato em solos oxídicos, onde o principal mecanismo de retenção refere-se à formação de complexos de esfera interna com os metais desses óxidos, com dessorção praticamente inexistente (Piccolo et al., 1994; Cheah et al., 1997; Jonge et al., 2001). Aliado a isso, ainda existe o fato da degradação do glifosato ser principalmente via bactérias (Quinn et al., 1988; KrzyskoLupicka \& Orlik, 1997), sugerindo a solução do solo como região primordial para degradação dessa molécula. Dessa forma, a $t_{1 / 2}$ dis. proposta nesse trabalho representa o período de tempo (dias) em que 50\% do glifosato sorvido e passível de retornar a solução do solo, ou seja, do glifosato sorvido em sítios de sorção em equilíbrio com a solução (não adsorvido covalentemente) é mineralizado. Os valores de $t_{1 / 2}$ dis. aqui 
calculados (Tabela 7) estão de acordo com os valores de $t_{1 / 2}$ dis. obtidos por outros autores (Smith \& Aubin, 1993; Eberbach, 1998).

Após a condução do experimento, o glifosato remanescente no solo e seus possíveis metabólitos não puderam ser extraídos (Tabela 7), permanecendo como resíduo-ligado. Isto sugere que a sorção do glifosato neste solo é governada, provavelmente, por mecanismos que envolvem elevada energia de ligação. Esse comportamento do glifosato também foi observado por Prata et al. (2000b) para solos com diferentes atributos mineralógicos, com e sem oxidação da matéria orgânica.

\section{Cinética de sorção e dessorção}

Os valores do parâmetro de Elovich $[(1 / Y) \ln (X Y)] \quad(89,94$ e 94,18 \%, respectivamente para $\mathrm{PD}$ e $\mathrm{PC}$ ), associados às curvas de cinética de sorção do glifosato (Figura 7), mostram que a cinética desta molécula praticamente não apresentou sorção na fase lenta, sendo que quase a totalidade do glifosato aplicado foi sorvido no período inicial de equilíbrio, para ambos os sistemas de cultivo. A forma da curvas de cinética obtidas neste trabalho (Figura 7), caracterizadas pela elevada sorção instantânea seguida de um platô, é característica para solutos que apresentam adsorção de superfície (Sparks, 1989).

Os processos de superfície têm sido sugeridos por vários autores para explicar a sorção do glifosato, principalmente pelo fato desta ser uma molécula hidrofílica que apresenta elevados valores de coeficiente de sorção (Cheah et al, 1997; Jonge et al, 2001). No caso da ligação entre o glifosato e átomos metálicos, ou mesmo o glifosato e os óxidos de $\mathrm{Fe}$ e $\mathrm{Al}$, alguns autores têm mencionado a ligação covalente entre o grupo metilfosfônico do herbicida e os metais dos óxidos do solo como o principal mecanismo de retenção dessa molécula (Hance, 1976; Glass, 1987; Piccolo et al, 1994; Gerritse et al., 1996; Cheah et al., 1997; Jonge et al., 2001). Essa ligação apresenta elevada energia, o que vem de encontro às tentativas frustradas de extração e dessorção, cujos resultados são apresentados nas tabelas 7 e 8 , respectivamente. 

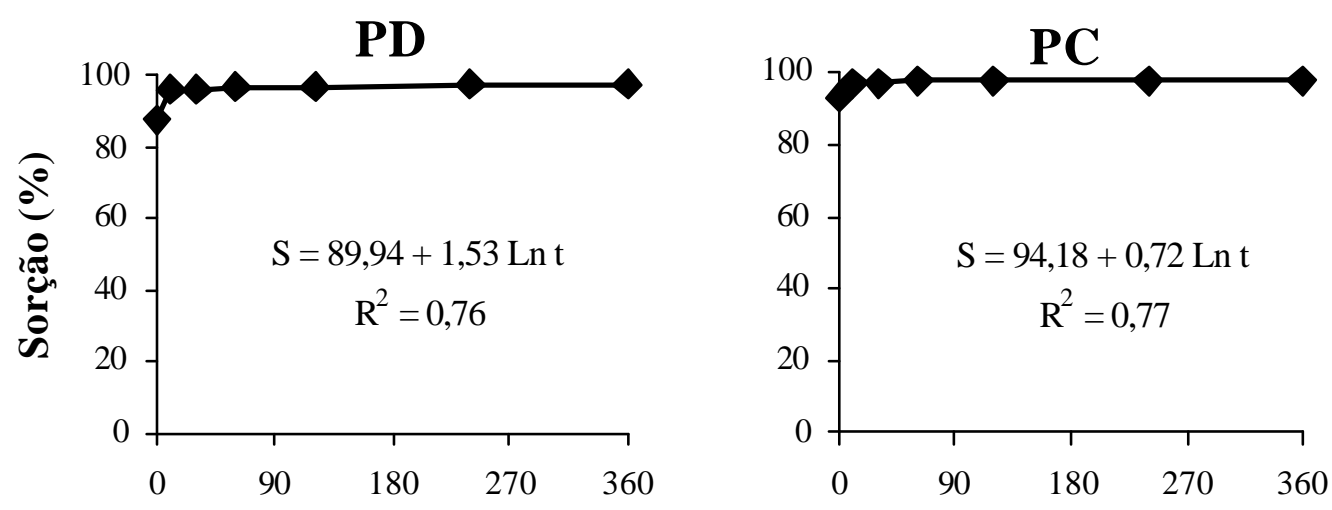

$\checkmark$ Resultados Experimentais — Modelo de Elovich

Figura 7. Cinética de sorção de glifosato com aplicação do modelo de Elovich para um Latossolo Vermelho Distroférrico mantido há 23 anos sob plantio direto (PC) ou plantio convencional (PD)

\section{Sorção/dessorção}

O modelo de Freundlich apresentou bom ajuste às isotermas de sorção do glifosato, para ambos os sistemas de cultivo (Tabela 8), sendo que a sorção desta molécula foi caracterizada por isotermas lineares $(N \sim 1$, Tabela 8$)$. A porcentagem de glifosato sorvido em relação ao total aplicado foi próximo de $97 \%$ para os dois sistemas de cultivo, sendo que não houve dessorção após 4 tentativas (Tabela 8).

Os valores de $K_{f}$-sor foram bastante elevados para ambos os sistemas de manejo de solo (162,9 e 215,7 $\mathrm{L} \mathrm{kg}^{-1}$ para PD e PC, respectivamente). Todavia, estatisticamente, observou-se $K_{f}$-sor superior no solo sob PC (Tabela 8), onde o conteúdo de carbono é menor (Tabela 5). Esta diferença para os valores de $K_{f}$ entre os dois sistemas de cultivo, embora praticamente seja muito pequena, pode ser considerada como mais um leve indício para a sugestão feita anteriormente sobre os processos de superfície envolvendo a sorção do glifosato. Neste caso, o maior conteúdo de matéria orgânica no PD poderia estar contribuindo com um melhor recobrimento dos sítios de ligação covalente dos óxidos, o que provavelmente explica os menores valores de sorção e $K_{f}$-sor, embora 
Tabela 8. Sorção e dessorção, parâmetros de Freundlich para isotermas de sorção e dessorção e índice GUS do glifosato num Latossolo Vermelho Distroférrico mantido há 23 anos sob plantio direto (PD) ou convencional (PC).

\begin{tabular}{|c|c|c|c|c|c|c|c|c|}
\hline Sistema Manejo & $S^{1 /}$ & $D^{21}$ & $K_{\mathrm{OC}}{ }^{3 /}$ & $K_{f}$-sor $^{4 \prime}$ & $N^{5 /}$ & $\mathrm{R}^{2}$ & $K_{f}-\operatorname{des}^{6 /}$ & GUS \\
\hline & \multicolumn{2}{|c|}{ …............... \% …................. } & \multicolumn{2}{|c|}{ …............. $\mathrm{L} \mathrm{kg}^{-1}$} & \multicolumn{4}{|c|}{$\mathrm{Lkg}^{-1}$} \\
\hline PD & $97,2 \pm 0,16$ & $0,00 \pm 0,0$ & $540,90 \pm 8,30$ & $162,9 \pm 8,1$ & 0,98 & $0,99 * *$ & $\mathrm{ND}^{7 /}$ & $1,63 \pm 0,01$ \\
\hline $\mathrm{PC}$ & $97,9 \pm 0,10$ & $0,00 \pm 0,0$ & $922,57 \pm 41,48$ & $215,7 \pm 2,6$ & 0,99 & $0,99 * *$ & ND & $1,46 \pm 0,03$ \\
\hline $\mathrm{DMS}^{8 /}$ & 0,24 & - & 54,71 & 11,00 & - & - & - & - \\
\hline
\end{tabular}

${ }^{1 /}$ Glifosato sorvido. ${ }^{2 /}$ Glifosato dessorvido. ${ }^{3 /}$ Constante de sorção linear normalizada para o conteúdo de carbono orgânico. ${ }^{4 /}$ Coeficiente de Freundlich para dessorção. ${ }^{5 /}$ Grau de linearidade da isoterma ${ }^{6 /}$ Coeficiente de Freundlich para dessorção. ${ }^{7 /}$ Não-determinável. ${ }^{8 /}$ Diferença mínima significativa pelo teste de Tukey $(\mathrm{p}<0,05)$. 
ainda muito elevado, para o PD em relação ao PC. Por outro lado, existem outros mecanismos de ligação importantes na sorção do glifosato, os quais muito provavelmente devem atuar concomitantemente, dado que a molécula do glifosato é um "zwitterion" fosforado (Nicholls \& Evans, 1991) e que o solo é um sistema complexo que contém diferentes tipos de sorvente (Tan, 1993). Para solos ingleses com cargas permanentes, Nicholls \& Evans (1991) observaram o decréscimo da sorção do glifosato com a redução do $\mathrm{pH}$. Os autores atribuíram esses resultados ao caráter de "zwitterion" do glifosato, que indicou a formação de ligação eletrostática entre a molécula e os colóides desse solo. Em valores de $\mathrm{pH}$ inferiores a 2, o glifosato passa a ter carga líquida positiva (Maqueda et al., 1998). Nos valores de $\mathrm{pH}$ convencionais para solos agrícolas de regiões sob clima tropical, o glifosato pode manifestar tanto carga positiva quanto negativa, atuando como um "ziwtterion", o que levar a crer também na existência de forças eletrostáticas na sorção dessa molécula para solos brasileiros. Todavia, caso este tipo de ligação se manifeste, não deve apresentar relevância para nossas condições.

Os baixos valores referentes ao índice GUS (Tabela 8) classificam o glifosato como um herbicida com baixo potencial de lixiviação nesse solo, para ambos os sistemas de cultivo (Gustafson, 1989). Valores de GUS semelhantes nesse trabalho (Tabela 8) também foram verificados por Gustafson (1989). No entanto, esse índice apresenta limitações e serve apenas como um indicativo para a lixiviação, sendo que resultados mais minuciosos sobre o movimento de pesticidas devem ser obtidos através de experimentos em colunas ou lisímetros. Uma crítica severa ao GUS para este estudo dá-se do fato de que o índice é calculado a partir de valores de $K_{\mathrm{oc}}$ e a sorção do glifosato não se relaciona com o conteúdo de matéria do solo (Prata et al., 2000b).

Apesar das evidências de baixo potencial de lixiviação do glifosato nesse estudo, caracterizadas principalmente pelas altas taxas de sorção e extração nula, o movimento vertical dessa molécula pode ser observado em casos específicos de solos arenosos com elevado volume de macroporos. A lixiviação do glifosato num solo dinamarquês, dessa natureza, foi observada por Jonge et al. (2000) em colunas de solo indeformadas. No entanto, o valor de $K_{\mathrm{f}}$ obtido para aquele solo foi elevado $\left\{59\left[\left(\mathrm{mg} \mathrm{g}^{-1}\right)\left(\mathrm{mL} \mathrm{mg}^{-1}\right)^{\mathrm{N}}\right]\right\}$ e a radioatividade, considerada como concentração de glifosato, na solução percolada da 
coluna variou proporcionalmente com a turbidez da solução, o que indica que a molécula foi lixiviada provavelmente na forma de resíduo-ligado.

\section{Teste biológico}

Os resultados do teste biológico, apresentados na forma de sintoma visual de fitotoxidez em função da concentração de glifosato aplicado ao solo (Figura 8),

mostraram que somente em concentrações superiores a $42 \mu \mathrm{g} \mathrm{g} \mathrm{g}^{-1}$ de glifosato, para ambos os sistemas de cultivo, começaram a aparecer sintomas reais de fitotoxidez. Esta concentração equivale a aproximadamente dez vezes a dose máxima recomendada no campo. Apenas para a concentração de $210 \mu \mathrm{g} \mathrm{g} \mathrm{g}^{-1}$ foi observado problemas de fitotoxidez no capim mombaça aos 24 e 84 dias após a aplicação do herbicida. Desta forma, o teste biológico vem a complementar as resultados de sorção e $t_{1 / 2}$ dis. verificados neste trabalho, mostrando relativa segurança quanto ao comportamento do glifosato nestes casos estudados. 


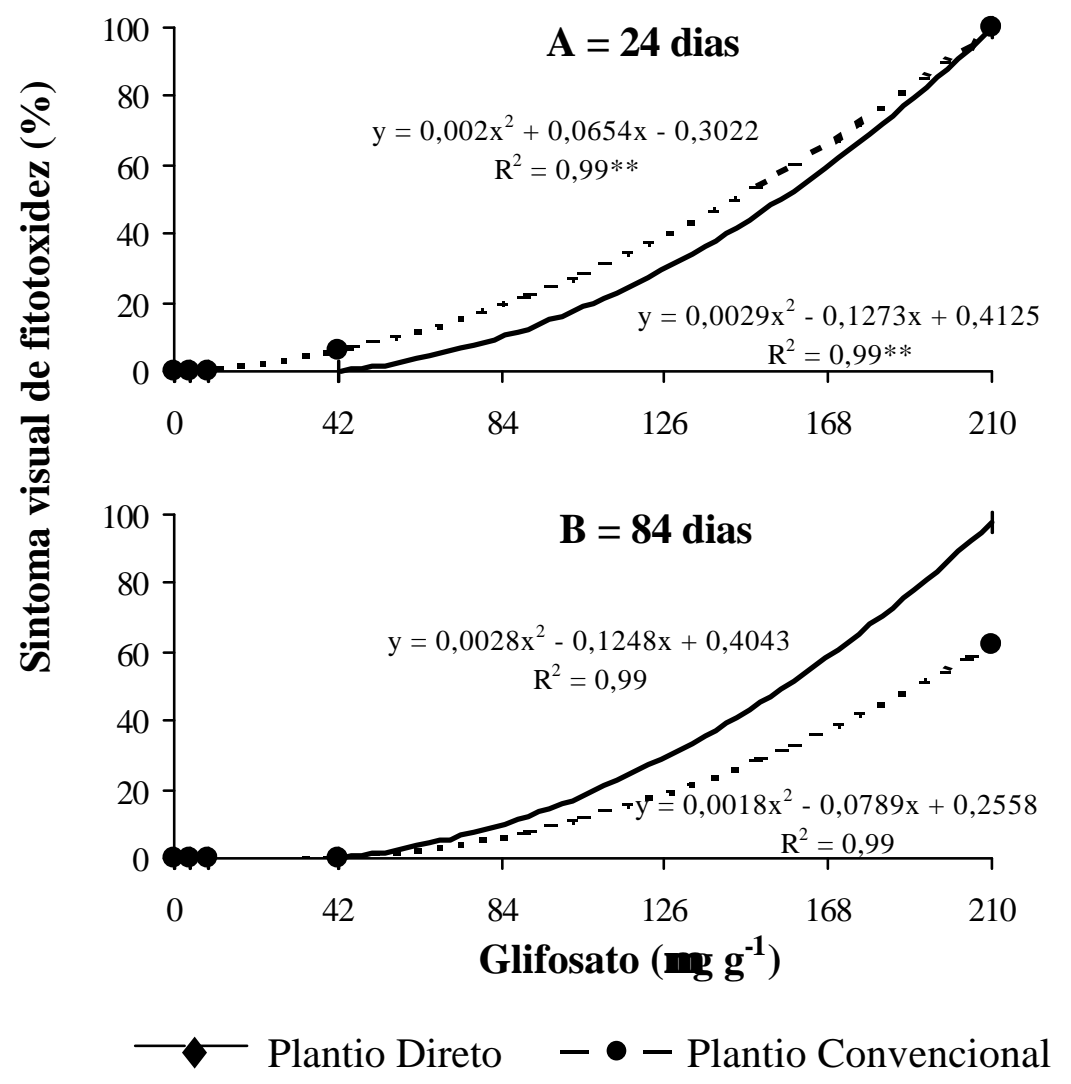

Figura 8. Sintomas visuais de fitotoxidez de glifosato em capim mombaça, observados 20 dias após a germinação, num Latossolo Vermelho Distroférrico mantido há 23 anos sob plantio direto ou convencional (A e B: 24 e 84 dias após a aplicação do glifosato no solo, respectivamente).

\subsection{Conclusões}

O sistema de plantio direto contribuiu para a aceleração da mineralização do glifosato.

O principal metabólito resultante da degradação do glifosato foi o ácido aminometilfosfônico. 
Para ambos os sistemas de cultivo, o glifosato apresentou elevada sorção, o que dificultou sua mineralização na solução do solo, permanecendo a molécula na forma de resíduo-ligado.

A cinética de sorção do glifosato é instantânea, praticamente não apresentando fase lenta.

O glifosato não apresentou fitodisponibilidade para o Panicum maximum, tanto no plantio direto como no convencional. 


\section{DESLOCAMENTO MISCÍVEL COM MODELAGEM MATEMÁTICA, SORÇÃo E DESSORÇÃO DE ATRAZINA EM LATOSSOLO VERMELHO SOB PLANTIO DIRETO E CONVENCIONAL}

\section{Resumo}

O objetivo principal deste trabalho foi estudar o deslocamento miscível, sorção e dessorção da atrazina em um Latossolo Vermelho sob plantio direto (PD) ou convencional (PC). Os objetivos específicos foram: i) modelar as curvas de lixiviação do herbicida, ii) avaliar a contribuição da sorção (sorção aos sítios em equilíbrio e nãoequilíbrio com a solução do solo e sorção irreversível) na lixiviação da atrazina, iii) determinar e modelar a distribuição da atrazina remanescente nas colunas e iv) avaliar a sorção e dessorção da atrazina pelo método "batch". Para tanto, foram conduzidos dois ensaios paralelos, sendo os tratamentos constituídos de amostras do Latossolo sob os dois sistemas de manejo. O primeiro ensaio foi o de deslocamento miscível da atrazina em colunas de solo, com utilização do íon $\mathrm{Br}^{-}$como traçador. As condições empregadas foram: solo não saturado, amostras deformadas e aplicação do soluto em pulso rápido. Aos resultados de deslocamento do traçador foi aplicado o modelo de transporte baseado na equação de convecção-dispersão, considerando o equilíbrio de sorção. Para o deslocamento da atrazina foi utilizado o modelo matemático "two-site", também baseado na equação de convecção-dispersão, entretanto, considerando o não-equilíbrio químico de sorção. Após o término da lixiviação, as colunas foram segmentadas e a atrazina residual e seus metabólitos foram extraídos, caracterizados e quantificados. No 
segundo experimento (sorção/dessorção - método "batch"), foram utilizadas 5 concentrações do herbicida, para aplicação do modelo de isotermas de Freundlich. Concluiu-se que a atrazina apresentou potencial de lixiviação no solo, independente do sistema de manejo, sendo que este potencial foi dependente da sorção nos sítios em equilíbrio e não-equilíbrio com a solução do solo. No entanto, a sorção irreversível foi mais importante que a sorção "reversível” em ambos os sítios em equilíbrio e nãoequilíbrio. A hidroxiatrazina foi o principal metabólito da atrazina e apresentou menor lixiviação que a molécula original e os outros metabólitos. Ambos os modelos de transporte foram ajustados com sucesso aos dados de deslocamento miscível do traçador e da atrazina, para ambos os sistemas de cultivo. Todavia, o modelo "two-site" superestimou a sorção irreversível (formação de resíduo-ligado), para a concentração residente na coluna. O modelo de transporte "two-site", ajustado aos dados de deslocamento miscível da atrazina, previu coeficientes de partição, para sorção, semelhantes aos gerados pelo método "batch", o que não foi verdade para a dessorção.

\section{MISCIBLE DISPLACEMENT WITH MATHEMATICAL MODELING, SORPTION AND DESORPTION OF ATRAZINE IN A BRAZILIAN OXISOL FROM NO-TILL AND CONVENTIONAL SYSTEMS}

\section{Summary}

The aim of this research was to study the miscible displacement, sorption and desorption of atrazine in a Brazilian Oxisol, which had been maintained under no-till or conventional agricultural managements for 25 years. The specific objectives were i) to fit the atrazine breakthrough curves, ii) to evaluate the contribution of sorption on the atrazine leaching (equilibrium vs nonequilibrium sorption; reversible vs irreversible sorption), iii) to measure and to predict, by mathematical modeling, the distribution of 
the residual radioactivity within the soil columns, iv) to evaluate the sorption and desorption batch experiments of atrazine. Two parallel experiments were carried out, being the treatments the Oxisol under no-till and conventional management systems. In the first experiment, we studied the miscible displacement of atrazine in soil columns, using $\mathrm{Br}^{-}$as a tracer. The experimental conditions were: non-saturated soil, disturbed samples, and solute application in fast pulse. We fitted the $\mathrm{Br}^{-}$displacement with an equilibrium convective dispersive transport model, and atrazine displacement with twosite chemical nonequilibrium dispersive convective transport model. After the leaching, the soil columns were stratified and the residual atrazine and its metabolites were extracted and characterized. In the second experiment (sorption/ desorption batch experiment), we employed 5 atrazine concentrations, in order to fit with Freundlich model for isotherms. We concluded the atrazine presented a potential leaching, in both management systems. This potential was dependent of equilibrium and nonequilibrium sorption sites. However, irreversible sorption was more important than "reversible" sorption in equilibrium and nonequilibrium sites. Hydroxyatrazine was the most important metabolite, and it was minus mobile than atrazine and the other metabolites. Both equilibrium and nonequilibrium models successfully fitted the $\mathrm{Br}^{-}$and atrazine breakthrough curves, respectively, for both management systems. However, the two-site nonequilibrium model overestimated the irreversible sorption (bound-residue formation) for resident concentration of atrazine within soil column. The two-site nonequilibrium transport model predicted partition coefficients for sorption very similar to these measured in the sorption batch experiment. This was not true for desorption data.

\subsection{Introdução}

A descoberta do poder de algumas substâncias organossintéticas para o controle de agentes indesejáveis ou nocivos como insetos, fungos, plantas daninhas etc., proporcionou a expansão das áreas cultivadas e o aumento da produção de alimentos em todo mundo. Em menos de quarenta anos, esses produtos químicos de utilização agronômica tornaram-se os insumos mais utilizados na produção agrícola de larga 
escala, tendo seu uso intensificado em meados dos anos 70. O interesse e a preocupação de cientistas do solo com o uso intenso dessas moléculas se deu tão logo elas começaram a ser utilizadas. Em 1960, já havia sessões especiais em simpósios, as quais tratavam do comportamento de pesticidas no ambiente, como as dos encontros anuais da "Sociedade Americana de Agronomia" e "Sociedade Americana de Ciência do Solo" (Cheng et al., 1990).

A dinâmica dos pesticidas no solo é bastante complexa e depende tanto das propriedades físico-químicas das moléculas, como dos atributos químicos, físicos e biológicos do solo e das variáveis ambientais. Quando as moléculas de um determinado pesticida são aplicadas no ambiente, seja da forma que for essa aplicação, o destino final, na maioria dos casos, é o solo. Já no solo, as moléculas podem seguir diferentes rotas, isto é, podem ser sorvidas aos colóides minerais e orgânicos e a partir daí passar para formas indisponíveis às plantas (fração resíduo-ligado), ou serem novamente liberadas à solução do solo, através do processo conhecido como dessorção. As moléculas também podem ser transformadas em outras moléculas, os metabólitos, normalmente de menor massa e estrutura química. O ponto final dessa transformação, naturalmente para as moléculas que atingem essa fase, é a mineralização à $\mathrm{CO}_{2}, \mathrm{H}_{2} \mathrm{O}$ e íons minerais, o que se dá, fundamentalmente, via microrganismos. Se as moléculas se encontram na solução do solo, elas podem ser absorvidas pelas raízes das plantas, ou serem lixiviadas para camadas subsuperficiais do perfil ou sofrerem escorrimento superficial, ou ainda serem volatilizadas. Tudo isso ocorre no solo simultaneamente, em intensidades diferentes.

Os estudos de comportamento de pesticidas no solo têm sido realizados sob as mais variadas condições, mas de forma geral, a finalidade dessas pesquisas vem sendo sempre relacionada com a eficiência das moléculas no controle das plantas daninhas ou com o transporte do pesticida no solo (Vereecken et al., 2001; Regitano et al., 2002). Na maior parte dos casos, os estudos de transporte estão relacionados ao movimento vertical dos pesticidas no perfil do solo, o que está estreitamente ligado à capacidade de sorção e à taxa de degradação dos mesmos (Kookana et al., 1993). Várias moléculas de pesticida 
enquadram-se como potencialmente móveis no solo, destacando-se principalmente alguns herbicidas pré-emergentes, como as triazinas (Peixoto, 2000).

Dentre os herbicidas mais utilizados no mundo, destaca-se a atrazina [2-cloro4-(etilamino)-6-(isopropilamino)-s-triazina], um herbicida amplamente utilizado no Brasil no controle de plantas daninhas nas culturas do milho e sorgo entre outras, tanto sob sistema de plantio direto como de cultivo convencional. Sua aplicação é realizada, principalmente, em pré-emergência e seu mecanismo de ação se dá pela inibição da reação de Hill, na fotossíntese (Rodrigues \& Almeida, 1995). Esta molécula apresenta baixos valores de coeficiente de sorção (entre 0,4 e 4,5 $\mathrm{L} \mathrm{kg}^{-1}$ ) e meia-vida que pode ser superior a 100 dias, dependendo do tipo de solo (Montgomery, 1997), o que a sugere um potencial de mobilidade. Aliado a isso, a atrazina é muito pouco mineralizada $\left(t_{1 / 2} \mathrm{de}\right.$ mineralização entre 9,5 e 28,3 anos, Goswani \& Green, 1971; Skipper \& Volk, 1972). No caso específico desta molécula, a $t_{1 / 2}$ de mineralização é um parâmetro de suma importância, pois um dos principais metabólitos da atrazina, a desetilatrazina, também é fitotóxico e ainda apresenta maior toxicidade para animais e humanos do que a própria molécula original (Moreau \& Mouvet, 1997).

Vários estudos de monitoramento ambiental, em áreas norte-americanas, têm mostrado a presença da atrazina e de seus metabólitos; desetilatrazina (DEA) e desisopropilatrazina (DIA), em cursos de água tanto superficiais como subsuperficiais (Thurman et al., 1991; Thurman et al., 1994; Cai et al., 1994; Lerch et al., 1998). No entanto, resultados desta natureza são praticamente inexistentes para as condições brasileiras.

A extensão da mobilidade da atrazina está relacionada ao conteúdo de matéria orgânica do solo (Moreau \& Mouvet, 1996; Mersie \& Seybold, 1996), o qual, por sua vez, também está envolvido na metabolização deste herbicida. A metabolização da atrazina em hidroxiatrazina (HA), seu principal metabólito (Lerch et al., 1999), ocorre principalmente via hidrólise química e é catalisada pelos processos de sorção (devido à matéria orgânica) e por baixos valores de pH (Lerch et al., 1998). Martin-Neto et al. (2001) mostraram que a transferência de prótons entre a atrazina e as substâncias 
húmicas do solo pode contribuir na metabolização da atrazina em HA e aumentar sua sorção, mostrando que a matéria orgânica pode atuar no retardamento da lixiviação da atrazina de diferentes maneiras.

Uma maneira de se verificar o potencial de transporte de um pesticida, ou sua movimentação vertical, é através dos estudos de deslocamento miscível. Esta técnica estuda o deslocamento de um fluído contendo um soluto, num meio poroso, pelo mesmo fluído sem o soluto (Nielsen \& Biggar, 1961). Os experimentos de deslocamento miscível são, normalmente, realizados em colunas de solo e produzem, como principal resultado, as curvas "breakthrough" (BTC). A essas curvas podem ser ajustados modelos matemáticos, para explicar o transporte do soluto no solo (Ma \& Selim, 1996; MeyerWindel et al., 1999). O termo "breakthrough", empregado para as curvas, não tem uma tradução ou um nome comumente usado na literatura brasileira, portanto, deste ponto em diante, designaremos às curvas "breakthrough" o nome de "curvas de lixiviação".

Vários de modelos de simulação, capazes de predizer a lixiviação de solutos, têm sido verificados na literatura e são geralmente classificados, de acordo com sua finalidade, em modelos de pesquisa ou de "screening" (Addiscot \& Wagenet, 1985). Os modelos de pesquisa são de valor particular e não só permitem uma previsão refinada da lixiviação, como também fornecem parâmetros relevantes na interpretação de mecanismos específicos envolvidos nos processos de transporte (Kookana et al., 1993).

A descrição dos fenômenos de sorção é uma crítica de muitos modelos de transporte, visto que este processo tem sido extremamente simplificado nas equações, as quais assumem o estabelecimento instantâneo do equilíbrio de sorção durante o transporte. No entanto, em se tratando do movimento de moléculas orgânicas no solo, vários trabalhos têm apontado o transporte não-ideal, caracterizado por curvas de lixiviação assimétricas (Mersie et al., 1999; Meyer-Windel et al., 1999; Vereecken et al., 2001).

Equações que consideram o não-equilíbrio de sorção, fundamentadas na forma de um modelo bicontínuo de algum tipo, representadas por processos químicos (sorção em dois diferentes tipos de sítio de sorção, um em equilíbrio direto com a solução - sorção 
instantânea; e outro em não-equilíbrio - sorção dependente do tempo) ou físicos (a matriz do solo consistindo de uma região onde a água se move e outra onde não há o movimento da água, mas há o movimento do soluto) têm sido usados com sucesso para prever o transporte de solutos que reagem com a matriz (Cameron \& Klute, 1977; van Genuchten et al., 1977; Kookana et al., 1993; Guo \& Wagenet, 1999). Ambos os modelos, baseados nos processos químicos e físicos de não-equilíbrio de sorção, podem ser descritos numa mesma equação matemática (Nkedi-Kizza et al., 1984). Alguns experimentos têm mostrado que o não-equilíbrio de sorção, para um grande número de pesticidas, é dependente do tempo está relacionado ao fenômeno de difusão dos pesticidas para o interior das frações orgânicas do solo (Brusseau \& Rao, 1991).

Alguns modelos matemáticos, baseados na equação de convecção-dispersão (ECD), além de modelar as curvas de lixiviação para muitos casos (Ma \& Selim, 1996), podem até mesmo prever a distribuição da fração remanescente do soluto, nas colunas, após o término da percolação (Pignatello et al., 1993).

\subsubsection{Teoria dos modelos de transporte em estudos de deslocamento miscível}

\subsubsection{Modelo de transporte de solutos baseados na equação de convecção- dispersão (ECD) para solutos que apresentam equilíbrio de sorção}

O transporte unidimensional de solutos por convecção-dispersão num meio poroso homogêneo, com fluxo contínuo e conteúdo de água uniforme, para solutos com equilíbrio de sorção linear e que não apresentam degradação, pode ser descrito pela ECD seguinte:

$$
R \frac{\partial C}{\partial t}=D \frac{\partial^{2} C}{\partial z^{2}}-v \frac{\partial C}{\partial z}
$$

em que, $C$ é a concentração do soluto na fase líquida, $t$ é o tempo, $z$ é a profundidade, $R$ é o fator de retardação do soluto para equilíbrio de sorção linear $\left(R=1+\rho K_{d} / \theta\right)$, $\rho$ é a densidade do solo, $\theta$ é o conteúdo de água nos poros, $K_{d}$ é o coeficiente de sorção 
linear, $D$ é o coeficiente aparente de dispersão e $v$ é a velocidade da água nos poros derivado do fluxo de Darcy, $J_{w}\left(v=J_{w} \rho^{-1}\right)$.

\subsubsection{Modelo de transporte de solutos baseados na equação de convecção- dispersão (ECD) para solutos que apresentam não-equilíbrio de sorção}

O transporte de solutos no solo é assumido ser afetado pelos processos de nãoequilíbrio de sorção, decorrentes de fatores químicos e físicos (Nielsen et al.,1986; Kookana et al., 1993; Vereecken et al., 2001). Os modelos de transporte de solutos, baseados no não-equilíbrio químico de sorção, assumem que este não-equilíbrio é devido ao tempo da reação de sorção. Nesse caso, os sorventes são assumidos como tendo dois tipos de sítios de sorção. Um onde a sorção é instantânea e outro onde a sorção apresenta taxa limitada (Cameron \& Klute, 1977). Este segundo, teoricamente, representa a difusão lenta do soluto para o interior das substâncias húmicas e/ou dos microagregados argilo-húmicos do solo. A sorção em taxa limitada é representada por uma equação de primeira ordem e a sorção instantânea por um modelo de isoterma qualquer, normalmente a de Freundlich (Kookana et al., 1993). Por outro lado, o nãoequilíbrio físico de sorção explica a assimetria das BTCs pela presença de duas regiões fisicamente distintas dentro do meio poroso, uma onde a água move-se (região móvel) e outra onde a água não se move (região imóvel ou estagnada). Na região estagnada, embora a água não se mova por convecção-dispersão, o soluto pode se mover por difusão (van Genuchten \& Wierenga, 1976; Kookana et al., 1993).

\subsection{Modelo "Two-site/Two-region" para transporte de solutos no solo}

Nesse modelo, "two-site" refere-se ao efeito dos processos químicos sobre o nãoequilíbrio de sorção e "two-region" diz respeito ao efeito dos processos físicos.

Considerando primeiramente os processos químicos, a sorção nos dois tipos de sítio (equilíbrio e não-equilíbrio) pode ser descrita pelas seguintes equações:

$$
S_{1}=f K C
$$




$$
\frac{d S_{2}}{d t}=k_{1} S_{1}-k_{2} S_{2}
$$

em que $S_{1}$ e $S_{2}$ são as concentrações sorvidas aos sítios em equilíbrio e em nãoequilíbrio, respectivamente; $f$ é a fração total de sítios em equilíbrio em relação a de nãoequilíbrio; e $k_{1}$ e $k_{2}$ são as respectivas constantes de sorção para os dois diferentes sítios de sorção.

Do lado físico, a sorção em ambas as regiões, dinâmica e estagnada, é assumida ser linear e reversível, e pode ser descrita pelas seguintes equações:

$$
\begin{gathered}
S_{m}=K C_{m} \\
S_{i m}=K C_{i m}
\end{gathered}
$$

em que os subscritos $m$ e im representam as fases dinâmica (móvel) e estagnada (imóvel), respectivamente.

Nkedi-Kizza et al. (1984) mostraram que ambos os modelos (baseados nos processos químico e físico) podem ser agrupados na mesma equação matemática perante a introdução de variáveis não-dimensionáveis. As duas seguintes equações nãodimensionáveis podem ser empregadas para simulação do transporte de solutos no solo:

$$
\begin{gathered}
\beta R \frac{\partial C_{1}}{\partial t}+(1-\beta) R \frac{\partial S_{2}}{\partial t}=\frac{1}{P} \frac{\partial^{2} C_{1}}{\partial X^{2}}-\frac{\partial C_{1}}{\partial X}-\mu_{1} C \\
(1-\beta) R \frac{\partial S_{2}}{\partial t}=\omega\left(C_{1}-S_{2}\right)
\end{gathered}
$$

Para os processos físicos e químicos, o modelo considera as variáveis dimensionáveis como:

Processos físicos Processos químicos

$$
P=\frac{v_{m} L}{D_{m}} \quad P=\frac{v L}{D}
$$




$$
\begin{aligned}
& X=\frac{z}{L} \\
& X=\frac{z}{L} \\
& C_{1}=\frac{C_{m}}{C_{0}} \\
& C_{1}=\frac{C}{C_{0}} \\
& S_{2}=\frac{C_{i m}}{C_{0}} \\
& S=\frac{S_{2}}{(1-f) K C_{0}} \\
& R=1+\frac{\rho K}{\theta} \\
& R=1+\frac{\rho K}{\theta} \\
& \beta=\frac{\left(\boldsymbol{\theta}_{m}+f \rho K\right)}{(\boldsymbol{\theta}+\rho K)} \\
& \beta=\frac{\left[1+f\left(\frac{\rho}{\theta}\right) K\right]}{R} \\
& \omega=\frac{(\alpha L)}{\left(\boldsymbol{\theta}_{m} v_{m}\right)} \\
& \omega=\frac{k_{2}(1-\beta) R L}{v} \\
& \mu_{1}=\frac{L\left(\boldsymbol{\theta}_{m} \mu_{2, m}+f \rho K_{d} \mu_{s, m)}\right.}{\theta} \quad \mu_{1}=\frac{L\left(\theta \mu_{2}+f \rho K_{d} \mu_{s}\right)}{\theta}
\end{aligned}
$$

em que os símbolos não definidos previamente são: $P=$ relação entre o transporte convectivo e dispersivo; $L=$ fator de profundidade para a coluna (é considerado como unitário); $C_{0}=$ concentração aplicada do soluto; $C_{1}=C / C_{0} ; \alpha=$ coeficiente de transferência de massas; $\beta=$ fração de retardação instantânea, $\omega=$ coeficiente de Damköhler (relação do tempo de residência hidrodinâmica com as características de tempo de sorção) e $\mu_{1}=$ constante de primeira ordem de transferência de massa; $\mu_{2}=$ constante de velocidade de dissipação; $\mu_{\mathrm{s}}=$ constante de transferência de massa para a fase sorvida.

O objetivo principal desta pesquisa foi verificar o deslocamento miscível, sorção e dessorção da atrazina num Latossolo Vermelho cultivado há 25 anos sob plantio direto ou convencional. Os objetivos específicos foram: i) modelar as curvas de lixiviação da atrazina, ii) avaliar a contribuição da sorção na lixiviação do herbicida (sorção aos sitos 
em equilíbrio e não-equilíbrio com a solução do solo, e sorção irreversível), iii) determinar e prever, através de modelagem matemática, a distribuição da atrazina remanescente nas colunas e iv) determinar a sorção e dessorção da atrazina através da técnica "batch".

\subsection{Material e Métodos}

Foram conduzidos dois experimentos nos laboratórios do Institut für Chemie und Dynamik der Geosphäre IV: Agrosphäre/ Forchungszentrum Jülich, Jülich, Alemanha. No primeiro deles, estudoutse o deslocamento miscível do $\mathrm{Br}^{-}$(íon empregado como traçador) e da atrazina em colunas de solo e, no segundo, foi verificada a sorção e a dessorção da atrazina, através da técnica "batch". Os tratamentos para ambos os experimentos foram amostras deformadas de um Latossolo Vermelho sob plantio direto e convencional.

\subsubsection{Solo}

Foram coletadas amostras deformadas de um Latossolo Vermelho Distroférrico, da região de Ponta Grossa, PR, cultivado há 25 anos sob plantio direto e convencional (áreas adjacentes de mesma topografia). As amostras foram coletadas na camada entre 0 e $20 \mathrm{~cm}$ de profundidade e, posteriormente, foram secas ao ar e passadas em peneira com malha de $2 \mathrm{~mm}$. Alguns atributos inerentes ao solo, de relevância para a sorção e movimento de pesticidas no solo, foram determinados e são apresentados na Tabela 9. Os atributos químicos e granulométricos foram caracterizados de acordo com Raij \& Quaggio (1983) e Camargo et al. (1986), respectivamente. O Fe total $\left(\mathrm{Fe}_{2} \mathrm{O}_{3}\right)$ e $\mathrm{Al}$ total $\left(\mathrm{Al}_{2} \mathrm{O}_{3}\right)$ foram extraídos com $\mathrm{H}_{2} \mathrm{SO}_{4} 18 \mathrm{~mol} \mathrm{~L}^{-1}$ (Vettori, 1969) e os minerais de argila predominantes foram identificados por difração de raios-X (Jackson, 1969). 
Tabela 9. Caracterização química, granulométrica e mineralógica de um Latossolo Vermelho Distroférrico, cultivado há 25 anos sob plantio direto ou convencional

\begin{tabular}{|c|c|c|c|c|c|c|c|c|c|}
\hline $\begin{array}{l}\text { Sistema de } \\
\text { manejo }\end{array}$ & $\mathrm{pH}_{\mathrm{CaCl} 2}$ & $\begin{array}{l}\text { Carbono } \\
\text { Orgânico }\end{array}$ & CTC & Areia & Silte & Argila & $\mathrm{Al}_{2} \mathrm{O}_{3}$ & $\mathrm{Fe}_{2} \mathrm{O}_{3}$ & $\begin{array}{c}\text { Minerais de } \\
\text { argila }\end{array}$ \\
\hline & & $\mathrm{g} \mathrm{kg}^{-1}$ & $\mathrm{mmol}_{\mathrm{c}} \mathrm{dm}^{-3}$ & ........ & $\ldots .$. &.. $\mathrm{g} \mathrm{kg}^{-1}$ & & $\cdots$ & \\
\hline Plantio Direto & 5,0 & 26,0 & 130,4 & 460 & 70 & 470 & 158,1 & 64,7 & $\mathrm{Ct}^{1 /} ; \mathrm{Gb}^{2 /} ; \mathrm{VHI}^{3 /}$ \\
\hline Convencional & 5,1 & 22,0 & 101,2 & 380 & 60 & 560 & 189,7 & 87,4 & $\mathrm{Ct} ; \mathrm{Gb} ; \mathrm{VHI}$ \\
\hline
\end{tabular}

${ }^{1 /}$ Caulinita. ${ }^{2 /}$ Gibsita. ${ }^{3 /}$ Vermiculita com hidroxila nas intercamadas. 


\subsubsection{Pesticida e padrões analíticos}

O herbicida atrazina [2-cloro-4-(etilamino)-6-(isopropilamino)-s-triazina] (Figura 9) foi utilizado, em ambos os experimentos, como mistura isotópica das moléculas frias e radiomarcadas. As moléculas radioativas apresentaram marcação uniforme nos carbonos do anel $\left({ }^{14} \mathrm{C}\right)$. Ambas as moléculas apresentaram pureza analítica superior a

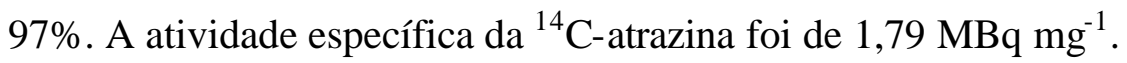

Para o preparo das soluções-estoque, a atrazina e os padrões analíticos de desetilatrazina (DEA) e desisopropilatrazina (DIA) foram dissolvidos em acetona. A hidroxiatrazina (HA) foi dissolvida em $\mathrm{HCl} 0,1 \mathrm{~mol} \mathrm{~L}^{-1}$. A pureza analítica dos padrões dos metabólitos foi $>99 \%$.

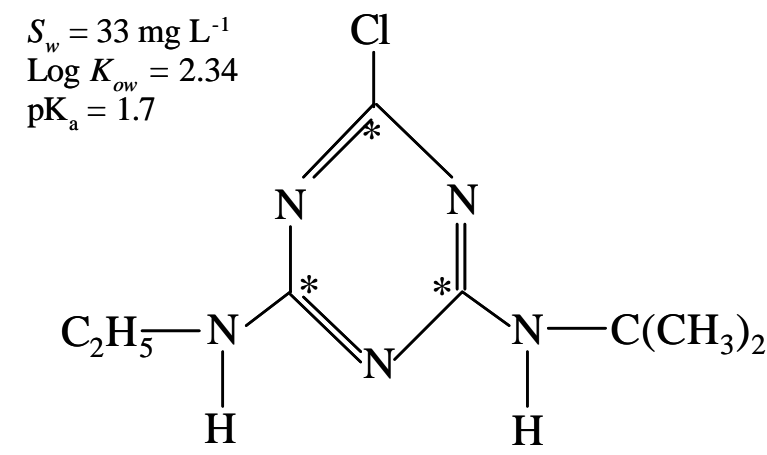

Figura 9. Fórmula molecular, solubilidade em água $\left(S_{\mathrm{w}}\right)$, coeficiente de partição hidrofóbica $\left(\log \mathrm{K}_{\mathrm{ow}}\right.$ ) e potencial da constante de dissociação $\left(\mathrm{p} K_{\mathrm{a}}\right)$ da atrazina [2-cloro-4-(etilamino)-6-(isopropilamino)-s-triazine].* Posição do ${ }^{14} \mathrm{C}$.

\subsubsection{Experimento de deslocamento miscível}

O experimento foi conduzido em delineamento inteiramente casualizado, em triplicata, sendo os tratamentos constituídos de amostras (deformadas) de um Latossolo Vermelho Distroférico sob plantio direto (PD) e convencional (PC).

O ensaio foi constituído de duas fases. Na primeira, foi estudada a movimentação do $\mathrm{Br}^{-}$, íon utilizado como traçador, e na segunda, a do pesticida. Para tanto, foram 
utilizadas colunas de vidro de $5 \mathrm{~cm}$ de diâmetro, paredes de $2 \mathrm{~mm}$ de espessura e com 40 $\mathrm{cm}$ de comprimento. As colunas apresentaram extremidade afunilada, formando bico de aproximadamente $5 \mathrm{~cm}$ de comprimento. Para o preenchimento das colunas, foi acondicionada uma camada de lã de vidro, seguida de uma camada de areia esterilizada, na parte inferior afunilada. Com o auxílio de um funil de haste longa e de um martelo de borracha, as colunas foram preenchidas com as amostras de terra até o adicionamento de uma massa de solo correspondente a altura de $20 \mathrm{~cm}$. Depois de preenchidas, uma nova camada de lã de vidro foi acondicionada na superfície da camada de solo, para reduzir o efeito do impacto das gotas de água. Subseqüentemente, a base das colunas foi imersa em água destilada, de forma que a água subisse por capilaridade até o ápice da mesma.

A aplicação do $\mathrm{Br}^{-}$foi realizada utilizando-se uma solução de $\mathrm{KBr} 0,19 \mathrm{~mol} \mathrm{~L}^{-1}$, da qual foram aplicados $10 \mathrm{~mL}$ em pulso rápido. Imediatamente após a aplicação, foi dado início a lixiviação, através do bombeamento de $\mathrm{H}_{2} 0$ destilada nas colunas por bomba peristáltica. A coleta da solução percolada foi realizada a cada 2 horas, até 84 horas após o início do processo de lixiviação, quando praticamente toda a concentração de $\mathrm{Br}^{-}$foi recuperada. Para a determinação do $\mathrm{Br}^{-}$, a separação do íon foi feita por cromatografia iônica (Cromatógrafo Dionex 4000i com CMD-I), utilizando-se précoluna IonPac AG9-HC e coluna de separação IonPac AS9-HC, ambas Dionex, Idstein. A fase móvel utilizada foi solução de $\mathrm{Na}_{2} \mathrm{CO}_{3} 9 \mathrm{mmol} \mathrm{L}^{-1}$, isocrático, com fluxo de 1 $\mathrm{mL} \min ^{-1}$ à $25{ }^{\circ} \mathrm{C}$. A detecção do $\mathrm{Br}^{-}$foi procedida por condutividade. $\mathrm{O}$ tempo de retenção foi de 11,6 min e o limite de detecção foi de $0,05 \mathrm{mg} \mathrm{L}^{-1}$.

Imediatamente após as 84 horas iniciais de lixiviação do traçador, e sem interrupção do fluxo, foi realizada a aplicação da atrazina. As novas coletas da solução percolada (duas de $10 \mathrm{~mL}$ para cada coluna) foram realizadas a cada 12 horas, até que a lixiviação fosse reduzida a aproximadamente $10 \%$ da máxima concentração lixiviada. Às alíquotas coletadas da solução percolada $(10 \mathrm{~mL})$ foram misturados $10 \mathrm{~mL}$ de solução cintiladora (Insta-Gel XF), para detecção da radioatividade, por espectrometria de cintilação líquida (ECL) em cintilador Packard 2500 TR. Com base na atividade específica da ${ }^{14} \mathrm{C}$-atrazina, a radioatividade foi convertida para massa do herbicida. Os 
detalhes experimentais da lixiviação do traçador e do herbicida estão descritos na Tabela 10.

Tabela 10. Condições experimentais para o estudo de deslocamento miscível de brometo e atrazina, em colunas preenchidas com amostras de um Latossolo Vermelho Distroférrico cultivado há 25 anos sob plantio direto (PD) ou convenional (PC)

\begin{tabular}{ll}
\hline Profundidade das colunas de solo & $0,20 \mathrm{~m}$ \\
Diâmetro das colunas & $0,051 \mathrm{~m}$ \\
Massa de terra por coluna & $483,0 \mathrm{~g}(\mathrm{PD}) ; 498,4 \mathrm{~g}(\mathrm{PC})$ \\
Densidade do solo & $1,18 \mathrm{~g} \mathrm{~cm}^{-3}(\mathrm{PD}) ; 1,22 \mathrm{~g} \mathrm{~cm}^{-3}(\mathrm{PC})$ \\
Porosidade & $0,412(\mathrm{PD}) ; 0,408(\mathrm{PC})$ \\
Fluxo de Darcy & $3,48 \mathrm{~mm} \mathrm{~h}^{-1}$ \\
Velocidade da água nos poros & $10,55 \mathrm{~mm} \mathrm{~h}^{-1}$ \\
Massa aplicada de Br- & $43,54 \mathrm{~g} \mathrm{~m}^{-2}$ \\
Massa de atrazina aplicada & $0,4 \mathrm{~g} \mathrm{~m}^{-2}\left(0,32 \mathrm{kBq} \mathrm{g}^{-1}\right)$ \\
\hline
\end{tabular}

Com objetivo de se determinar a natureza da radioatividade percolada, amostras da solução lixiviada, nos períodos de 192, 248 e 300 horas após a aplicação da atrazina (períodos de maior lixiviação), foram concentradas em rotavapor $\left(40^{\circ} \mathrm{C}\right)$ e sub-alíquotas $(100 \mu \mathrm{L})$ foram utilizadas para a elaboração da placas de cromatografia de camada delgada (TLC). As placas foram feitas seguindo o sistema de co-cromatografia. Este sistema consistiu da aplicação das amostras em faixas, com aplicação dos padrões analíticos dos metabólitos em faixas sobrepostas às faixas das amostras. A faixa de sobreposição abrangeu metade das faixas de aplicação da amostra e dos padrões. O sistema de solventes usado na eluição das placas foi composto por clorofórmio: acetona: ácido acético: água (relação 50: 30: 15: 5) e a quantificação da atrazina e dos metabólitos foi feita por radiobioimagem (Fujix BAS 1000).

Após o período de lixiviação, o solo foi retirado das colunas com ar pressurizado, e secionado em 4 camadas de $5 \mathrm{~cm}$ de comprimento. Para cada camada, foi procedida uma dessorção com $\mathrm{CaCh}_{\text {0,01 }}$ mol L $\mathrm{L}^{-1}$ (relação solução: solo = 2), seguida de duas 
extrações com acetonitrila: água (relação 4: 1), empregando a mesma relação solução: solo usada na dessorção. Tanto para a dessorção quanto para as extrações, o sistema foi agitado durante 2 horas a $200 \mathrm{rpm}$, em agitador horizontal, e centrifugado a $10.000 \mathrm{rpm}$ por 15 minutos. As frações extraídas foram misturadas e alíquotas de $10 \mathrm{~mL}$ das frações dessorvida e extraída foram utilizadas para a determinação da radioatividade presente, por ECL. Posteriormente, ambas as frações foram concentradas em rotavapor $\left(40^{\circ} \mathrm{C}\right) \mathrm{e}$ foram procedidas as placas de TLC, em co-cromatografia, para verificação da metabolização da molécula nessas duas frações.

O solo remanescente das extrações foi seco ao ar e pulverizado em almofariz de porcelana. Três alíquotas de 0,5 $\mathrm{mg}$ foram oxidadas em oxidador biológico para posterior determinação da radioatividade remanescente por ECL. Com isso, pôde-se fechar o balanço de radioatividade e quantificar a fração resíduo- ligado do herbicida.

Com o solo remanescente das extrações, contendo a fração resíduo-ligado da atrazina, foi procedido um fracionamento físico, por sedimentação. Este fracionamento proporcionou a subdivisão das amostras em três fases: fase sedimento (partículas $>20$ $\mu \mathrm{m})$, fase microagregado $(20-2 \mu \mathrm{m})$ e fase coloidal $(<2 \mu \mathrm{m})$. Para tal, foi adicionada uma massa de solo de $100 \mathrm{~g}$ e $800 \mathrm{~mL}$ de água destilada em frascos Schott de $1 \mathrm{~L}$ (o volume de água correspondeu à uma altura de coluna de água de $12 \mathrm{~cm}$ ), agitando-se a mistura durante 6 horas à $150 \mathrm{rpm}$. Após a agitação, aguardou-se 6 min e, com auxílio de uma pipeta, a suspensão sobrenadante foi retirada, permanecendo no fundo dos frascos uma massa de solo, a fase sedimento. A fração suspensa, retirada dos frascos, foi transferida para outro frasco Schott e, após 12 h de nova sedimentação, o sobrenadante foi transferido de recipiente. A nova fração sedimentada no fundo do frasco constituiu a fase microagregado e a fração suspensa a fase coloidal. Os períodos de sedimentação foram obtidos a partir da altura de coluna de água, com base na lei de Stokes (Lagaly et al., 1997). As três fases fracionadas foram liofilizadas, suas massas foram anotadas e, após a oxidação em oxidador biológico, a radioatividade remanescente foi detectada por ECL. Desta forma, pôde-se verificar a distribuição da fração resíduo-ligado de acordo com o tamanho das partículas do solo. 


\subsubsection{Experimento de sorção/ dessorção}

O ensaio foi conduzido seguindo o método "batch", em delineamento inteiramente casualizado, com três repetições. Os tratamentos foram constituídos de amostras de um Latossolo Vermelho Distroférrico sob plantio direto (PD) ou convencional (PC). Para o estabelecimento das isotermas de sorção, foram empregadas 5 concentrações da mistura isotópica $\left({ }^{14} \mathrm{C}\right.$-atrazina + atrazina fria): 0,$14 ; 0,25 ; 0,36 ; 0,68 \mathrm{e}$ $2,38 \mathrm{mg} \mathrm{L}^{-1}$, com três repetições. A relação solo: $\mathrm{CaCh}_{2} 0,01 \mathrm{~mol} \mathrm{~L}^{-1}$, tempo de agitação de equilíbrio e radioatividade aplicada foram de 1: $5,24 \mathrm{~h}$ e $0,24 \mathrm{kBq} \mathrm{mL}^{-1}$, respectivamente. Após o período de agitação, a radioatividade na solução de equilíbrio foi determinada, em alíquotas de $1 \mathrm{~mL}$, por espectrometria de cintilação líquida (ECL).

Os testes de dessorção foram realizados apenas para a concentração de 0,68 mg $\mathrm{L}^{-1}$, repetindo-se 4 vezes. As condições experimentais foram as mesmas abordadas para a sorção.

\subsubsection{Análise dos dados}

O programa CXTFIT 2.0 (Toride et al., 1995) foi utilizado para modelar as curvas de lixiviação do brometo e da atrazina, para estimar os parâmetros de transporte e para prever a distribuição do herbicida residente nas colunas após a lixiviação.

Para estimar o deslocamento do traçador e modelar sua curva de lixiviação, foi utilizado o modelo de transporte baseado na equação de convecção-dispersão, considerando o equilíbrio de sorção (eq. 36). Para atrazina, em função do deslocamento do traçador ter mostrado não haver não-equilíbrio físico nas colunas (curvas de lixiviação simétricas), a estimativa do deslocamento do herbicida e a modelagem de suas curvas de lixiviação foram procedidas através de uma simplificação das equações (41) e (42). Desta forma, o deslocamento da atrazina foi modelado utilizando-se apenas o modelo baseado no não-equilíbrio químico ("two-site"):

$$
\left(1+\frac{f \rho K_{d}}{\theta}\right) \frac{\partial C}{\partial t}=D \frac{\partial^{2} C}{\partial z^{2}}-v \frac{\partial C}{\partial z}-\frac{\alpha \rho}{\theta}\left[(1-f) K_{d} C-S_{2}\right]-\mu_{l} C
$$




$$
\frac{\partial S_{2}}{\partial t}=\alpha\left[(1-f) K_{d} C-S_{2}\right]
$$

Os parâmetros de entrada das equações usadas tanto para a modelagem do deslocamento do $\mathrm{Br}^{-}$quanto a da atrazina encontram-se na Tabela 11.

Tabela 11. Parâmetros usados como dados de entrada nos modelos de transporte baseados na equação de concecção-dispersão (ECD) que consideram o equilíbrio e o não-equilíbrio de sorção, para simulação das curvas de lixiviação de $\mathrm{Br}^{-}$e atrazina, respectivamente, em colunas preenchidas com amostras de um Latossolo Vermelho Distroférrico sob plantio direto (PD) ou convencional $(\mathrm{PC})$

\begin{tabular}{|c|c|c|c|c|c|c|c|c|c|}
\hline \multirow{2}{*}{$\begin{array}{c}\text { Sistema de } \\
\text { manejo }\end{array}$} & \multicolumn{3}{|c|}{ ECD (equilíbrio) } & \multicolumn{6}{|c|}{ ECD ("Two-site" - não-equilíbrio) } \\
\hline & $v$ & $D$ & $R$ & $v^{11}$ & $D^{21}$ & $R^{3 /}$ & $\beta^{4 /}$ & $\omega^{5 /}$ & $\mu_{1}{ }^{6 /}$ \\
\hline & $\mathrm{mm} \mathrm{h}^{-1}$ & $\mathrm{~mm}^{2} \mathrm{~h}^{-}$ & & $\mathrm{mm} \mathrm{h}^{-1}$ & $\mathrm{~mm}^{2} \mathrm{~h}^{-1}$ & & & & $\operatorname{dia}^{-1}$ \\
\hline PD & 10,55 & 100 & 1,0 & 7,60 & 14,23 & 8,0 & 0,5 & 0,01 & 0,009 \\
\hline $\mathrm{PC}$ & 10,55 & 100 & 1,0 & 7,05 & 15,23 & 8,0 & 0,5 & 0,01 & 0,007 \\
\hline
\end{tabular}

${ }^{1 /}$ Velocidade da água nos poros (estipulado pela modelagem das curvas de lixiviação do $\mathrm{Br}^{-}$). ${ }^{2 /}$ Coeficiente de dispersão aparente (estipulado pela modelagem das curvas de lixiviação do $\mathrm{Br}^{-}$). ${ }^{3 /}$ Fator de retardo (Calculado com base em valores de $K_{\mathrm{d}}$ obtidos na literatura). ${ }^{4 /}$ Fração de retardação instantânea (parâmetro assumido). ${ }^{5 /}$ Parâmetro de Damköhler. ${ }^{6 /}$ Constante de primeira ordem de transferência de massa (parâmetro assumido com base na meia-vida observada na literatura).

Para proposição das soluções analíticas no CXTFIT 2.0, as condições iniciais relacionadas as curvas de lixiviação, associadas às equa ções (36), (45) e (46) foram:

$$
\begin{gathered}
C(z=0, t)=C_{0} ; \text { para } 0<t<t_{0} \\
C(z=0, t)=0 ; \text { para } t>t_{0}
\end{gathered}
$$


Os parâmetros obtidos da modelagem da curva de lixiviação da atrazina foram usados na previsão da distribuição da atrazina remanescente nas colunas após a lixiviação. A concentração de atrazina na solução do solo $(\theta C)$, a massa sorvida aos sítios em equilíbrio $\left(\rho f K_{d} C\right.$ ) e a massa sorvida aos sítios em não-equilíbrio $\left(\rho S_{2}\right)$, foram previstos através da solução das equações (45) e (46), usando as seguintes condições iniciais:

$$
\begin{gathered}
C(z=0, t)-\left.\frac{D}{v} \frac{\partial C}{\partial z}\right|_{z=0}=C_{0} \text { para } 0<t<t_{0} \\
C(z=0, t)-\left.\frac{D}{v} \frac{\partial C}{\partial z}\right|_{z=0}=0 \text { para } t>t_{0}
\end{gathered}
$$

A massa de atrazina na solução do solo e as massas sorvidas aos sítios em equilíbrio e não-equilíbrio com a solução (sorção "reversível”), foram previstas para as profundidades da coluna utilizando-se as médias de $\theta C, \rho f K_{d} C, \rho S_{2}$. A massa de atrazina sorvida irreversivelmente nas camadas, foi prevista por diferença entre a concentração total remanescente nas colunas após a lixiviação e as demais previstas pela modelagem $\left(C_{1}+S_{1}+S_{2}\right)$.

Os resultados de sorção e dessorção foram ajustados ao modelo de isotermas de Freundlich (eq. 28). Os valores de coeficiente de partição, $K_{d}\left(K_{d}=S / C e\right)$, foram calculados com base na média das cinco concentrações utilizadas.

\subsection{Resultados e Discussão}

\subsubsection{Deslocamento miscível}

Os balanços de massas $\left({ }^{14} \mathrm{C}\right)$ calculado e previsto pelo programa CXTFIT, para ambos os sistemas de cultivo, são apresentados na Tabela 14. A lixiviação e formação de resíduo-ligado de atrazina fram levemente influenciados pelo sistema de manejo de solo. Entretanto, o fato desta pesquisa ter sido conduzida sob condições de amostra deformada pode ter mascarado o principal efeito diferencial destes dois sistemas de cultivo na

lixiviação de pesticidas: a estrutura do solo. Todavia, a maior taxa de lixiviação da atrazina nas colunas preenchidas com amostras do solo sob manejo convencional (PC) 
em relação ao plantio direto, assim como a maior taxa de formação de resíduo-ligado no PD (Tabela 12), embora, como já comentado, estas diferenças tenham sido muito brandas, sugerem o efeito da matéria orgânica na retenção da atrazina. Embora a atrazina seja uma molécula com características de base fraca, sua constante de dissociação $\left(\mathrm{p} K_{\mathrm{a}}\right)$ é da ordem de apenas 1,7 (Montgomery, 1997). Isto, em conjunção com seu valor elevado de coeficiente de partição octanol/ água $\left(\log \mathrm{K}_{\mathrm{OW}}=2,34\right)$ e com os valores de $\mathrm{pH}$ do solo sob os dois sistemas de cultivo, que indicam que as moléculas se encontram desprovidas de carga (Tabela 9), pode explicar a maior tendência de lixiviação no tratamento com menor conteúdo de carbono (Tabelas 9 e 12).

Tabela 12. Balanço de massas observado e previsto pelo modelo "two-site", para ${ }^{14} \mathrm{C}$ atrazina, em colunas preenchidas com amostras de um Latossolo Vermelho Distroférrico sob plantio direto (PD) ou convencional (PC)

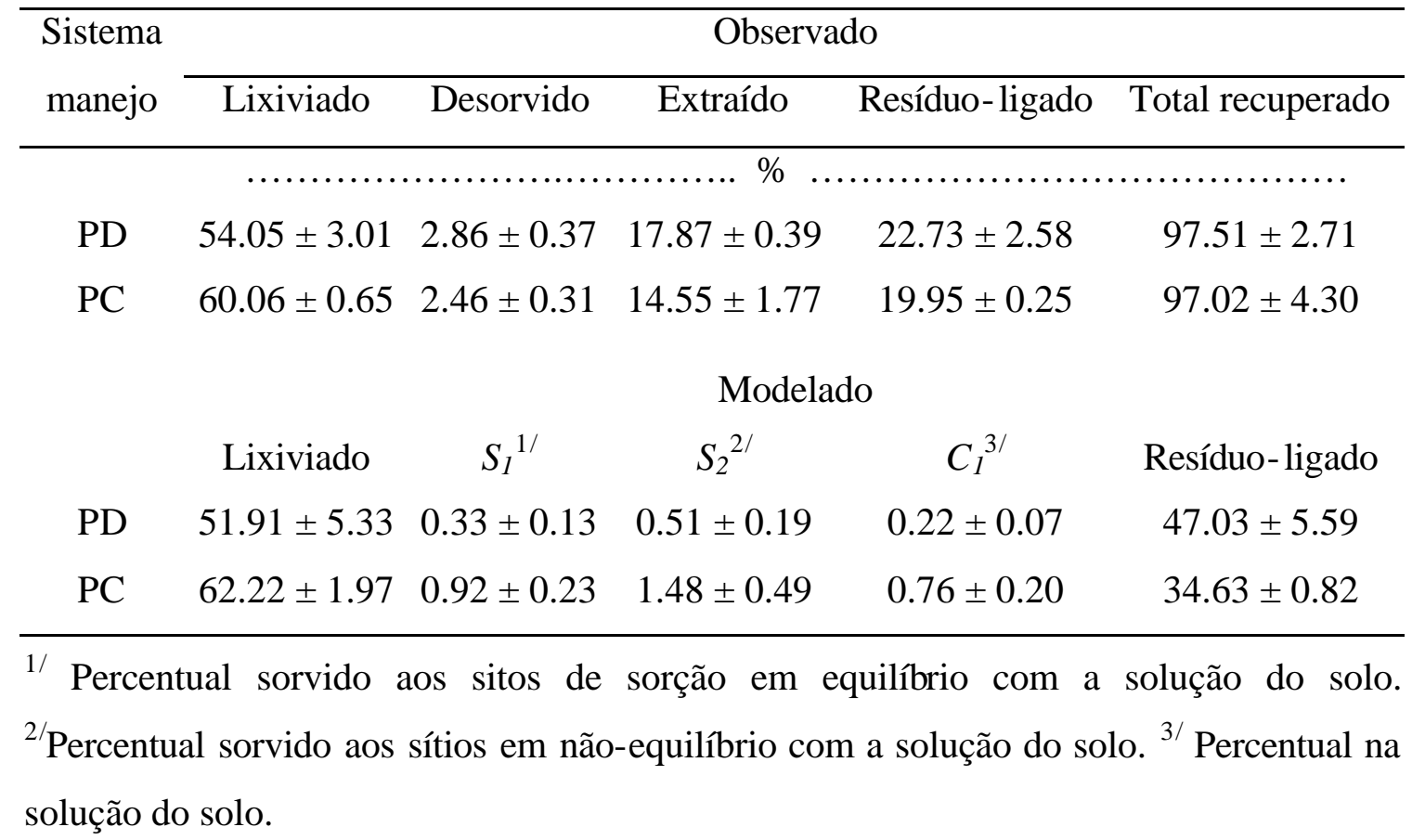


A contribuição do sistema de plantio direto na retenção da atrazina, sob o ponto de vista químico, foi mostrada previamente na literatura (Sadeghi, et al., 1998; Shelton et al., 1998), e foi relacionada aos aspectos quantitativos da matéria orgânica. Sadeghi et al. (1998) mostraram que após 4 anos de adoção do plantio direto, com aplicações anuais de atrazina, a concentração desta molécula na camada superior do perfil $(1,5 \mathrm{~cm}$ de profundidade) foi $50 \%$ superior em relação a observada para o sistema convencional de cultivo. Isto refletiu numa redução acentuada da lixiviação da atrazina no PD, onde a taxa de percolação da molécula, após apenas um ano de implantação do sistema, já foi inferior que na área cultivada sob PC.

O modelo de transporte baseado na equação de convecção-dispersão (CDE), considerando o equilíbrio de sorção e fator de retardação de valor unitário, ajustou-se com sucesso as curvas de lixiviação do $\mathrm{Br}^{-}$(Figura 10). A simetria das curvas mostrou não ter havido regiões estagnadas nas colunas, o que nos permitiu desconsiderar o nãoequilíbrio físico.

A previsão da lixiviação da atrazina (Tabela 12), assim como o ajuste de sua curva de lixiviação (Figura 10), foram realizados também com sucesso quando se utilizou o modelo "two-site", para ambos os sistemas de cultivo. As curvas de lixiviação foram similares para os sistemas de manejo, mostrando uma "chapa" e uma "cauda", comportamento característico para solutos que reagem com a matriz, mas não apresentam equilíbrio de sorção (Kookana et al., 1993).

A porcentagem de atrazina dessorvida foi de somente 2,86 e 2,46\% para PD e PC, respectivamente (Tabela 12). A utilização da solução de $\mathrm{CaCb} 0,01 \mathrm{~mol} \mathrm{~L}^{-1}$ para dessorção da atrazina, confere a essa fração importância particular, pois essa solução apresenta força iônica semelhante à da solução do solo, em condições originais de campo. Desta forma, a fração dessorvida pode ser considerada, embora que grosseiramente, a fração trocável da atrazina no solo, isto é, a fase que apresenta sorção "reversível". 

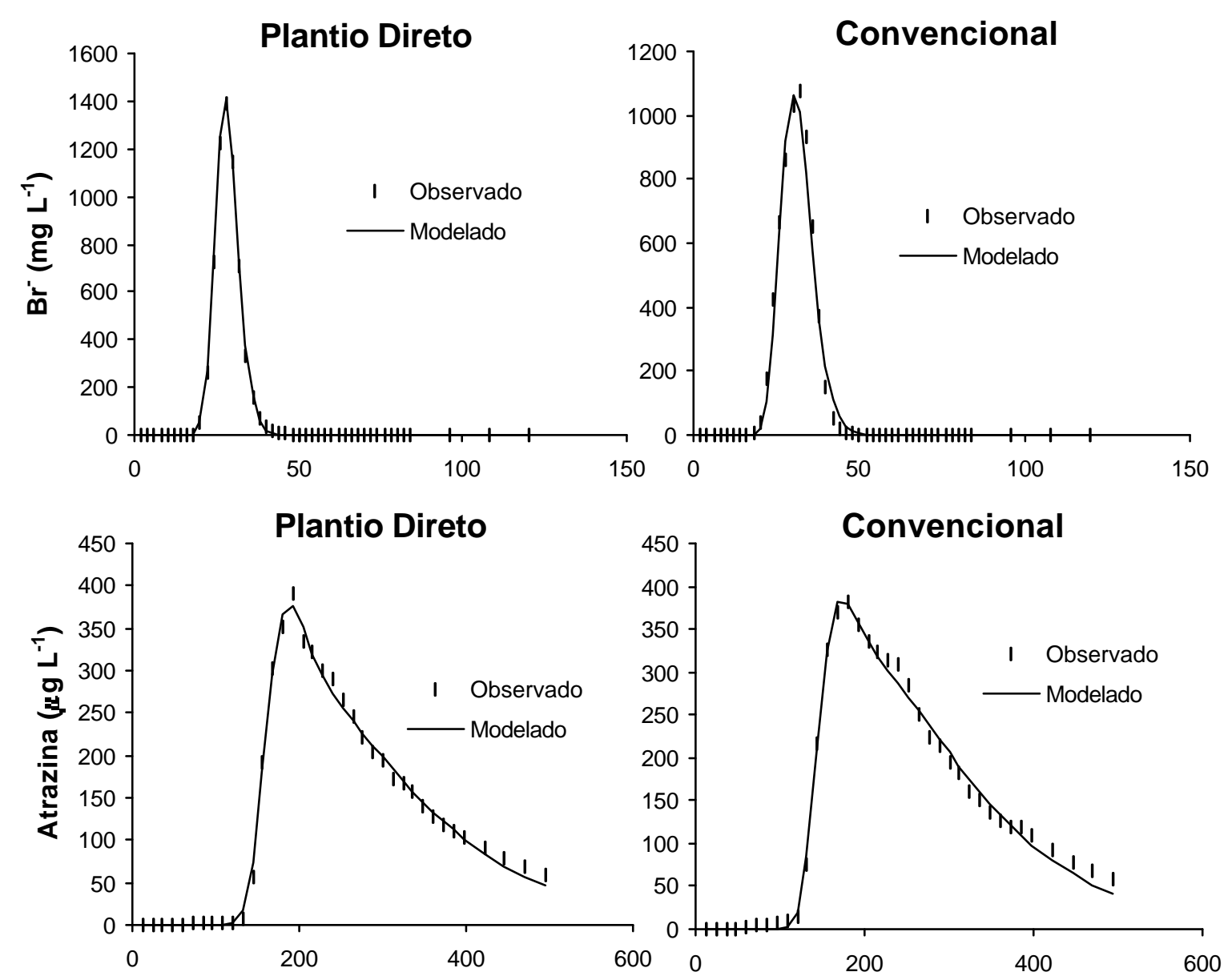

\section{Tempo (h)}

Figura 10. Curvas de lixiviação observada e modelada para $\mathrm{Br}^{-}$e atrazina, em colunas preenchidas com amostras de um Latossolo Vermelho Distroférrico sob plantio direto ou convencional

Quando utilizada a acetonitrila como solvente extrator, observou-se valores para a extração da atrazina da ordem de 17,87 \%, para o PD, e 14,55 \%, para o PC, (Tabela 12). Esses maiores valores, quando comparados às porcentagens de dessorção, podem ser explicados pela maior solubilidade do herbicida e seus metabólitos neste solvente do que em água (Montgo mery, 1997). 
Através da modelagem, foi possível verificar a sorção da atrazina em sítios em equilíbrio $\left(S_{1}\right)$ e não-equilíbrio $\left(S_{2}\right)$ com a solução (Tabela 12). Como esperado, pelo formato da "cauda" das curvas de lixiviação, verificoutse a maior proporção de atrazina sorvida aos sítios em não-equilíbrio em relação aos em equilíbrio, para ambos os sistemas de cultivo (Tabela 12). Isto pode ser explicado tanto por características da molécula (por exemplo, a baixa solubilidade em água) como pela maior proporção de sítios em não-equilíbrio em relação aos sítios em equilíbrio com a solução $(f<1$, Tabela 13).

Quando somados os valores percentuais de atrazina sorvida aos sítios em equilíbrio, em não-equilíbrio e presente na solução do solo, previstos pela modelagem, observaram-se valores muito semelhantes aos da fração dessorvida (Tabela 12). Partindo-se do princípio que o modelo considera a fração sorvida aos sítios em nãoequilíbrio como uma fração intermediária entre a sorvida aos sítios em equilíbrio e a sorvida irreversivelmente (fração resíduo-ligado), porém ainda reversível, esses resultados tornam-se condizentes e apresentam-se como mais um ponto positivo do modelo o "two-site". 
Tabela 13. Parâmetros de transporte previstos para o deslocamento do $\mathrm{Br}^{-}$e atrazina, em colunas preenchidas com amostras de um Latossolo Vermelho Distroférrico sob plantio direto (PD) ou convencional (PC)

\begin{tabular}{|c|c|c|c|c|c|c|c|c|c|}
\hline \multirow{2}{*}{$\begin{array}{l}\text { Sistema } \\
\text { Manejo }\end{array}$} & \multicolumn{3}{|c|}{ ECD (equilíbrio) ${ }^{1 /}$} & \multicolumn{5}{|c|}{ ECD ("Two-site" - não-equilíbrio) $)^{2 /}$} & \multirow[b]{2}{*}{$\mathrm{R}^{2}$} \\
\hline & $v^{3 /}$ & $D^{4 /}$ & $\mathrm{R}^{2}$ & $R^{5 \prime}$ & $K_{d}^{6 /}$ & $f^{\prime \prime}$ & $1 / \alpha^{8 /}$ & $1 / \mu_{4}{ }^{9 /}$ & \\
\hline & $\mathrm{mm} \mathrm{h}^{-1}$ & $\mathrm{~mm}^{2} \mathrm{~h}^{-1}$ & & & $\mathrm{~L} \mathrm{~kg}^{-1}$ & & & & \\
\hline PD & $7,60 \pm 1,6$ & $14,2 \pm 3,7$ & $0,98 * *$ & $9,65 \pm 0,52$ & $3,6 \pm 0,4$ & $0,58 \pm 0,01$ & $52,6 \pm 15,2$ & $54,4 \pm 7,2$ & $0,99 * *$ \\
\hline $\mathrm{PC}$ & $7,05 \pm 0,3$ & $15,2 \pm 2,0$ & $0,99 * *$ & $8,65 \pm 0,59$ & $3,1 \pm 0,4$ & $0,56 \pm 0,08$ & $33,9 \pm 5.0$ & $58,8 \pm 11,8$ & $0,99 * *$ \\
\hline
\end{tabular}

${ }^{1 /}$ Modelo de transporte baseado na equação de convecção-dispersão (ECD) para solutos que apresentam equilíbrio de sorção $\left(\mathrm{Br}^{-}\right) .{ }^{2 /}$ Modelo de transporte baseado na ECD para solutos que não apresentam equilíbrio de sorção (atrazina). ${ }^{3 /}$ Velocidade da água nos poros. ${ }^{4 /}$ Coeficiente de dispersão aparente. ${ }^{5 /}$ Fator de retardação. ${ }^{6 /}$ Coeficiente de partição. ${ }^{7 /}$ Relação entre os sítios de sorção em equilíbrio e não-equilíbrio com a solução do solo. ${ }^{8 /}$ Meia-vida de dessorção. ${ }^{9 /}$ Meiavida para a formação de resíduo-ligado. 
De acordo com a previsão realizada através da modelagem matemática, os percentuais de formação de resíduo-ligado nas colunas foram superiores aos valores determinados (Tabela 12). Para o PD, os valores modelados foram aproximadamente o dobro dos valores percentuais observados. Para o PC, a fração resíduo-ligado modelada foi aproximadamente 1,7 vez superior a determinada (Tabela 12). Entretanto, os valores modelados, para ambos os sistemas de manejo, foram bem parecidos com a soma das frações observadas para resíduo-ligado e extração (Tabela 12). Isto também sugere um bom ajuste do modelo, pois a definição desta fração resíduo-ligado, embora bastante utilizada, não é bem estabelecida e ainda encontra-se em discussão. A última tentativa de definição, a qual tem sido, de certa forma, a aceita pela comunidade científica, foi publicada por Führ et al. (1998): "Resíduo-ligado representa compostos no solo, planta ou animal, os quais persistem na matriz, na forma original ou metabolizada(s) após extração. Para tal, o método de extração não deve alterar substancialmente a molécula ou a matriz". Desta forma, neste trabalho não existe como assegurar se a fração extraída com acetonitrila realmente representa uma fração sorvida que pode apresentar dessorção em condições de campo, em escala de tempo, ou se este solvente extrai também o que, para plantas e microrganismos, em condições de campo, apresenta sorção irreversível.

A distribuição da fração resíduo-ligado nas partículas de solo, previamente definidas como fase sedimento, microagregado e coloidal, encontra-se na Figura 11. Embora a maior parte da radioatividade não extraída encontrou-se na fase sedimento, a fase coloidal mostrou-se de fundamental importância para a formação da fração resíduoligado, dada a sua baixa massa em comparação às outras duas fases. A lixiviação de moléculas ligadas às frações coloidais móveis, em particular a lixiviação de moléculas hidrofóbicas associadas ao carbono orgânico dissolvido (COD), tem despertado o interesse de muitos cientistas (Magee et al., 1991; Lanfrace et al., 1994; Vereecken et al., 2001). Por exemplo, Magee et al. (1991) verificaram, em experimentos de coluna com solo arenoso, valores de fator de retardação para CDO de grandeza semelhante a dos obtidos para a ${ }^{3} \mathrm{H}^{1} \mathrm{HO}$, molécula usada como traçador. Mais interessante, os autores 
observaram um decréscimo no valor $R$, quando o tratamento foi a associação CDOfenantrona.
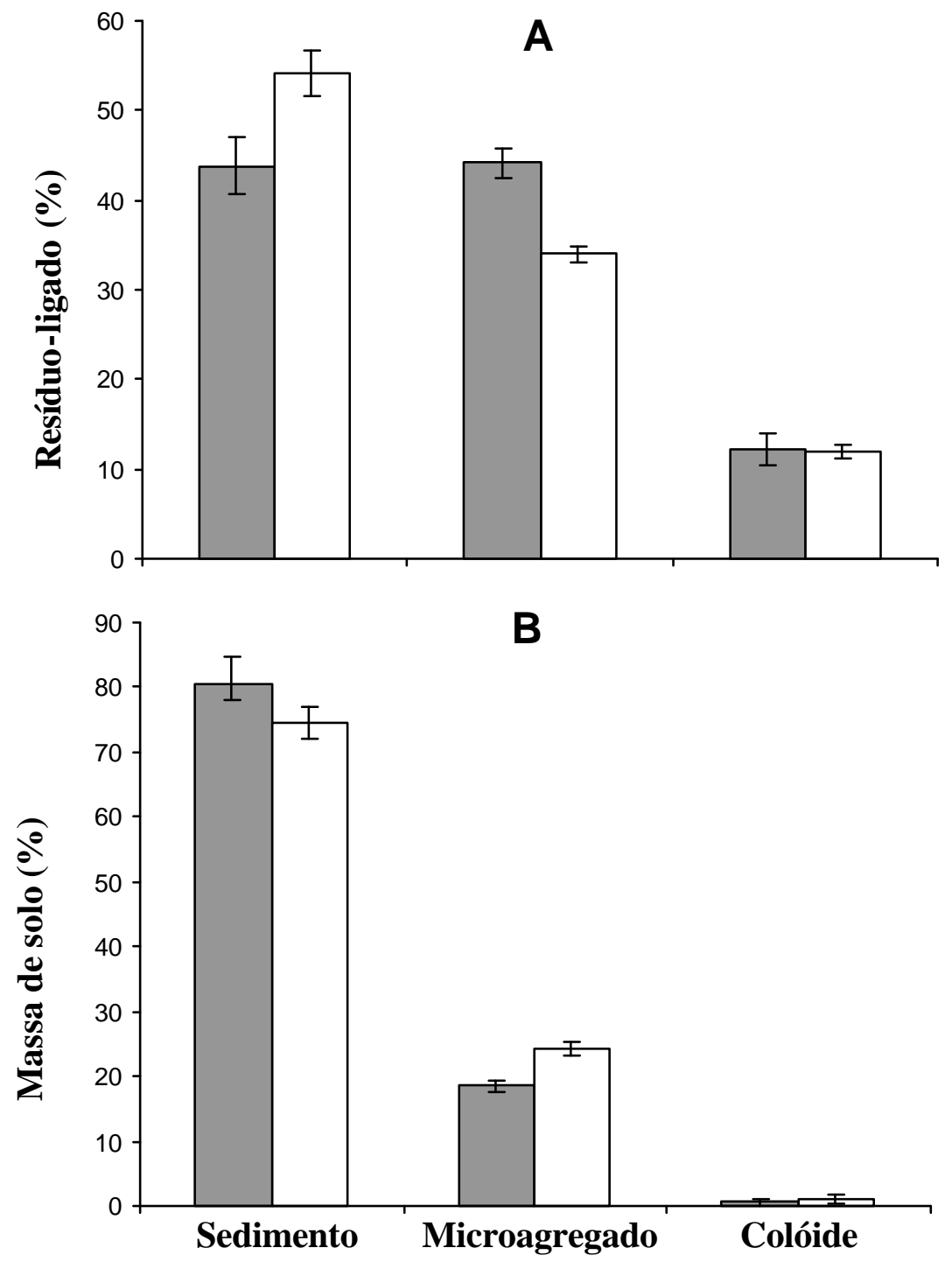

\section{Plantio Direto $\quad \square$ Conventional}

Figura 11. Distribuição da fração resíduo-ligado (A) e massa relativa de solo (B) nas frações sedimento, microagregado e coloidal, após estudo de lixiviação em colunas preenchidas com amostras de um Latossolo Vermelho Distroférrico sob plantio direto ou convencional. As linhas verticais representam o desvio padrão da média 
O fator de retardação $(R)$ é um parâmetro que exprime o efeito da sorção na lixiviação. Para solutos que não apresentam sorção, como o íon $\mathrm{Br}^{-}$, o fator de retardo é de valor unitário. Quanto maior for $R$, maior será a sorção e, conseqüentemente, menor a lixiviação do soluto.

O fatores de retardação e os coeficientes de partição $\left(K_{\mathrm{d}}\right)$ da atrazina (Tabela 13), calculados pelo modelo para os dois sistemas de cultivo, estão de acordo com a literatura (Meyer-Windel et al., 1999; Mersie et al., 1999) e sugerem um potencial de lixiviação médio para esse herbicida, sob estas condições. O adjetivo "médio", empregado na sentença anterior, não se refere a uma classificação propriamente dita, mas sim a uma classificação subjetiva, com base no comportamento de moléculas que são imóveis no solo (por exemplo, o glifosato - Montgomery, 1997) e moléculas extremamente móveis (por exemplo, o picloram - Montgomery, 1997). A referência à atrazina como molécula de mobilidade média no solo, também foi feita por Rodrigues \& Almeida (1995).

A grande maioria dos estudos de lixiviação em colunas desconsidera a transformação, ou degradação, do soluto durante o processo (Ma \& Selim, 1996; Biegel \& Di Pietro, 1999; Mersie et al., 1999). Para moléculas que apresentam taxas consideráveis de metabolização, a ignorância deste fenômeno nos estudos de lixiviação pode levar a resultados completamente irrelevantes. O parâmetro relacionado a transformação da molécula foi inserido no modelo "two-site/two-region" por van Genuchten \& Wagenet (1989) e, a partir daí, a modelagem das curvas de lixiviação passou a ser melhor ajustada.

A porcentagem de metabolização da atrazina nas soluções percoladas foi muito baixa, para ambos os sistemas de cultivo (Figura 12), permanecendo quase que a totalidade lixiviada na forma original ( $95 \%$ no PD e $93 \%$ no PC). Em decorrência desta baixa transformação, a radioatividade lixiviada foi tratada neste trabalho como atrazina lixiviada. Todavia, embora em baixas concentrações, os metabólitos caracterizados na solução percolada foram a hidroxiatrazina (HA), a desetilatrazina (DEA) e a desisopropilatrazina (DIA) (Figura 12). 


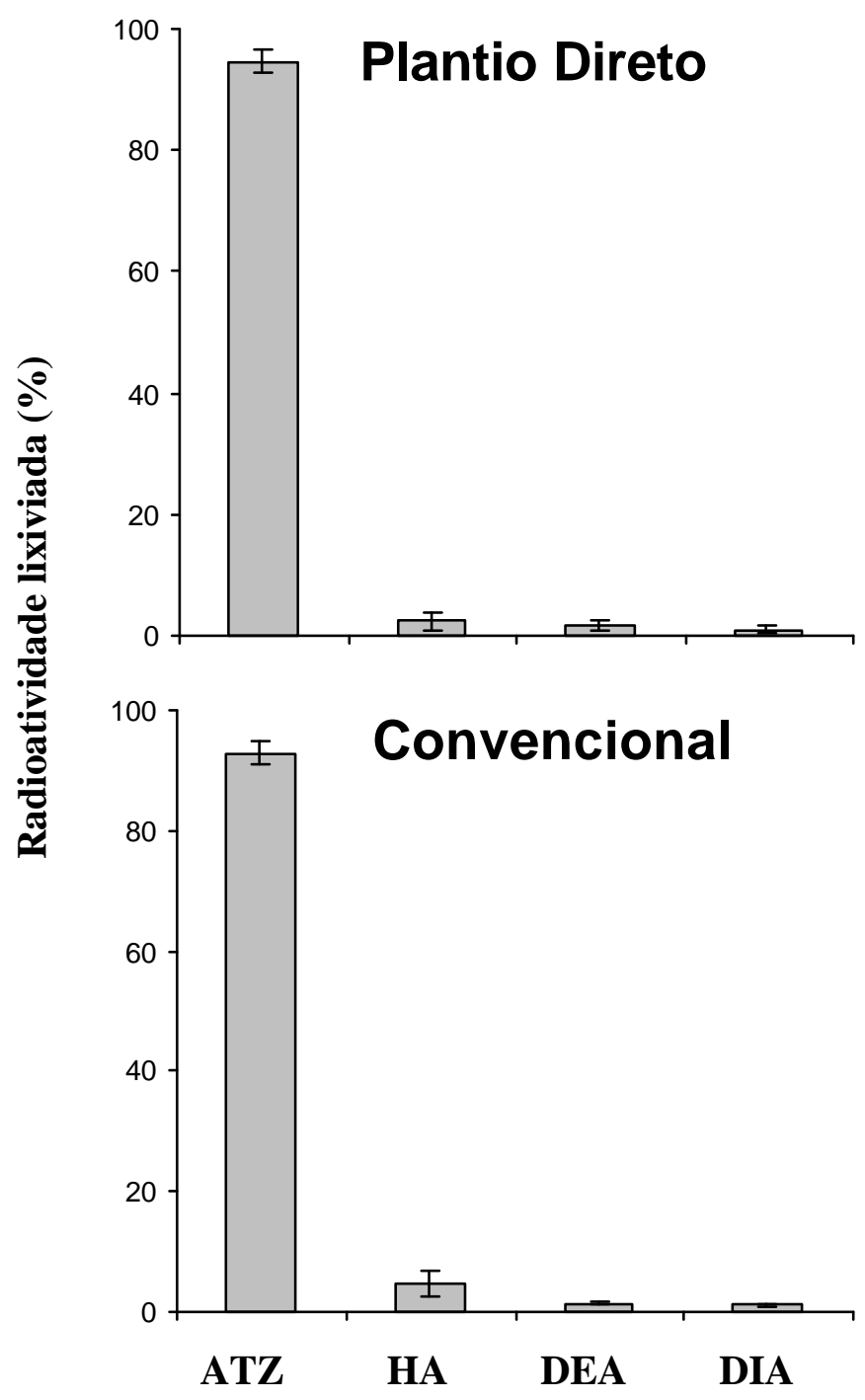

Figura 12. Caracterização da radioatividade lixividada em colunas preenchidas com amostras de um Latossolo Vermelho Distroférrico sob plantio direto ou convencional. $\mathrm{ATZ}=$ Atrazina. $\mathrm{HA}=$ Hidroxiatrazina. $\mathrm{DEA}=$ Desetilatrazina. DIA $=$ Desisopropilatrazina. As linhas verticais correspondem ao desvio padrão da média. 
Para a radioatividade dessorvida, $83,5 \%$ e $76,3 \%$ foi caracterizado como atrazina para PD e PC, respectivamente. Na fração extraída, foi caracterizado como atrazina $86,9 \%$ e $81,8 \%$ da radioatividade presente, respectivamente para PD e PC (Figura 13). A diferença observada entre a porcentagem de metabolização na solução lixiviada e nas frações dessorvida e extraída, sugere maior mobilidade para atrazina em relação a seus metabólitos.
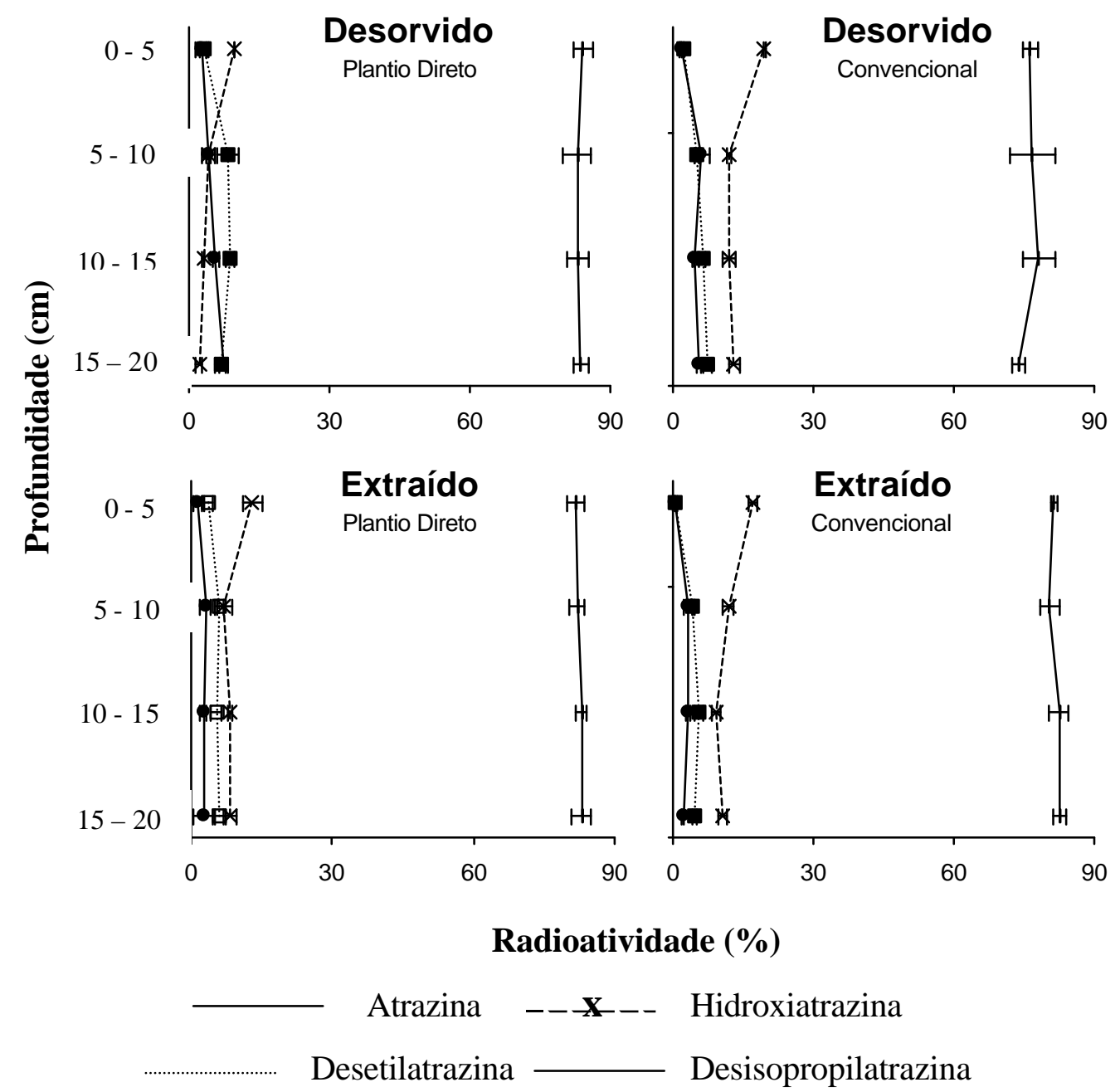

Figura 13. Caracterização da radioatividade dessorvida e extraída, a diferentes profundidades, de colunas preenchidas com amostras de um Latossolo Vermelho Distroférrico sob plantio direto ou convencional. As linhas horizontais correspondem ao desvio padrão da média. 
Vários autores têm mostrado a maior retenção do metabólito HA em relação a atrazina e aos outros metabólitos, DEA e DIA (Clay \& Koskinen, 1990; Brower et al., 1990; Mersie \& Seybold, 1996; Lerch et al., 1999), o que tem sido atribuído à menor solubilidade em água da HA e a sua maior estabilidade termodinâmica (Erickson \& Lee, 1989; Lerch et al., 1999). Isto também foi observado neste trabalho. Tanto na fração dessorvida como na extraída, verificou-se a maior concentração de HA em relação aos outros dois metabólitos na camada superficial das colunas $(0$ a $5 \mathrm{~cm})$, sendo que para as outras camadas a concentração de DEA e DIA foi superior a de HA, para ambos os sistemas de cultivo (Figura 13).

O metabólito HA, mais importante metabólito da atrazina no solo (Lerch et al., 1999), é formado, principalmente, através da hidrólise química, reação que é catalizada pelos processos de sorção e baixos valores de $\mathrm{pH}$ (Lerch et al., 1999). De fato, o solo estudado nesta pesquisa, sob ambos os sistemas de cultivo, apresentou considerável conteúdo de carbono orgânico, o que poderia ter contribuído para a maior metabolização (induzida pela sorção) da atrazina em HA.

Outro aspecto importante relacionado à maior taxa de sorção da HA em relação a atrazina, diz respeito à possibilidade da radioatividade não extraída (fração resíduoligado) ter sido constituída, em parte, por HA. Martin-Neto et al. (2001) estudaram mecanismos de sorção da atrazina em substancias húmicas e observaram a transferência de prótons entre a molécula e a fração orgânica do solo. Segundo os autores, isso poderia promover o deslocamento do átomo de $\mathrm{Cl}$ da molécula da atrazina, transformando-a em HA sorvida.

A radioatividade remanescente, observada nas colunas após a extração (considerada como fração resíduo-ligado), foi maior nas camadas 0 - 5 e 15 - $20 \mathrm{~cm}$ do que nas camadas intermediárias, para ambos os sistemas de cultivo (Figuras 14A e B). A estratificação dos resíduos-ligados na superfície da coluna pode ser explicada pelo efeito do ponto de aplicação da molécula, pelos baixos valores de meia-vida devido a sorção irreversível (l/ $\mu_{1}$, Tabela 13) e pela a velocidade da água nos poros (v) empregada (Tabela 10). A conjunção destes três fatores denota à sorção na camada superficial, um 
maior tempo de contato entre o soluto e a superfície coloidal, quando comparado as outras camadas.

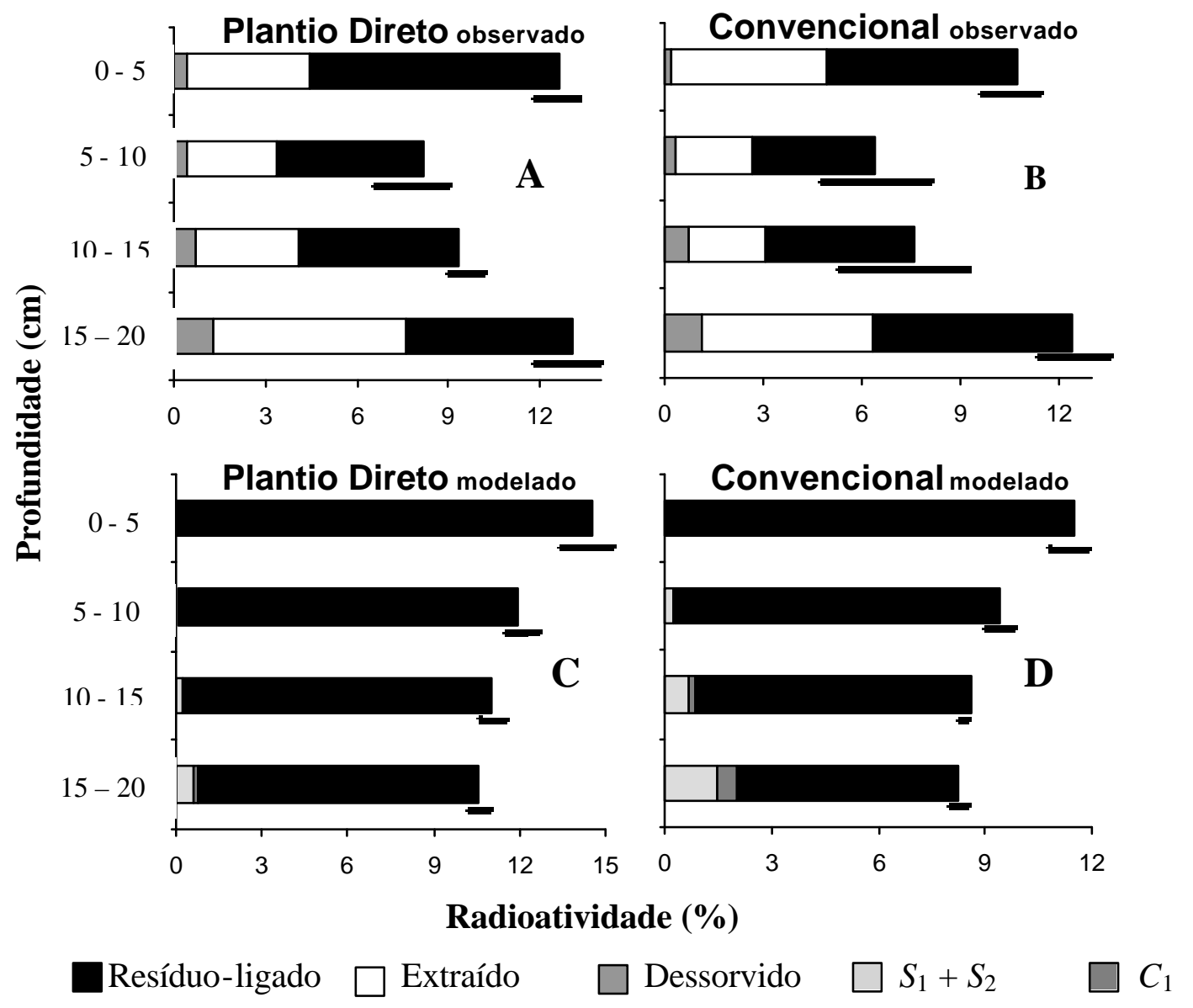

Figura 14. Distribuição modelada e observada da radioatividade residente em colunas preenchidas com amostras de um Latossolo Vermelho Distroférrico sob plantio direto ou convencional. $S_{1}=$ Sovido nos sítios em equilíbrio com a solução do solo. $S_{2}=$ Sorvido nos sítios em não-equilíbrio. $C_{1}=$ Concentração na solução do solo. As linhas horizontais correspondem ao desvio padrão da média para a radioatividade total residente. 
A diferença da distribuição da radioatividade residente nas colunas entre os dados observados e modelados, pode ser explicada pelo fato do modelo assumir que a lixiviação foi conduzida até que nenhuma radioatividade fosse observada na solução percolada, o que não foi o procedido.

Outro aspecto de relevância foi que, em contraste com os dados observados, o modelo considerou a maior parte a radioatividade residente nas colunas, após a lixiviação, como resíduo-ligado (Figuras 14C e D). Partindo-se do princípio que o conceito de resíduo-ligado ainda não é consolidado e bem definido, e que a fração extraída do herbicida, em condições reais de campo, pode ser uma fração sorvida irreversivelmente, a maior previsão para a formação de resíduo-ligado no modelo não pode ser considerada como um erro primário, mas sim uma questão de divergência de conceitos.

\subsubsection{Sorção e dessorção}

As percentagens de atrazina sorvida e dessorvida, coeficientes de partição $\left(K_{\mathrm{d}}\right)$ e parâmetros de Freundlich para sorção e dessorção do herbicida foram de magnitude similar no PD e PC (Tabela 14).

O percentual de atrazina sorvido em ambos os sistemas de cultivo foi de aproximadamente $43 \%$ e está de acordo com os baixos valores de $K_{\mathrm{d}}$ e $K_{\mathrm{f}}$ sor (Tabela 14). Os valores do parâmetro $N$, para sorção, foram de 0,84 e 0,85 para PD e PC, respectivamente, mostrando isotermas de sorção não lineares para a atrazina, nas concentrações empregadas. A magnitude destes valores está de acordo com a literatura (Clay \& Koskinen, 1990; Mersie \& Seybold, 1996; Moreau \& Mouvet, 1997; Mersie et al., 1999) e sugere um grau de sorção intermediário para a atrazina, quando comparada com moléculas altamente sorvidas (por exemplo, o glifosato e os organoclorados - Prata et al., 2000b; Roberts \& Hudson, 1999, respectivamente) ou de sorção reduzida (por exemplo, o picloram e o aldicarb - Roberts et al., 1998; Roberts \& Hudson, 1999). 
Tabela 14. Sorção, dessorção e parâmetros de Freundlich para sorção e dessorção de atrazina em um Latossolo Vermelho Distroférrico sob plantio direto ou convencional

\begin{tabular}{|c|c|c|c|c|c|c|c|c|c|}
\hline \multirow{2}{*}{$\begin{array}{l}\text { Sistema de } \\
\text { Manejo }\end{array}$} & \multirow[t]{2}{*}{$\mathrm{S}^{1 /}$} & \multirow[t]{2}{*}{$\mathrm{D}^{2 \prime}$} & \multirow[t]{2}{*}{$K_{\mathrm{d}}^{3 /}$} & \multicolumn{6}{|c|}{ Parâmetros de Freundlich } \\
\hline & & & & $K_{f \text { sor }}^{4 /}$ & $K_{f \mathrm{des}}^{5 /}$ & $N_{\text {sor }}^{6 /}$ & $N_{\text {des }}{ }^{7 /}$ & $\mathrm{R}_{\text {sor }}^{2}$ & $\mathrm{R}_{\text {des }}^{2}$ \\
\hline & $\ldots \% \ldots$ & $\ldots \% \ldots$ & $\ldots \mathrm{L} \mathrm{kg}^{-1} \ldots$ & $\ldots . .\left(\mathrm{mg} \mathrm{kg}^{-1}\right)$ & $\left.\mathrm{mg}^{-1}\right)^{\mathrm{N}}$. & & & & \\
\hline Plantio Direto & $43,4 \pm 4,38$ & $91,6 \pm 1,6$ & $3,88 \pm 0,08$ & $2,97 \pm 0,04$ & $3,27 \pm 0,10$ & $0,85 \pm 0,01$ & $0,82 \pm 0,05$ & 0,99 & 0,99 \\
\hline Convencional & $42,5 \pm 4,50$ & $91,4 \pm 1,9$ & $3,73 \pm 0,10$ & $3,10 \pm 0,03$ & $3,19 \pm 0,23$ & $0,84 \pm 0,02$ & $0,80 \pm 0,07$ & 0,99 & 0,99 \\
\hline
\end{tabular}

${ }^{1 /}$ Atrazina sorvida. ${ }^{2 /}$ Atrazina dessorvida. ${ }^{3 /}$ Coeficiente de sorção linear. ${ }^{4 /}$ Coeficiente de Freundlich para sorção. ${ }^{5 /}$ Coeficiente de Freundlich para dessorção. ${ }^{6 /}$ Grau de linearidade da isoterma de sorção. ${ }^{7 /}$ Grau de linearidade da isoterma de dessorção. 
Os valores de $K_{\mathrm{d}}$ neste experimento $\left(3,8\right.$ e $3,7 \mathrm{~L} \mathrm{~kg}^{-1}$ para PD e PC, respectivamente) foram similares àqueles obtidos através da modelagem dos dados de deslocamento miscível (Tabela 13). Esta similaridade contradiz o trabalho de Vereecken et al. (1999), no qual os resultados de sorção, gerados através de experimentos de coluna e "batch", foram bem discrepantes. Uma crítica severa, dentre outras, aos experimentos de sorção em "batch" refere-se a diferença entre os resultados obtidos por essa técnica e os obtidos nos experimentos de coluna, que são considerados mais acurados.

Ao final do experimento de dessorção, quase a totalidade da concentração de atrazina sorvida (aproximadamente 94 \%) pôde ser dessorvida, em ambos os sistemas de cultivo, como sugerido pelos baixos valores de $K_{\mathrm{f} \text { des }}$ (Tabela 14). Entretanto, mesmo com esta alta taxa de dessorção, o fato de $N_{\text {des }}<N_{\text {sor }}$ indicou ter havido histerese (Tabela 14). Isto significa que a sorção não é completamente reversível e envolve menor transferência de energia que a dessorção (Moreau \& Mouvet, 1997), embora nenhuma explanação conclusiva sobre este fenômeno possa ser encontrada na literatura. A possível causa da histerese pode ter sido os diferentes mecanismos de ligação relacionados à sorção das triazinas à matéria orgânica do solo, como: as ligações de hidrogênio, transferência de prótons, interações hidrofóbicas e difusão física (Choudhry, 1983; Senesi, 1992; Moreau \& Mouvet, 1997; Martin-Neto et al., 2001).

O mais notável contraste entre os resultados obtidos neste experimento e no de deslocamento miscível, está relacionado a dessorção. Enquanto o percentual dessorvido, neste experimento, foi em torno de $94 \%$, para ambos os sistemas de cultivo, no experimento de colunas conseguiu-se apenas $2,86 \%$ e 2,46\%, para PD e PC respectivamente. Embora a solução de $\mathrm{CaCh}$ 0,01 $\mathrm{mol} \mathrm{L}^{-1}$ tenha sido usada na dessorção para os dois casos, o tempo de contato entre o herbicida e o solo foi muito maior no experimento de colunas. Isto poderia ter contribuído com a difusão física da atrazina para o interior das substâncias húmicas e/ou microagregados argilo-húmicos, em maior escala no experimento de colunas. Desta forma, a formação de resíduo-ligado poderia ter sido beneficiada com o tempo, proporcionando um decréscimo na dessorção da atrazina residual no experimento de coluna. Para tanto, se faz necessário assumir que o tempo de 
agitação de equilíbrio de sorção, empregado no experimento "batch", não foi suficiente para a formação da fração resíduo-ligado. Os valores de meia-vida de dessorção (1/ $\alpha$, Tabela 13) foram de magnitude superior ao período de agitação de equilíbrio no "batch", o que associado ao fator profundidade da coluna, também ajuda explicar, em parte, a menor dessorção observada no experimento de colunas. Adicionalmente, Pignatello et al. (1993) mostraram que a simples presença de um fluxo de água nas colunas pode contribuir de forma negativa com o equilíbrio de dessorção, favorecendo a difusão física da molécula para o interior dos microagregados.

\subsection{Conclusões}

A atrazina apresenta potencial de lixiviação no solo, independente do sistema de manejo. Este potencial é dependente da sorção nos sítios em equilíbrio e não-equilíbrio com a solução do solo e, principalmente, da sorção irreversível.

A HA é o principal metabólito da atrazina e apresenta menor lixiviação que a molécula original e os outros metabólitos.

O modelo de transporte que considera o equilíbrio de sorção foi ajustado com sucesso para o deslocamento do $\mathrm{Br}^{-}$, mostrando não ter havido efeito físico no nãoequilíbrio de sorção da atrazina.

O modelo de transporte "two-site" foi ajustado com sucesso aos dados de deslocamento miscível da atrazina para ambos os sistemas de cultivo. Todavia, superestimou a sorção irreversível para a concentração residente na coluna.

O coeficiente de sorção linear $\left(K_{d}\right)$ foi estimado similarmente pelo ajuste do modelo de transporte "two-site" aos dados de deslocamento miscível e pelo método "batch". 


\section{CONCLUSÕES}

A sorção do glifosato é instantânea, extremamente alta e está relacionada, principalmente, a fração mineral do solo, sendo que a matéria orgânica desempenha papel secundário no caso de solos oxídicos. Em solos com baixo conteúdo de óxidos, a matéria orgânica é fundamental na sorção dessa molécula.

O glifosato compete com os fosfatos inorgânicos pelos sítios de sorção. Entretanto, esta competição somente passa a ser quando os níveis de $\mathrm{P}$ no solo são extremamente altos, níveis estes impossíveis de ser atingidos sob condições reais de campo.

O glifosato não pode ser extraído do solo em condições normais de solos agricultáveis, permanecendo na forma de resíduo-ligado.

O sistema de plantio direto pode contribuir ligeiramente para a aceleração da mineralização do glifosato no solo.

A meia-vida do glifosato é baixa e está relacionada principalmente à formação de resíduos-ligados, não apresentando problemas de fitotoxidez para o Panicum maximum.

A atrazina apresenta potencial de lixiviação no solo, independente do sistema de manejo. Este potencial é dependente da sorção nos sítios em equilíbrio e não-equilíbrio com a solução do solo e, principalmente, da sorção irreversível. 
$\mathrm{O}$ modelo de transporte que considera o equilíbrio de sorção foi ajustado com sucesso para o deslocamento do $\mathrm{Br}^{-}$, mostrando não ter havido efeito físico no nãoequilíbrio de sorção da atrazina.

O modelo de transporte "two-site" foi ajustado com sucesso aos dados de deslocamento miscível da atrazina para ambos os sistemas de cultivo. Todavia, superestimou a sorção irreversível para a concentração residente na coluna.

O coeficiente de sorção linear $\left(K_{d}\right)$ foi estimado similarmente pelo ajuste do modelo de transporte "two-site" aos dados de deslocamento miscível e pelo método "batch". 


\section{REFERÊNCIAS BIBLIOGRÁFICAS}

ADDISCOT, T.M.; WAGENET, R.J. Concepts of solute leaching in soils: a review of modeling approaches. Soil Science, v.36, p.411-424, 1985.

ANDREUX, F.; SCHEUNERT, I.; ADRIAN, P.; SCHIAVON, M. The binding of pesticide residues to natural organic matter, their movement, and their bioavailability. In: MANSOUR, M. (Ed.) Fate and prediction of environmental chemicals in soils, plants, and aquatic systems. Florida: Boca Raton, 1993. p.133148.

ARMSTRONG, D.E.; CHESTERS, G. \& HARRIS, R.F. Atrazine hydrolysis in soils. Soil Science Society of America Proceedings, v.31, p.61-66, 1967.

AYENI, A.O.; MAJEK, B.A.; HAMMERSTEDT, J. Rainfall influence on imazethapyr bioactivity in New Jersey soils. Weed Science, v., p. 46:581-586, 1998.

BARRIUSO, E.; HOUOT, S.; SERRA-WITTLING, C. Influence of compost addition to soil on the behaviour of herbicides. Pesticide Science, v.49, p.65-75, 1997.

BARRIUSO, E.; KOSKINEN, W.C. Incorporating nonextractable atrazine residues into soil size fractions as a function of time. Soil Science Society of America Journal, v.60, p. 150-157, 1996. 
BIEGEL, C.; Di PIETRO, L. Transport of triconazole in homogeneous soil columns: Influence of nonequilibrium sorption. Soil Science Society of America Journal, v.63, p.1077-1086, 1999.

BLANCHET, P.F.; St-GEORGE, A. Kinetics of chemical degradation of organophosphorus pesticides. Hydrolysis of chlorpyrifos and chlorpyrifos-methyl in the presence of cooper (II). Pesticide Science, v.13, p.85-91, 1982.

BOUCHARD, D.C.; ENFIELD, C.G. \& PIWONI, M.D. Transport processes involving organic chemicals. In: SAWHNEY, B.L. \& BROWN, B.L., ed. Reactions and movement of organic chemicals in soils. Madison, Soil Science Society of America. 1989. p:349-372.

BRASIL. Ministério do interior. Manual de testes para avaliação da ecotoxicidade de agentes químicos. Brasília: MINTER-Secretaria Especial do Meio Ambiente, 1988.

BRETH, S.A. Pesticides and their effects on soil and water. Madison, Soil Science Society of America. 1966. 150p.

BROUWER, W.W.; BOESTEN, J.J.T.I.; SIEGERS, W.G. Adsoption of transformation products of atrazine by soil. Weed Research, v.30, p.123-128, 1990.

BRUSSEAU, M.L.; RAO, P.S.C. Influence of sorbate structure on nonequilibrium sorption of organic compounds. Environmental Science Technology, v.25, p.15011506, 1991.

BURAUEL, P.; FÜHR, F. Formation and long-term fate of non-extractable residues in outdoor lysimeter studies. Environmental Pollution, v.108, p.45-52, 2000. 
BURKHARD, W.A. \& KUEHL, D.W. n-Octanol/water partition coefficients by reverse phase liquid cromatography/mass spectrometry for eight tetrachlorinated planar molecules. Chemosphere, v.15, p.163-167, 1986.

CAI, Z.; RAMANUJAM, V.M.S.; GROSS, M.L.; MONSON, S.J.; CASSADA, D.A.; SPALDING, R.F. Liquid-solid extraction and fast atom bombardment highresolution mass spectrometry for the determination of hydroxyatrazine in water at low-ppt levels. Analytical Chemistry, v.66, p.4202-4209, 1994.

CAMARGO, O.A.; MONIZ, A.C.; JORGE, J.A.; VALADARES, J.M. Métodos de análise química, mineralógica e física de solos do Instituto Agronômico de Campinas. Campinas: IAC, 1986. 94p. (IAC. Boletim Técnico, 106).

CAMERON, D.A.; KLUTE, A. Convective-dispersive solute transporte with a combined equilibrium and kinetic adsorption model. Water Resource Research, v.19, p.718-724, 1977.

CHEAH, U.B.; KIRKWOOD, R.C.; LUM, K.Y. Adsorption, desorption and mobility of four commonly used pesticides in malaysian agricultural soils. Pesticide Science, v.50, p.53-63, 1997.

CHEAH, U.B.; KIRKWOOD, R.C.; LUM, K.Y. Degradation of four commonly used pesticides in malaysian agricultural soils. Journal of the Agricultural and Food Chemistry, v.46, p.1217-1223, 1998.

CHENG, H.H. Pesticides in the soil environment: Processes, impacts, and modeling. 2 ed. Madison, Soil Science Society of America, 1990. 530p. 
CHIOU, C.T.; PETERS, P.E.; FREED, V.H. A physical concept of soil-water equilibrium for nonionic organic compounds. Science, v.4420, p.831-832, 1979.

CHOUDHRY, G.G. Humic substances: Sorptive interactions with environmental chemicals. Toxicology Environmental Chemistry, v.6, p.127-171, 1983.

CLAY, S.A.; KOSKINEN, W.C. Adsorption and desorption of atrazine, hidroxyatrazine, and s-glutathione atrazine on two soils. Weed Science, v.38, p.262-266, 1990.

CONNOLLY, R.D.; KENNEDY, I.R.; SILBURN, D.M.; SIMPSON, B.W.; FREEBAIM, D.M. Simulating endosulfan transport in runoff from cotton fields in Australia with the GLEAMS model. Journal of Environmental Quality, v.30, p.702-703, 2001.

CONCEIÇÃO, M.Z. Segurança na aplicação de herbicidas. In: CONGRESSO BRASILEIRO DA CIÊNCIA DAS PLANTAS DANINHAS, 23, Foz do Iguaçu, 2000. Anais. Foz do Iguaçu. Sociedade Brasileira da Ciência das plantas daninhas, 2000. p:46-48.

COSTA, M.A. Biodegradação de ${ }^{14} \mathrm{C}$-ametrina em Areia Quartzosa com adição de palha de cana e solo rizosférico. Piracicaba, 1997. 107p. Dissertação (Mestrado) - Centro de Energia Nuclear na Agricultura, Universidade de São Paulo.

COX, C. Chlorothalonyl. Journal of Pesticide Reforms, v.17, p.14-20, 1997. 
DAI, J.Y.; JIN, L.J.; WANG, L.S.; ZANG, Z. Determination and estimation of water solubilities and octanol/water partition coefficients for derivates of benzanilides. Chemosphere, v.37, p.1419-1426, 1998.

DAY, P.R. Particle fractionation and particle size analysis. In: BLACK, C.A. Ed. Methods of Soil Analysis. ASA Agronomy Series, n.9. American Society of Agronomy, Madison 1965. p.545-567.

DEC, C.; BOLLAG, J.M. Dehalogenation of chlorinated phenols during oxidative coupling. Environmental Science Technology, v.28, p.448,490, 1994.

DERPSCH, R. Expansão mundial do plantio direto, ano 2000. Revista plantio direto virtual - www.plantiodireto.com.br. Feveriro/2002.

DEUBER, R. Ciência das plantas daninhas. Fundamentos. Jaboticabal: FUNEP. 1992. $431 \mathrm{p}$.

EBERBACH, P. Applying non-steady-state comparmental analysis to investigate the simultaneous degradation of soluble and sorbed glyphosate [n(phosphonomethyl)glycine] in four soils. Pesticide Science, v.52, p.229-240, 1998.

EIJSACKERS, H. Effects of glyphosate on the soil fauna. In: GROSSBARD, E.; ATKINSON, D., ed. The herbicide glyphosate. London, British Library, 1985. 490p.

ENFIELD, C.G. Chemical transport facilitated by multiphase flow systems. Water Science Technology, v.17, p.1-12, 1985. 
ENFIELD, C.G.; BENGTSSON, G. Macromolecule transport of hydrophobic contaminants in aqueous environments. Ground Water, v.26, p.64-70, 1988.

ENFIELD, C.G.; YATES, S.R. Organic Chemical transport to groundwater. In: CHENG, H.H.. ed. Pesticides in the soil environment: Processes, impacts, and modeling. 2 ed. Madison, Soil Science Society of America, 1990. p.271-302.

ERICKSON, L.E.; LEE, K.H. Degradation of atrazine and related s-triazines. Critical Review of Environmental Control, v.19, p.1-14, 1989.

FARMER, W.J.; AOCHI, Y. Picloran sorption by soils. Soil Science Society of America Proceedings, v.38, p.418-423, 1974.

FAY, E.F.; SILVA, C.M.M.S.; MELO, I.S. Degradação abiótica de xenobióticos. In: MELO, I.S.; AZEVEDO, J.L. (Ed.) Microbiologia ambiental. Jaguariuna: EMBRAPA, CNPMA, 1997, p.125-140.

FOLONI, L.L. Impacto ambiental do uso de herbicidas. In: CONGRESSO BRASILEIRO DA CIÊNCIA DAS PLANTAS DANINHAS, 23, Foz do Iguaçu, 2000. Anais. Foz do Iguaçu, Sociedade Brasileira da Ciência das plantas daninhas, 2000. p:49-91.

FRANZ, J.E. Discovery, development and chemistry of glyphosate. In: GROSSBARD, E.; ATKINSON, D. (Ed.). The herbicide glyphosate: Britash Library, 1986. p.3-17.

FREITAS, J.R.; NASCIMENTO FILHO, V.; VOSE, P.B.; RUSCHEL, A.P. Estimativa da atividade da microflora heterotrófica do solo TRE usando respirometria com glicose- ${ }^{14}$ C. Energia Nuclear e Agricultura, v.1, p.123-130, 1979. 
FÜHR, F. Non-extractable pesticides residues in soil. In: GREENHALG, R.; ROBERTS, T.R. Pesticide Science and Biotechnology. Oxford: International Union of Pure and Applied Chemistry, 1987. p.381-389.

FÜHR, F.; OPHOFF, H.; BURAUEL, P.; WANNER, U.; HAIDER, K. Modification of the definition of bound residues. In: FÚHR, F.; OPHOFF, H. Pesticide bound residues in soil. Wiley-VCH, Weinheim, Germany. 1998. p:175-176.

GERRITSE, R.G.; BELTRAN, J.; HERNANDEZ, F. Adsorption of atrazine, simazine and glyphosate in soils of the Gnangara Mound, Western Australia. Australian Journal of Soil Research, v.34, p.599-607,1996.

GAMBLE, D.S.; BRUCCOLERI, A.G.LINDSAY, E.; LANGFORD, C.H.; LEYS, G.A. Chlorothalonyl in a quartz sand soil: Speciation and kinetics. Environmental Science and Technology, v.34, p.120-124, 2000.

GEVAO, B.; SEMPLE, K.T.; JONES, K.C. Bound pesticide residues in soil: a review. Environmental Pollution, v.108, p. 3-14, 2000.

GLASS, R.L. Adsorption of glyphosate by soils and clay minerals. Journal of the Agricultural and Food Chemistry, v.35, p.497-500, 1987.

GLOTFELTY, D.E.; SCHOMBURG, C.J. Volatilization of pesticides. In: SAWHNEY, B.L.; BROWN, B.L., ed., Reactions and movement of organic chemicals in soils. Madison, Soil Science Society of America. 1989, p.181-207.

GOELLNER, C. Ecotoxicologia e toxicologia do herbicida paraquat. Zêneca, São Paulo, 1995. 104p. 
GONZALEZ, J.; UKRAINCZYK, L. Transport of nicosulfuron in soil columns. Journal of Environmental Quality, v.28, p.101-107, 1999.

GOSWANI, K.P.; GREEN, R.E. Microbial degradation of the herbicide atrazine and its 2-hydroxy analog in submerged soils. Environmental Science and Technology, v.5, n.5, p.426-429, 1971.

GREENHALGH, R.; DHAWAN, K.L.; WEINBERGER, P. Hydrolysis of fenitrothion in model and natural aquatic systems. Journal of Agricultural and Food Chemistry, v.28, p.102-105, 1980.

GROSSBARD, E.; ATKINSON, D. Preface. In: GROSSBARD, E.; ATKINSON, D. (Ed.). The herbicide glyphosate: Britash Library, 1986. p.1.

GROVER, R. Mobility of dicamba, picloram e 2,4-D in soil columns. Weed Science, v.25, p.159-162, 1977.

GUENZI, W.D. Pesticides in soil and water. Madison, Soil Science Society of America, 1974. 562p.

GUO, L.; WAGENET, R.J. Evaluation of alachlor degradation under transport conditions. Soil Science Society of America Journal, v.63, p.443-449, 1999.

GUSTAFSON, D.I. Groundwater ubiquity score: a simple method for assessing pesticide leachability. Environmental Toxicological Chemistry, v.8, p.339-357, 1989. 
HANCE, R.J. Adsorption of glyphosate by soils. Pesticide Science, v.7, p.363-366, 1976.

HANEY, R.L.; SENSEMAN, S.A.; HONS, F.M.; ZUBERER, D.A. Effect of glyphosate on soil microbial activity and biomass. Weed Science, v. 48, p.89-93, 2000.

HART, M.R.; BROOKES, P.C. Soil microbial biomass and mineralization of soil organic matter after 19 years of cumulative field applications of pesticides. Soil Biology and Biochemistry, v.28, p.1641-1649, 1996.

HILL, B.D.; MILLER, J.J.; HARKER, K.N.; BYERS, S.D.; INABAD, D.J.; ZHANG, C. Estimating the relative leaching potential of herbicides in Alberta soils. Water Quality Research Journal of Canada, 35:693-710, 2000.

HORNSBY, A.G.; WAUCHOUPE, R.D.; HERNER, A.E. Pesticide properties in the environment. New York, Springer-Verlag Inc., 1995, 227p.

HUGUE, M.; ERCAG, E.; APAK, R. Kinetic studies on UV-photodegradation of some chlorophenols using $\mathrm{TiO}_{2}$ catalyst. Journal of Environmental and Science Health, v.37, n.3, p.365-383, 2002.

HULSCHER, T.E.M.; van der VELDE, L.E.; BRUGGEMAN, W.A. Temperature dependence of Henry's law constants for selected chlorobenzenes, polychlorinated biphenyls and polycyclic aromatic hydrocarbons. Environmental and Toxicological Chemistry, v.11, p.1595-1603, 1992.

JACKSON, M.L. Soil chemical analysis: advanced course. American Society of Agronomy, Madison, WI, USA. 1969. 894p. 
JONGE, H; JONGE, L.W. Influence of $\mathrm{pH}$ and solution composition on the sorption of glyphosate and prochloraz to a sandy loam soil. Chemosphere, v.39, p.753-763, 1999.

JONGE, H.; JONGE, L.W.; JACOBSEN, O.H. $\left[{ }^{14} \mathrm{C}\right]$ Glyphosate transport in undisturbed topsoil columns. Pesticide Management Science, v.56, p.909-915, 2000.

JONGE, H.; JONGE, L.W.; JACOBSEN, O.H.; YAMAGUSHI, T.; MOLDRUP, P. Glyphosate sorption in soils of different $\mathrm{pH}$ and phosphorus content. Soil Scince, v.166, p.230-238, 2001.

KATAYAMA, A.; ISEMURA, H.; KUWATSUKA, S. Suppression of chlorothalonyl dissipation in soil by repeated applications. Journal of Pesticide Science, v.16, p.233-238, 1991.

KATAYAMA, A.; ITOU, T.; UKAI, T. Ubiquitous capability to substitute chlorine atoms of chorothalonyl in bacteria. Journal of Pesticide Science, v.22, p.12-16, 1997.

KAWAMOTO, K.; URANO, K. Parameters for predicting fate of organochlorine pesticides in the environment (II) Adsorption constant to soil. Chemosphere, v.19, p.1223-1231, 1989.

KHAN, S.U.; BEHKI, R.M. Effects of Pseudomonas species on the release of bound ${ }^{14} \mathrm{C}$ residues from soil treated with $\left[{ }^{14}\right]$ atrazine. Journal of Agricultural and Food Chemistry, v.38, p.2090-2093, 1990. 
KHAN, S.U. Bound (nonextractable) pesticide degradation products in soils. In: SOMASUNDARAM, L.; COATS, J.R. (Ed.) Pesticide transformation products. Fate and significance in the environment. Washington: ACS, 1991. p.108-121.

JUNG-HO, K.; FEAGLEY, S.E. Adsorption and leaching of trifluralin, metolachlor, and metribuzin in a commerce soil. Journal of Environmental Science and Health, v.B33, n.5, p.529-546, 1998.

KONDA, L.N.; PASZTOR, Z. Environmental distribution of acetochlor, atrazine, chlorpyriphos, and propirochlor under field conditions. Journal of Agricultural and Food Chemistry, v.49, p.3858-3863, 2001.

KONTCHOU, C.Y. \& GSCHWIND, N. Mineralization of the herbicide atrazine in soil inoculated with a Pseudomonas strain. Journal of Agricultural and Food Chemistry, v.43, p.2291-2294, 1995.

KOOKANA, R.S.; SCHULLER, R.D.; AYLMORE, L.A.G. Simulation of simazine transport through soil columns using time-dependent sorption data measured under flow conditions. Journal of Contaminant Hydrology, v.14, p.93-115, 1993.

KOSKINEN, W.C.; HARPER, S. The retention process: Mechanisms. In: CHENG, H.H.. ed. Pesticides in the soil environment: Processes, impacts, and modeling. 2 ed. Madison, Soil Science Society of America, 1990. p.51-78

KRZYSKO-LUPICKA, T.; ORLIK, A. The use of glyphosate as the sole source of phosphorus or carbon for the selection of soil-borne fungal strains capable to degrade this herbicide. Chemosphere, v.34, p.2601-2605, 1997. 
LAFRANCE, P.; MARINEAU, L.; PERREAULT, L.; VILLENUEVE, J.P. Effect of natural dissolved organic matter found in groundwater on soil adsorption and transport of pentachlorophenol. Environmental Science and Technology, v.28, p.2314-2320, 1994.

LAGALY, G.; SCHULZ, O. \& ZIMEHL, R. Dispersionen und emulsionen: eine einführung in die kolloidik feinverteilter stoffe einschliesslich der tonminerale. Darmstadt: Steinkopf, 1997. 543p.

LANGENBACH, T.; SCHROLL, R.; PAIM, S. Fate and distribution of ${ }^{14} \mathrm{C}$-atrazine in tropical soils. Chemosphere, v.40, p.449-455, 2000.

LAVORENTI, A. Comportamento de herbicidas no meio ambiente. In: WORKSHOP SOBRE BIODEGRADAÇÃO. Campinas, 1996. Anais. Jaguariuna: EMBRAPA, CNPMA, 1996. p:81-115.

LAVORENTI, A. Identificação de perigos de resíduos ligados de pesticidas em substâncias húmicas. In: ENCONTRO BRASILEIRO DE SUBSTÂNCIAS HÚMICAS, 2, São Carlos, 1997. Anais. São Carlos:EMBRAPA,1997. p.66-71.

LAVORENTI, A. Comportamento dos herbicidas no solo. In: ENCONTRO BRASILEIRO DE SUBSTÂNCIAS HÚMICAS, 3, Santa Maria, 1999. Anais. Santa Maria: Universidade de Santa Maria, 1999. p.21-34.

LAVORENTI, A.; BURAUEL, P.; WAIS, A. \& FÜHR, F. Remobilization of bound anilazine residues in humic acids. In: INTERNATIONAL CONFERENCE OF THE INTERNATIONAL HUMIC SUBSTANCES SOCIETY, 9, Adelaide, 1998. Proceedings. Adelaide - Australia, University of Adelaide, 2001. p.541-547. 
LEONARD, R.A. Herbicides in surface waters. In: GROVER, R., ed., Environmental chemistry of herbicides. Boca Raton, CRC Publ. Co., 1988, p:45-89.

LEONARD, R.A. Movement of pesticides into surface waters. In: CHENG, H.H.. ed. Pesticides in the soil environment: Processes, impacts, and modeling. 2 ed. Madison, Soil Science Society of America, 1990. p.303-349.

LERCH, R.N.; BLANCHARD, P.E. \& THURMAN, E.M. Contribution of hydroxylated atrazine degradation products to the total atrazine load in Midwestern streams. Environmental Science and Technology , v.32, p.:40-48, 1998.

LERCH, R.N.; THURMAN, E.M. \& BLANCHARD, P.E. Hydroxyatrazine in soils and sediments. Enviromnental Toxicology and Chemistry, v.18, n.10, p.2161-2168, 1999.

LERCH, R.N.; THURMAN, E.M. \& KRUGER, E.L. Mixed-mode sorption of hydroxylated atrazine degradation products to soil: A mechanism for bound residue. Environmental Science and Technology, v.31p.1539-1546, 1997.

LIEBICH, J.; BURAUEL, P.; FÜHR, F. Microbiological degradation of nonextractable anilazine residues. Journal of Agricultural and Food Chemistry, v.47, p.3905$3910,1999$.

LINN, D.M. Sorption and degradation of pesticides and organic chemicals in soil. Madison, Soil Science Society of America. 1993. 260p. 
LU, X.X.; TAO, S.; CAO, J. \& PAWSON, R.W. Prediction of fish bioconcentration factors of nonpolar organic pollutants based on molecular connectivity indices. Chemosphere, v.39, p.987-999, 1999.

LYMAN, W.J.; REEHL, W.F. \& ROSENBLATT, D.H. Handbook of chemical property estimation methods: Environmental behavior of organic compounds. New York: McGraw-Hill, Inc., 1982. 752p.

MACALADY, D.L.; WOLFE, N.L. New perspectives on the hydrolytic degradation of the organophosphorothioate insecticide chlorpyrifos. Journal of Agricultural and Food Chemistry, v.18, p.1139-1147, 1983.

MA, L.; SELIM, H.M. Solute transport in soils under conditions of variable flow velocities. Water Resources Research, v.32, n.11, p.3277-3283, 1996.

MAGEE, B.R.; LION, L.W.; LEMLEY, A.T. Transport of dissolved organic macromlecules and their effect on the transport of phenanthrene in porus media. Environmental Science and Technology, v.25, p.323-331, 1991.

MAQUEDA, C.; MORILlO, E.; UNDABEYTIA, T.; MARTIN, F. Sorption of glyphosate and $\mathrm{Cu}(\mathrm{II})$ on a natural fulvic acid complex: mutual influence. Chemosphere, v.37, p.1063-1072, 1998.

MARTIN-NETO, L.; FERREIRA, J.A.; NASCIMENTO, O.R.; TRAGHETTA, D.G.; VAZ, C.M.P.; SIMÕES, M.L. Interação herbicidas e substâncias húmicas: estudos com espectroscopia e polarografia. In: ENCONTRO BRASILEIRO SOBRE 
SUBSTÂNCIAS HÚMICAS. 3. Santa Maria, 1999, Anais. Santa Maria: Grupo Brasileiro de substâncias húmicas, 1999. p.13-20.

MARTIN-NETO, L.; TRAGHETTA, D.G.; VAZ, C.M.P.; CRESTANA, S.; SPOSITO, G. On the interaction mechanisms of atrazine and hydroxyatrazine with humic substances. Journal of Environmental Quality, v.30, n.2, p.520-525, 2001.

MATSUMURA, F. Degradation of pesticides in the environment by microorganisms and sunlight. In: MATSUMURA, F. \& KRISHNA MURTI, C.R., ed., Biodegradation of pesticides. New York, Plenum Press, 1982. p.67-87.

MERKLE, M.G.; BOVEY, R.W. Movement of pesticides in surface water. In: GUENZI, W.D., ed., Pesticides in soil and water. Madison, Soil Science Society of America, 1974. p:99-106.

MERSIE, W.; SEYBOLD, C. Adsorption and desorption of atrazine, deethylatrazine, deisopropilatrazine, and hydroxyatrazine on levy wetland soil. Journal of Agriculture and Food Chemistry, v.44, p.1925-1929, 1996.

MERSIE, W.; SEYBOLD, C.; TSEGAYE, T. Movement, adsorption and mineralization of atrazine in two soils with and without switchgrass (Panicum virgatum) roots. European Journal of Soil Science, v.50, p.343-349, 1999.

MEYER-WINDEL, S.; LENNARTZ, B.; WIDMOSER, P. Bromide and herbicide transport under steady-state and transient flow. European Journal of Soil Science, v.50, p. 23-33, 1999. 
McCONNELL, J.S.; HOSSNER, L.R. pH-Dependent adsorption isotherms of glyphosate. Journal of Agricultural and Food Chemistry, v.33, p.1075-1078, 1986.

MEHLICH, A. Mehlich 3 soil test extractant: a modification of Mehlich 2 extractant. Communications in Soil Science and Plant Analysis, v.15, p.1409-1416, 1984.

MENDELSON, J. Round up: o herbicida mais vendido no mundo. The Ecologist, v.28, p.24-27, 1998.

MILES, C.J.; MOYE, H.A. Extraction of glyphosate herbicide from soil and clay minerals and determination of residues in soils. Journal of the Agricultural and Food Chemistry, v.36, p.486-491, 1988.

MONTEIRO, R.T.R. Degradação de pesticidas. In: MELO, I.S. \& AZEVEDO, J.L., ed., Microbiologia Ambiental. Jaguariuna: Embrapa, CNPMA, 1997. p.107-124.

MONTGOMERY, J.H. Agrochemicals, desk reference. 2 ed. Boca Raton, New York, Lewis Publishers, 1997. 656p.

MOREAU, C.; MOUVET, C. Sorption and desorption of atrazine, deethylatrazine, and hydroxyatrazine by soil and aquifer solids. Journal of Environmental Quality, v.26, p.416-424, 1997. 
MORRICA, P.; BARBATO, F.; DELlO IACOVO, R.; SECCIA, S.; UNGARO, F. Kinetics and mechanism of imazosulfuron hydrolysis. Journal of Agricultural and Food Chemistry, v.49, n.8, p.3816-3820, 2001.

MUSUMECI, M.R. Defensivos agrícolas e sua interação com a microbiota do solo. In: CARDOSO, E.J.B.N.; TSAI, S.M.; NEVES, M.C.P. Microbiologia do solo. Campinas: Sociedade Brasileira de Ciência do Solo, 1992. p.341-360.

NELSON, D.W.; SOMMERS, L.E. Total carbon, organic carbon and organic matter: In: PAGE, A.L. (Ed.). Methods of soil analysis, Part 2, 2ed. Madison: ASA, 1982, p.539-579.

NICHOLLS, P.H.; EVANS, A.A. Sorption of ionisable organic coumponds by fiel soils. Part 2: cations, bases and zwitterions. Pesticide Science, v.33, p.331-345,1991.

NIELSEN, D.R.; BIGGAR, J.W. Miscible displacement in soils: I. Experimental information. Soil Science Society of America Proceedings, v.25, n.1, p.1-5, 1961.

NIELSEN, D.R.; Van GENUCHTEN, M.Th.; BIGGAR, J.M. Water flow and solute transport processes in the unsaturated zone. Water Resource Research, v.22, p.89S-108S, 1986.

NKEDI-KIZZA, P.; BIGGAR, J.W.; SELIM, H.M.; Van GENUCHTEN, M.Th.; WIERENGA, P.J.; DAVIDSON, J.M.; NIELSEN, D.R. On the equivalence of two conceptual models for describing ion exchange during transport through an aggregated Oxisol. Water Resource Research, v.20, p.1123-1130, 1984. 
NOMURA, H.S.; HILTON, H.W. The adsorption and degradation of glyphosate in five Hawaii sugarcane soils. Weed Research, v.17, p.113-121, 1977.

OLSON, B.M.; LINDWALL, C.W. Soil microbial activity under chemical fallow conditions: Effects of 2,4-D and glyphosate. Soil Biology and Biochemistry, v.23, p.1071-1075, 1991.

PADGETTE, S. R.; KOLACZ, K. H.; DELANNAY, X.; RE, D.B.; LAVALLEE, B.J.; TINIUS, C.N.; RHODES, W.K.; OTERO, Y.I.; BARRY, G.F.; EICHHOLTZ, D.A. Development, Identification, and Characterization of a Glifosato-Tolerant Soybean Line. Crop Science, v. 35, p. 1451-1461, 1995.

PANG, L.P.; CLOSE, M.E.; WATT, J.P.C.; VINCENT, K.W. Simulation of picloram, atrazine, and simazine leaching through two New Zealand soils and two groundwater using hydrus-2d. Journal of Contaminant Hydrology, v.44, p.19-46, 2000.

PAPINI, S.; ANDRÉA, M. Enhanced degradation of metalaxyl in agricultural soils of São Paulo State, Brazil. Pesquisa Agropecuária Brasileira, v.36, n.1, p.1-5, 2001.

PARKER, J.C.; Van GENUCHTEN, M.Th. Determining transport parameters from laboratory and field tracer experiments. Bulletin 84-3, Virginia Agricultural Experimental Station, Blacks-burg, VA. 1984. 59p.

PEIXOTO, M.F.S.P.; LAVORENTI, A.; REGITANO, J.B.; TORNISIELO, V.L. Degradação e formação de resíduos ligados de ${ }^{14} \mathrm{C}$-atrazina em Latossolo Vermelho Escuro e Glei Húmico. Scientia Agrícola, v.57, p.147-151, 2000. 
PEREIRA, W.E.; ROSTAD, C.E. Occurrence, distributions, and transport of herbicides and their degradation products in the lower Mississippi River and its tributaries. Environmental Science and Technology, v.24, p.1400-1406, 1990.

PICCOlO, A.; CElANO, G.; ARIENZO, M.; MIRABELlA, A. Adsorption and dessorption of glyphosate in some Europeans solis. Journal of Environmental Science Health, v.6, p.1105-1115, 1994.

PICCOLO, A.; CELANO, G.; CONTE, P. Adsorption of glyphosate by humic substances. Journal of the Agricultural and Food Chemistry, v.44, p.2442-2446, 1996.

PIERZYNSKI, G.M.; SIMS, J.T.; VANCE, G.F. Soils and environmental quality. Boca Raton, Lewis publishers: CRC Press, 1994. 313p.

PIGNATELLO, J.J.; FRANCIS, J.F.; HUANG, L.Q. Elution of aged and freshly added herbicides from a soil. Environmental Science and Technology, v.27, n.8, p.15631571, 1993.

PRATA, F.; LAVORENTI, A. Comportamento de herbicidas no solo: Influência da matéria orgânica. Revista Biociências, v.6, p.17-22, 2000.

PRATA, F.; LAVORENTI, A.; REGITANO, J.B.; TORNISIELO, V.J. Degradação e adsorção de diuron em solos tratados com vinhaça. Revista Brasileira de Ciência do Solo, v.24, p.217-223, 2000a. 
PRATA, F.; LAVORENTI, A.; REGITANO, J.B.; TORNISIELO, V.L. Influência da matéria orgânica na sorção e dessorção do glifosato em solos com diferentes atributos mineralógicos. Revista Brasileira de Ciência do Solo, v.24, p.947-951, 2000b.

PRATA, F.; LAVORENTI, A.; REGITANO, J.B.; TORNISIELO, V.L. Degradação e sorção de ametrina em dois solos com aplicação de vinhaça. Pesquisa Agropecuária Brasileira, v.36p.975-981, 2001.

PRINTZ, H.; BURAUEL, P.; FÜHR, F. Influence of crop residues on degradation, formation of bound residues and transport of methabenzthiazuron in soil. In: WALKER, A. Pesticide movement to water. England: Coventry, 1995. p.53-58.

QARE-ABU, A.W.; DUNCAN, H.J. Photodegradation of the herbicide EPTC and the safener dichlormid, alone and in combination. Chemosphere, v.46, n.8, p.11831189, 2002.

QUEIROZ, B.S.R. Biodergradação de ${ }^{14} \mathrm{C}$-atrazina em condições semi-controladas. Piracicaba, 1997. 95p. Dissertação (Mestrado) - Escola Superior de Agricultura "Luiz de Queiroz", Universidade de São Paulo.

QUINN, J.P.; PEDEN, J.M.M.; DICK, R.E. Glyphosate tolerance and utilization by microflora of soils treated with the herbicide. Applied Microbiology and Biotechnology, v.29, p.511-516, 1988.

RACKE, K.D. Pesticide in the soil microbial ecosystem. In: RACKE, K.D.; COATS, J.R., ed., Enhanced biodegradation of pesticides in the environment. Washington: ACS, 1990. p.1-12. (ACS Symposium Series, 426). 
RAIJ, B.; QUAGGIO, J.A. Métodos de análise de solos para fins de fertilidade. Campinas: IAC, 1983. 31p. (IAC. Boletim Técnico, 81).

REGITANO, J.B.; BISCHOFF, M.; LEE, L.S.; REICHERT, J.M.; TURCO, R. Retention of imazaquin in soils. Environmental and Toxicologycal Chemistry, v.16, p.397-404, 1997.

REGITANO, J.B.; PRATA, F.; DIAS, N.N.P.; LAVORENTI, A.; TORNISELO, V.L. Sorção-desorção do fungicida clorotalonil em solos com diferentes teores de matéria orgânica. Revista Brasileira de Ciência do Solo, v.26, p.267-274, 2002.

REGITANO, J.B.; PRATA, F.; ROCHA, W.S.D.; TORNISIELO, V.L.; LAVORENTI, A. Imazaquin mobility in tropical soils in relation to soil moisture and rainfall timing. Weed Research, v.42, p.1-8, 2002b.

ROBERTS, T.R.; HUTSON, D.H.; LEE, P.W.; NICHOLLS, P.H.; PLIMMER, J.R. Metabolic pathways of agrochemicals. Part 1: Herbicides and plant growth regulators. London: The Royal Society of Chemistry, 1998. p.386-400.

ROBERTS, T.R.; HUTSON, D.H. Metabolic pathways of agrochemicals. Part 2: Insecticides and fungicides. United Kingdom: The Royal Society of Chemistry, 1999. p.1380-1384.

ROCHA, A.A. Sorção, dessorção e degradação do herbicida ${ }^{14}$ C-diclosulam em um Latossolo Vermelho sob sistemas de plantio convencional e direto. Piracicaba, 1999. 76p. Dissertação (Mestrado) - Escola Superior de Agricultura "Luiz de Queiroz". 
ROCHA, W.S.D.; ALLEONI, L.R.F.; REGITANO, J.B.; CASAGRANDE, J.C.; TORNISIELO, V.L. Influência do pH na sorção de imazaquin em um Latossolo Vermelho acriférrico. Revista Brasileira de Ciencia do Solo, v.24, p.649-655, 2000.

ROCHA, W.S.D.; REGITANO, J.B.; PRATA, F.; ALLEONI, L.R.F.; TORNISIELO, V.L. Lixiviação de imazaquin em Latossolo ácrico. In: CONGRESSO BRASILEIRO DE CIÊNCIA DO SOLO. 28, Londrina, 2001. Anais. Londrina, Sociedade Brasileira de Ciência do Solo, 2001, p.338

RODRIGUES, B.N.; ALMEIDA, F.S. Guia de herbicidas. Londrina: IAPAR. 1995. 675 p.

ROSEN, J.D. The photochemistry of several pesticides. In: MATSUMURA, F.; BOUSH, G.M. \& MISATO, T., ed., Environmental toxicology of pesticides. New York: Academic Press, 1972. p:435-447.

ROY, D.N.; KONAR, S.K.; BANERJEE, S.; CHARLES, D.A.; THOMPSON, D.G.; PRASAD, R. Percistence, movement, and degradation of glyphosate in selected Canadian Boreal forest soils. Journal of the Agricultural and Food Chemistry, v.37, p.437-440, 1989.

RUEPPEL, M.L.; BRIGHTWELL, B.B.; SCHAEFER, J.; MARVEL, J.T. Metabolism and degradation of glyphosate in soil and water. Journal of the Agricultural and Food Chemistry, v.25, p.517-528, 1977.

SABADIE, J. Nicosulfuron: Alcoholysis, chemical hydrolysis, and degradation on various minerals. Journal of Agricultural and Food Chemistry, v.50, n.3, p.526-531, 2002. 
SADEGHI, A.M.; ISENSEE, A.R. Alachlor and cyanazine persistence in soil under different tillage and rainfall regimes. Soil Science, v.162, p.430-438, 1997.

SADEGHI, A.M.; ISENSEE, A.R.; SHELTON, D.R. Effect of tillage age on herbicide dissipation: A side-by-side comparison using microplots. Soil Science, v.163, n.11, p.883-890, 1998.

SAWHNEY, B.L.; BROWN, K. Reactions and movement of organic chemicals in soils. Madison, Soil Science Society of America, 1989, 474p.

SCHUZ, R. Comparison of spray drift and runoff related input of azinphos-methyl and endosulfan from fruit orchards into the Lourens river, South Afric. Chemosphere, v.45, p.543-551, 2001.

SENESI, N. Binding mechanisms of pesticides to humic substances. The Science Total of Environment. v.123, p.63-76, 1992.

SHELTON, D.R.; SADEGHI, A.M.; ISENSEE, A.R. Effect of tilagge on atrazine bioavailability. Soil Science, v.163, n.11, p.891-896, 1998.

SMITH, A.E.; AUBIN, A.J. Degradation of ${ }^{14}$ C-glyphosate in Saskatchewan soils. Bull. Enviromnental Contaminant Toxicology. 50:499-505, 1993.

SMITH, J.H.; MABEY, W.R.; BOHONOS, N; HOLT, B.R.; LEE, S.S.; CHOU, T.W.; BOMBERGER, D.C.; MILL, T. Environmental pathways of selected chemicals in freshwater systems. Part II. Laboratory studies. EPA-600/7-78-074. USEPA, Athens, GA. 1978. 
SKIPPER, H.D.; VOLK, V.V. Biological and chemical degradation of atrazine in three Oregon soils. Weed Science, v.20, n.4, p.344-347, 1972.

SOLOMONS, T.W.G. Química orgânica I. Ed. 6. Livros Técnicos e Científicos Editora. Rio de Janeiro. 1991. 436p.

SOMASUNDARAM, L.; COATS, J.R. Influence of pesticide metabolites on the development of enhanced biodegradation. In: RACKE, K.D.; COATS, J.R., ed., Enhanced biodegradation of pesticides in the environment. Washington: ACS, 1990. p.128-140. (ACS Symposium Series, 426).

SPARKS, D.L. Kinetics of soil chemical processes. London. Academic Press. 1989. 210p.

SPRANKLE, P.; MEGGITT, W.F.; PENNER, D. Adsorption, mobility, and microbial degradation of glyphosate in the soil. Weed Science, v.23, p.229-234, 1975.

STEEN, W.C.; PARIS, D.F.; BAUGHMAN, G.L. Contaminants and sediments. In: BAKER, R.A., ed., Contaminants and sediments. Michigan: Ann Arbor Science Publications, 1980. p.477-482.

STOUGAARD, R.N; SHEA, P.J.; MARTIN, A.R. Effect of soil type and $\mathrm{pH}$ on adsorption, mobility and efficacy of imazaquin and imazethapyr. Weed Science, v.38, p.67-73, 1990.

SUN, N.T. Mathematical modeling of groundwater pollution New York. SpringerVerlag. 1996, 377p. 
TAN, K.H. Principles of soil chemistry. 2. ed, New York, Basel, Hong Kong. 1993. $362 \mathrm{p}$.

TAYLOR, A.W.; SPENCER, W.F. Volatilization and vapor transport processes. In: CHENG, H.H.. ed. Pesticides in the soil environment: Processes, impacts, and modeling. 2 ed. Madison, Soil Science Society of America, 1990. p.213-270.

THURMAN, E.M.; GOOLSBY, D.A.; MEYER, M.T.; KOLPIN, D.W. Herbicides in surface waters of the midwestern United States: the effect of spring flush. Environmental Science and Technology, v.25, p.1794-1796, 1991.

THURMAN, E.M.; MEYER, M.T.; MILLS, M.S.; ZIMMERNAN, L. R.; PERRY, C.A. Formation and transport of deethylatrazine and deisopropylatrazine in surface water. Environmental Science and Technology, v.28, p.2267-2277, 1994.

TORIDE, N.; LEIJ, F.J.; van GENUCHTEN, M.T. The CXTFIT code for estimating transport parameters from laboratory or field tracer experiments: Version 2.0. Research Report n.137, U.S. Salinity Laboratory of Agricultural Research Service. USDA. Riverside, California. 1995. 121p.

TRIPLETT, G.B.; CONNER, B.J.; EDWARDS, W.M. Transport of atrazine and simazine in runoff from conventional and no-tillage corn. Journal of Environmental Quality, v.7, p.77-84, 1978.

U.S. EPA. 1986. Pesticides in ground water: Background Document, office of groundwater protection. Washington, DC, 1986. 1315p. 
Van GENUCHTEN, M.Th.; WAGENET, R.J. Two-site/two-region models for pesticide transport and degradation: Theoretical development and analytical solutions. Soil Science Society of America Journal, v.53, n.5, p.1303-1310, 1989.

Van GENUCHTEN, M.Th.; WIERENGA, P.J. Mass transfer studies in sorbing porous media, I, Analytical solutions. Soil Science Society of America Journal, v.40, p.473-481, 1976.

Van GENUCHTEN, M.Th.; WIERENGA, P.J.; O'CONNOR, G.A. Mass transfer studies in sorbing porus media, III. Experimental evaluation with 2,4,5-T. Soil Science Society of America Journal, v.41, p.278-285, 1977.

VEREECKEN, H.; JAECKEL, U.; ESSER, O.; NITZSCHE, O. Solute transport analysis of bromide, uranium and $\mathrm{LiCl}$ using breakthrough curves from aquifer sediment. Journal of Contaminant Hydrology, v.39, p.7-34, 1999.

VEREECKEN, H.; NITZSCHE, O.; SCHULZE, M. Analysis of the transport of hydrophobic organic xenobiotics in the presence of dissolved organic carbon using soil column experiments. In: CLAPP, C.E.; HAYES, M.H.B.; SENESI, N.; BLOON, P.R.; JARDINE, P.M. Humic substances and chemical contaminants. Madison, Soil Science Society of America, 2001. p:449-470.

VETTORI, L. 1969. Métodos de análise do solo. 24p. Ministério da Agricultura, Div. Pedologia e Fertilidade do Solo. (Boletim Técnico, 7)

VUlliET, E.; EMMELIN, C.; GRENIER-LOUSTAllOT, M.F.; PAISSE, O.; CHOVELON, J.M. Simulated sunlight-induced photodegradation of triasulfuron and cinosulfuron in aqueous solution. Journal of Agricultural and Food Chemistry, v.50, n.5, p.1081-1088, 2002. 
WARDLE, D.A.; PARKINSON, D. effects on three herbicides on soil microbial biomass and activity. Plant Soil, v.122, p.21-28, 1990.

WOLFE, N.L.; MINGELGRIN, U.; MILLER, G.C. Abiotic transformations in water, sediments, and soil. In: CHENG, H.H.. ed. Pesticides in the soil environment: Processes, impacts, and modeling. 2 ed. Madison, Soil Science Society of America, 1990. p.103-168.

WOODBURN, K.B.; DELFINO, J.J.; RAO, P.S.C. Retention of hydrophobic solutes on reversed-phase liquid chromatography supports: correlation with solute topology and hydrophobicity indices. Chemosphere, v.24, p.1037-1046, 1992.

ZEPP, R.G.; WOLFW, N.L.; GORDON, G.L. \& BAUGHMAN, G.L. Dynamics of 2,4D esters in surface waters. Hydrolysis, photolysis, and vaporization. Environmental and Science Technology, v.9, p.1144-1150, 1975. 